\title{
Kernos
}

Revue internationale et pluridisciplinaire de religion grecque antique

18 | 2005

Varia

\section{Epigraphic Bulletin for Greek Religion 2002 (EBGR 2002)}

\section{Angelos Chaniotis et Joannis Mylonopoulos}

\section{(2) OpenEdition}

\section{Journals}

Édition électronique

URL : http://journals.openedition.org/kernos/1548

DOI : 10.4000/kernos. 1548

ISSN : 2034-7871

\section{Éditeur}

Centre international d'étude de la religion grecque antique

\section{Édition imprimée}

Date de publication : 1 janvier 2005

Pagination : 425-474

ISSN : 0776-3824

\section{Référence électronique}

Angelos Chaniotis et Joannis Mylonopoulos, « Epigraphic Bulletin for Greek Religion 2002 (EBGR

2002) », Kernos [En ligne], 18 | 2005, mis en ligne le 08 juillet 2011, consulté le 15 septembre 2020

URL : http://journals.openedition.org/kernos/1548 


\section{Epigraphic Bulletin for Greek Religion 2002 (EBGR 2002)}

With the 15th issue of the Epigraphic Bulletin for Greek Religion we present only the first part of a selection of epigraphic publications of the year 2002. The necessity to coordinate the publication of the $E B G R$ with the edition of the $S E G$, but also the rather limited space available in this volume of Kernos, has not made the presentation of the entire epigraphic harvest of 2002 in this issue possible; but we have filled some of the gaps from earlier issues (especially EBGR 2000 and 2001). As in earlier bulletins, we have included in our selection also texts that contribute to the understanding of the development of Greek religion in a broader cultural context (Oriental cults, Judaism, and Early Christianity). Among the books and articles summarized below we single out the new corpora of Delphi (88, documents concerning the administration of the Amphictyony), Philippi (121), and Kibyra (28), two important contributions to the understanding of 'Orphic' concepts and rituals ( $\mathbf{8}$ and 124), an intriguing analysis of the ruler cult of Antiochos III and Laodike in Iasos (108), treatments of magical texts as a source of cultural and social history (44-45; cf. the analysis of the combination of cursing and blessing in a grave inscription: 54), comments on the competition among cults in the Imperial period (19 and $\mathbf{7 4}$ ), and a series of studies dedicated to the ambiguities in the use of a religious vocabulary and to the hazy borders among religious groups in the Imperial period and especially in Late Antiquity (13, 20-21, and 149). Many new inscriptions illuminate facets of worship and religious beliefs; we mention, e.g., a new epithet of Poseidon (Potbaterios, sc. Prosbaterios) in Delphi (65), a letter of Hadrian to Naryx which alludes to the local myths and in particular to the myth of the Lokrian Aias (115), a new lex sacra found in Samos, but originally from Erythrai, concerning the cult of the Korybantes (62, cf. 32), a new leasing document from Amos in Karia with a clause which seems to allude to the periodical cleaning of a sacred grove on the occasion of a sacrifice (11), oracular inquiries from Miletos, one of which may be a new attestation of imperial mysteries (41), an epitaph from Yehilova with a list of offerings to be made to the goddess Ma in Komana (6), a very important inscription from Hierapolis which quotes a sacred regulation of the cult of Zeus (126), and inscriptions from Asia Minor that provide information concerning the funerary cult (e.g., 117 and 119). With regard to the evolution of concepts of divinity, we draw attention to the increasing number of dedications which do not name the deity, but only its attributes - e.g., "the God under the Earth" in Philippi (121), "the Just Gods" and "the Lord, the God Above" in Kibyra (28), and the "divinity with the many forms/images" in Stratonikeia (131). The principles explained in Kernos, 4 (1991), p. 287-288 and Kernos, 7 (1994), p. 287 also apply to this issue. Abbreviations which are not included in the list of abbreviations are those of L'Année Philologique and J.H.M. STRuBBE (ed.), Supplementum Epigraphicum Graecum. Consolidated Index for Volumes XXXVI-XLV (1986-1995), Amsterdam, 1999, as well as of later volumes of the $S E G$. If not otherwise specified, dates are B.C. We are very much obliged to Dr. James Cowey for improving the English text. [AC] 


\begin{abstract}
Abbreviations
$B I W K$

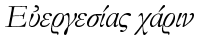

Festschrift Deininger

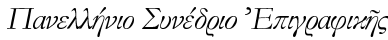

Zona Archeologica

Problemi della chora coloniale

G. PETZL, Die Beichtinschriften Westkleinasiens (EA, 22), Bonn, 1994

T. DERDA - J. URBANIK - M. WeCOWski (eds), Eúcgycoías záow. Studies Presented to Benedetto Bravo and Ewa Wipszycka by their Disciples, Warsaw, 2002.

N. EHRHARDT - L.-M. GÜNTHER (eds), Widerstand Anpassung - Integration. Die griechische Staatenwelt und Rom. Festschrift für Jürgen Deininger zum 65. Geburtstag, Stuttgart, 2002.

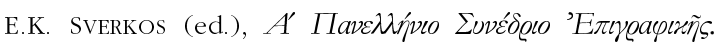

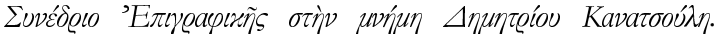

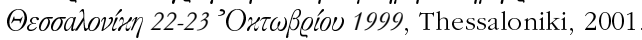

S. BuZZI - D. KÄCH - E. KISTLER - E. MANGO - M. PALACZYK - O. STEFANi (eds), Zona Archeologica. Festschrift für Hans Peter Isler zum 60. Geburtstag, Bonn, 2001.

Problemi della chora coloniale dall' Occidente al Mar Nero. Atti del quarantesimo convegno di studi sulla Magna Grecia, Taranto 29 settembre-3 ottobre 2000, Taranto, 2001.
\end{abstract}

\title{
Select Topics
}

Geographical areas (in the sequence adopted by $S E G$ )

Attica: 31. 42. 47. 51. 56. 79. 83-86. 134. 137. 140. 144. 155. 158. Corinthia: Corinth: 69; Isthmos: 69. Epidauria: Epidauros: 14. Lakonia: Sparta: 29. 40. 123. 160. Messenia: Messene: 118. 145. Arkadia: Gortyn: 135; Megalopolis: 87. 138. Elis: Olympia: 142. Boiotia: Akraiphia: 153; Chaironeia: 114; Oropos: 75. 140. Delphi: 65. 78. 88. 92. 97. 130. 140. 142. Phokis: Antikyra: 109. Eastern Lokris: Naryx: 115. Western Lokris: Naupaktos: 133. Thessaly: 26; Atrax: 150; Gonnoi: 150; Larisa: 59. 150; Phalanna: 150; Pherai: 38. Epeiros: Dodona: 135. Macedonia: Dion: 112; Kassandreia: 143; Pella: 27; Philippi: 11. 120-122. 148; Sane: 147; Thessalonike: 1. 73 113. 139. Thrace: 33. 136. Moesia: Histria: 3; Kallatis: 152. North Shore of the Black Sea: 13. 152; Olbia: 14. 16. 152. Delos: 24. 29. 31. 60. 132. Rhodes: Kamiros: 99. 116; Lindos: 31. 34. Lesbos: 64. 70-71. Thera: 22-23. Kos: 34. 77. Samos: 31. 61. Samothrake: 55. 72. Euboia: Eretria: 7. 76. 140; Zarax: 24. Crete: 9. 23. 137. 137bis ; Aptera: 102; Chersonesos: 80; Gortyn: 94-95. 100; Idaean Cave: 18. Itanos: 22. Italy: Metapontion: 154; Rome: 68. Sicily: 4; Eryx: 51; Messana: 141; Selinous: 93. Asia Minor: 30; Karia: Alabanda: 125; Amos: 10. Aphrodisias: 20-21; Iasos: 91. 108; Knidos: 34; Labraunda: 30; Lagina: 131; Stratonikeia: 67. 131; Panamara: 131. Ionia: Ephesos: 30. 51. 74; Erythrai: 32. 61; Miletos: 31. 41. 51; Priene: 51. Lydia: 2. 119. 129; Hypaipa: 62. Aiolis: Ilion: 125. Mysia: Pergamon: 105-107. Bithynia: 117; Klaoudioupolis. 98. Pontos: Sinope: 36; Phrygia: 129; Aizanoi: 30. 90; Dorylaion 48; Hierapolis: 126-127. Pisidia: Antiocheia: 39; Sibidounda: 13 Termessos: 13. 17; Lykia: Kibyra: 28; Limyra: 101; Myra: 101. Kilikia: Aigeai. 141. Kappadokia: Komana: 6. Cyprus: 22. Syria: Antiocheia: 82; Edessa: 12; Kanatha: 5. 43. Jordan: Hawara: 110; Philadelphia: 50. Egypt: 81; Alexandria: 54. Kyrenaika: Kyrene: 34-35. 51. 111 
account: 88. 97

aesthetic, in rituals: 88 ; see also decoration

agon: 35. 57. 88. 94. 105. 123. 140. 142. 159; agonistic festival, see festival

Aischylos: 34

Alexander of Abonouteichos: 19

altar: 3. 36. 41. 48. 60. 76. 101. 108. 110. 117. 131. 138. 150

amphictyony: 88. 115

amulet: 44-45; see also gem

animals: bull: 6; cow: 6; eagle: 48. 52; goat: 6; horse: 6; ox: 48; ram: 6; swallow: 6; see also sacrificial animal

architecture, religious: 60

association, cult: 22. 29. 60. 77. 89. 105. 112. 121. 136-137

asylia: 88. 130

baetyl: 48

banquet: 28. 42. 61. 69. 131

bath, ritual: 88.126

birthday, of a divinity: 74. 131; of queen Laodike: 108

burial: 8; prohibition against b.: 10; see also funerary cult

calendar: 117 (in Bithynia); sacrificial: 42. 83-86

cave: 9

Christianity: 20-21. 120. 149

chthonic deity: 49. 54. 61

'confession inscriptions': 129

creation: 12

crown: 48. 88. 105

cult, competition among c.: 19. 74; foundation of c.: 2. 19. 48. 131; c. founder: 48; c. transfer: 22. 117 (parentalia, rosalia). 121; c. of Roman magistrates: 146; see also emperor cult, hero cult, ruler cult, festival, ritual

cult personel: agonothetes: 14. 69. 87-88. 91; archiepimenios: 105; archieranistes: 77; archiereia of the emperor cult in Asia: 28; in a city: 28; archiereus of the Attalids: 105; archiereus of the emperor cult in Achaia: 88; in Asia (Asiarches): 28. 104. 156; in Lykia (Lykiarches): 28; in a city: 71. 131; archiereus ton Ionon: 63; archimagos: 62; dendrophoros: 136; epimenios: 77 ; hiereia: 14 . 28. 61. 108. 111 126. 131 ; hiereus: 6. 14. 28. 63. 70. 77. 105. 108. 126-127. 131. 136. 139; hierokeryx: 88; hieromnemon: 10. 88; hierones: 64; hieronomos: 105; hierophantes: 42; hieropoios: 137; hieros pais: 88; hieros: 90; hierothytes: 138; hydragos: 29; hyphydragos: 29; kleidophoros: 131; kleidouchos: 77; magos: 62; meter dendrophoron: 136: neokoros: 28. 121; neopoies/neopoios: 91. 97; pyrouchos: 17; theekolos: 115; zakoros: 131; see also priesthood, Greek terms

curse: 44. 54. 129; in an oath: 28; curse tablet: 49. 68; see also funerary imprecation, magic

daimon: 131

decoration, of sacred objects, places: 61.88

dedication: 3. 60; of foot: 13; of money: 24 (thrown in fountains). 79; of reliefs: 48; of sacrificial implements: 28; of statues: 28. 39. 126; of a temple: 113. 151 
dedication, by priest/priestess: 17. 150; by priest after his term of office: 3 ; by soldiers: 3. 22. 50. 59; in commemoration of an athletic victory: 92 ; for the safe return from a journey: 48. 58; for rescue: 58-59; for the victory of an emperor: 3 ; for the well-being of the family: 48; for the well-being of an emperor: 80; thankgiving: 28. 58-59, 78. 110; upon divine command:3. 48. 70. 117; funded with sacred money: 127 ; joint dedication to healing god and doctor: 28 ; reciprocity in dedicatory practices: 154 , regulation concerning d.: 88

deification, of Antinoos: 98; of Drusus: 131

deities: Agathos Daimon: 77. Amphiaraos: 75. Aphrodite: 73. 77; Epekoos 3; Eudie 77; Hilara 4; Pontia 33. Apollon: 28. 33. 77. 98. 121. 125. 131. 147. 151; Chereusieideus 28; Chresterios 58; Delios 25; Delphinios 14; Didymeus 31. 41. 131 (?); Ietros 3. 14; Karneios 35; Klarios 52-53; Komaios 121; Mousagetes 150; Nisyreites 58; Oulios 152; Pholeuterios 152; Pythios 78; Samnaios 10. Ares: 3. 117. Arete: 28. Artemis: 3. 17. 121. 131. 150-151; Brauronia 144; Diktynnaia 109; Eleithya 109; Ephesia 30. 74; Hyakinthotrophos 34; Katagogis 51; Opitais 121; Philoparthenos 17; Tauropolos17; Thermia 70. Asklepios: 3. 8. 15. 28. 33. 58. 88. 98. 155; Poliouchos 141; Soter 141. Athena: 3. 12. 40. 58. 77. 131. 155; Lindia 31. 77; Pronaia 88. Demeter: 3. 8. 14. 17. 28. 54. 70. 98. Despoina: 100 (?). Dionysos: 3. 8. 98. 112. 120-121. 128. 136; Bakchos 77; Botrys 121; Kadmeios 88; Katagogios 51. Dioskouroi: 28-29. 33; Soteres 3. Dodekatheon: 126. Eileithyia: see Artemis. Eirene: 3. 131. En(n)odia: 26. 38; Korroutara 26 (?). Eueteria: 70. Eumelios: 77. Ge: 117; Karpophoros 28 (?). Glykon Neos Asklepios: 19. Hades: 33. Hekate: 3. 16. 52. 131. Helios: 8. 58. 77. 117. Hephaistos: 33. Hera: 12. 31. 111. 117; Ourania 77. Herakles: 3. 8. 28 (Theos). 35.58 60. 145. 154. Hermes: 9. 35. 60. 77. 98. 145; Chthonios 150; Enagonios 88; Eriounios 9; Pantokrator 9; Polykarpos 95. Homonoia: 28. 39. Hygeia: 141. Kore: 14. 135. Korybantes/Kyrbantes: 32. 62. Leto: 3. Mes: 28; Axiottenos 58; Ouranios 13. Meter Theon: 3. 14. 121. Maia: 60. Moira(i): 3. 8. Mousai: 3. 35. 41. 112. Nemesis: Aniketos 121. Nike: 52. Ouranos: 117. Pan: 121; Eubodos 58. Parthenos: 121. Persephone: 3. 54. Phorkys: 152. Plouton: 49. 121. Ploutos: 3. Poseidon: 58. 69. 121. 160; Aisios 29; Asphaleios 77; Prosbaterios 65. Selene: 117 . Semnai Theai: 86. Sozon: 58. Thea: Almopia 121; Rhome 28. Theion: Polymorphon 131. Theoi: Dikaioi 28; 28; Dodeka 126. 134; Hosioi 28; Katachthonioi 33. 90; Megaloi 28. 49. 55; Motaleon 127; Patrioi 126. Theos: Ano 28; Epekoos 20; Hypogaios 121; Hypsistos 13. 36. 58. 120. 131. Tyche: 28. 59 (?). Zeus: 8. 12. 52. 58. 87. 98. 117. 119. 121. 126-127. 131. 151; Agoraios 76; Antigonaos 2; Atabyrios 77; Bronton 48; Chrysaorios 131; Hyetios 77; Hypsistos 12. 77. 113; Karios 127; Karpophoros 28 (?); Megas 28; Megistos 48; Megistos Kapitolios 110; Melosios 158; Na(i)os 135; Nemeos 85; Olympios 50. 126; Panamaros 131; Pharnavas 6; Pyrgenos 48; Sarapis 110; Solymeus 17; Soter 28. 77. 118; of Thymnasa: 6; Tropaios 105

deities, Anatolian: Kakasbos: 28 (Theos); Egyptian: 11. 22. 58. 121. 131. 139. 148; Oriental: Anaitis/Anahita: 6. 62; Astarte: 77; Jupiter Dolichenus: 3; Kybele: 3. 11 136; Mithras: 3; Sabazios: 28. 33; Theos Rabbou: 5. 43; Roman: Iuppiter Optimus Maximus: 33; Silvanus: 33. 120; Thracian: Bendis: 117; Rider God: 3. 33; Souregethes: 121

deities, assimilated with a deceased person: 73 ; patrons of agriculture: 48. 126; of the agora: 95; of children: 26; of fertility: 95; of livestock: 77; of potters: 12; of seafaring: 65; periodical return: 51 
double axe: 28

Derveni Papyrus: 8

Eleusinian mysteries: 155

emperor cult: 11. 28. 41. 63. 69-71. 77. 101. 104. 122. 126. 131. 141. 143. 150. 156

epiphany: 34

eschatology: 28. 46. 99. 124

fasting: 14

festival, establishment of: 34; funding of: 91.127

festivals, agons: Alexandreia: 63 (Ionia); Amphiaraia: 140 (Oropos); f. in Athens: 83; f. of the Cretan Koinon: 94; Dia: 126 (Hierapolis); Didymia: 123 (Miletos); Dionysia: 88 (Chios). 89 (Eretria). 91 (Iasos). 125 (Alabanda); Eleutheria: 138 (Plataiai); Eurykleia: 123 (Sparta); Genesia: 86 (Athens); Heraia: 131 (Lagina); of the Ionian Koinon: 63; Isthmia: 69. 123. 140; Kaisareia: 28 (Kibyra). 123 (Sparta); Katagogia: 51; Kornelia: 123; Nemea: 85. 94; Nikephoria: 106-107 (Pergamon); Nyktophylaxia: 132 (Delos); Olympia: 94 (Smyrna). 123 (Olympia?). 126 (Hierapolis). 142 (Olympia); Panathenaia: 137. 140 (Athens); Panionia: 63; Ptolemaia: 88 (Alexandria); Pythia: 88. 123 (Delphi); Rhomaia: 140 (Oropos); Soteria: 88 (Delphi); Thesmophoria: 132

fire: 8.17

foot, dedication of: 13

funerary cult: $6.28 .77 .90 .99 .114 .117 .119 .121 .128 .138 .143 ; \mathrm{f}$. imprecation: 6. 90

117. 149; protection of grave: 17. 90; see also burial, heroization, Greek terms

gem: 52-53

godfearers: 13.20

grove: 10

gymnasium: 28. 35. 94. 145

hair, offering of: 108. 131

healing: 28. 58. 74; cult: 19

Heraclit: 8

hero cult: 42; Achilleus: 14. 16; Heros Auloneites: 120-121; Heros: 121; Heros Epekoos: 121; Kar: 67; heroization: 8. 27-28. 48. 73. 90. 102. 138. 153

homosexuality: 23

hymn: 9; hymnodos: 28; hymnody: 19

identity, religuous: 19

inauguration, of magistrates: 108

initiation: 23. 61. 124

inventories: $24.30-31.79 .88$

inviolability: 30 . 88 ; see also asylia

invocation: 48

Jews, Judaism: 13. 20-21. 82. 120-121. 149. 157

justice, divine: 8. 28. 54. 117. 129

labrys: 21

land, sacred: 88

Late Antiquity, paganism in: 20-21 
lex sacra: 32. 34. 42. 61. 83. 88.93.116.126. 131

libation: 9. 126-127

magic: 44-45. 49. 52-54. 68; cf. amulet, curse, gem

manslaughter: 88.93

manumission: 6. 13.72 (?). 114

marriage: 119

mind, holiness of: 15

mystery cult: 19. 41 (in connection with the emperor cult?). 72.98 (in connection with Antinoos). 121. 128. 136. 155

myth: Aias: 115; mythical ancestry: 98; see also hero

names, as reflection of religious beliefs: 21; theophoric n.: 14 (Metrophanes, priest of Meter?). 28 (Menophantos, Menis, and cult of Mes). 77 (Eumeliodoros; Hermeios founder of the Hermaistai). 81 (in Egypt); theophoric names of tribes: 98 night, celebrations: 132; see also pannychis

number, religious significance of: 6

Nyktophylaxia: 132

oath: 129; amphictyonic: 88 ; citizen: 28 ; ephebic: 28 ; treaty 28

oracle: 19. 41. 88. 119. 130-131; alphabetical: 28

'Orphics': 8. 46. 124. 128. 152

paganism in Late Antiquity: 21

Panathenaic amphora: 7

pannychis: 127

papyri, magical: 45

Parmenides: 152

personification: 7; see also deities, s.vv. Arete, Eirene, Eueteria, Homonoia

pilgrimage: 9; protection of pilgrims: 88

Pindar: 46

politics, and religion: 30.75 .108

prayer: 28.54

priest, priesthood; couples of priests: 28. 104. 131; accumulation of priesthoods: 28. 131; election of: 108; families of p.: 104; p. for life: 28. 32. 70; list of p.: 111; perquisites: 32. 61. 83; prohibition of reelection: 108; sale of: 30. 32. 61

private, cult: 32 . 41 ; p. sacrifice: 61

procession: 86.108 .131 ; processional chariot: 140; processional way: 74

Prometheus: 12

protection, of pilgrims: 88

purification: 61. 93. 126; purity: 15

reciprocity, in the relation between mortals and gods: 154

rituals; aesthetic of: 88 ; interruption because of war: 88 ; cf. s.v. banquet, bath, fasting, hair offering, inauguration, initiation, libation, Nyktophylaxia, oath, pannychis, prayer, purification, sacrifice

roses, offering of: 126

ruler cult, Hellenistic: 22. 105. 108. 121; see also emperor cult 
sacrifice: 28. 32. 42. 48. 56. 61-62. 69. 83. 105. 108. 126. 131. 137-138; funding of s.: 126. 137; bloodless: 83; sacrificial animal: 64 (purchase). 83. 116. 131. 138; sacrificial meat: 88 (distribution). 121

sacrilege: 88

salvation: 58

sanctuaries: 30. 137bis; boundary stone of: 147; cleaning of: 10; destruction of: 14; finances of: 24 . 30. 88; fines paid to: 10 ; inviolability of: 30.88 ; protection of: 88; revenues of: 10 ; see also grove

sexuality: 23.45

slaves, sacred: 14.72 (?)

soul: 8. 12. 21. 44.48

statue, cult: 14. 17. 28. 80; dedication of: 28. 39. 126

supplication, suppliant: 34.131

syncretism: 55.62

tent: 88

theft, of sacred money: 88

Theokritos: 45

theoxenia: 42

thunder: 48

thymiaterion: 52

tree: 14 ; see also grove

violence, religious: 14

virgin: 7. 108. 140

vow 2-3.28. 38. 48. 52. 150

war: $58-59.88$

water: 46

wedding: 108

women: 14. 17. 51. 61. 132; association of: 77; and athletic competitions: 69. 140; and magic: 45 ; see also virgin

\section{Greek Words}

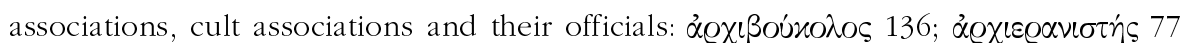

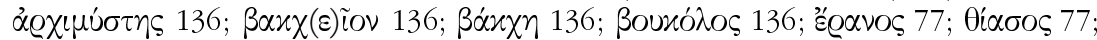

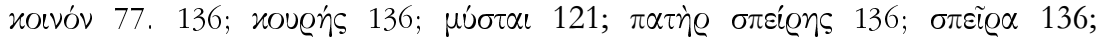

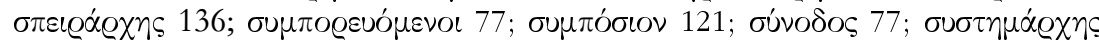

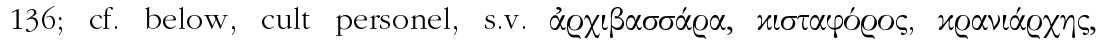

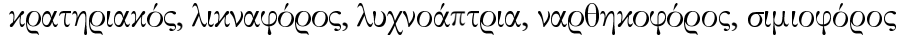

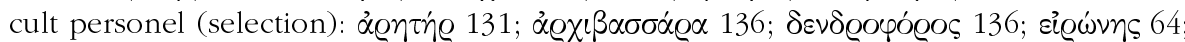

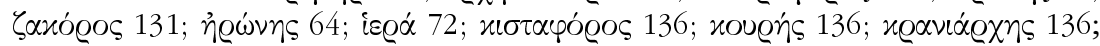

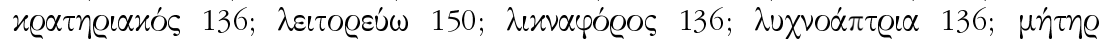

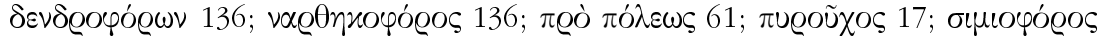

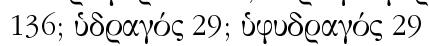

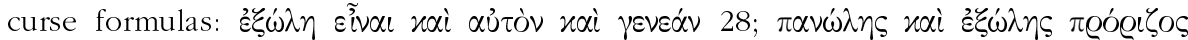

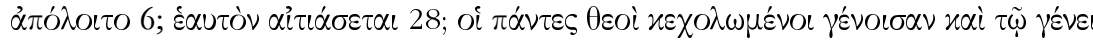

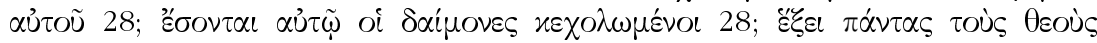




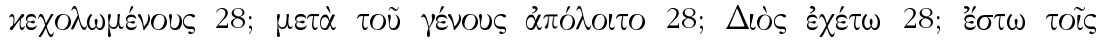

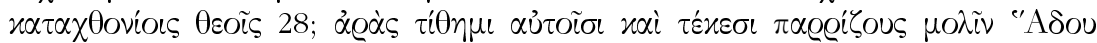

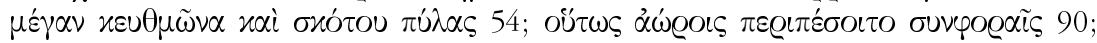

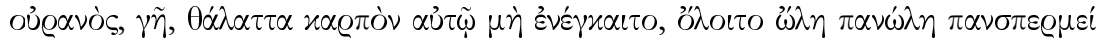

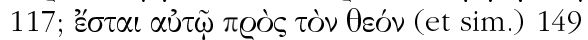

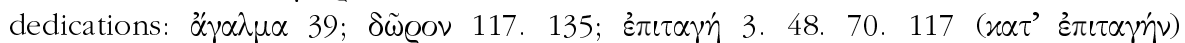

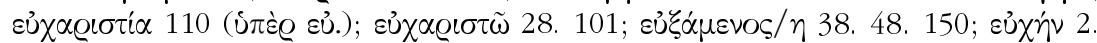

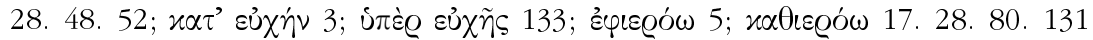

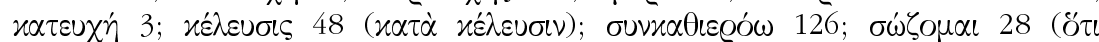

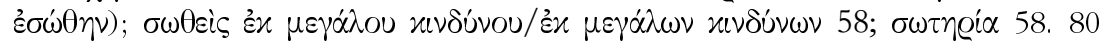

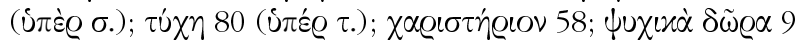

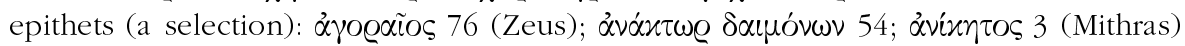

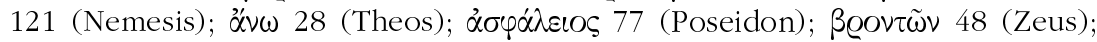

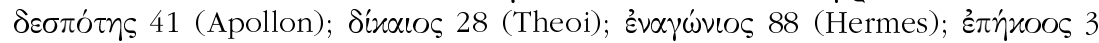

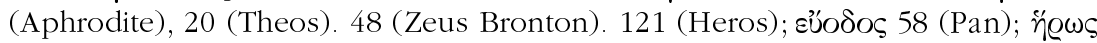

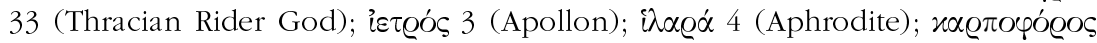

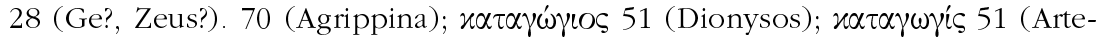

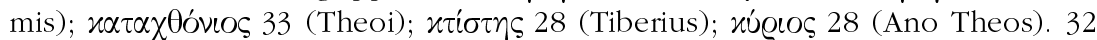
(Thracian Rider God). 121 (Poseidon); $\mu \varepsilon ́ \gamma \alpha \varsigma$ 28. 49. 55 (Theoi), 28 (Zeus);

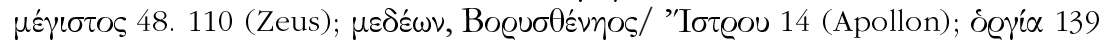

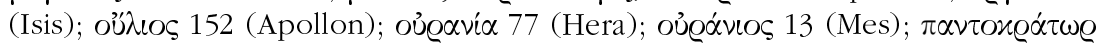

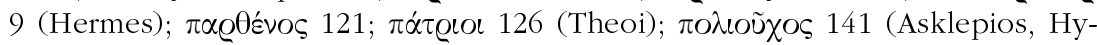

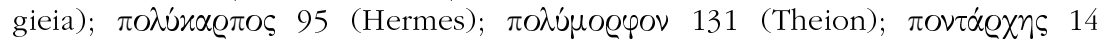

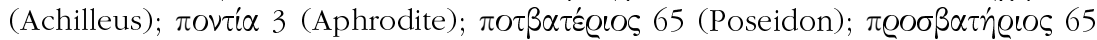

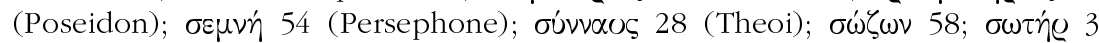
(Dioskouroi), 28 (Tiberius, Zeus). 77. 118 (Zeus). 141 (Asklepios, Hygieia);

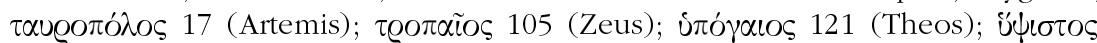

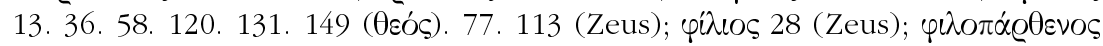

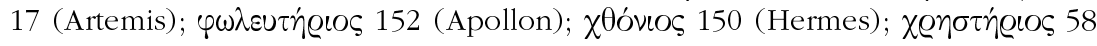
(Apollon)

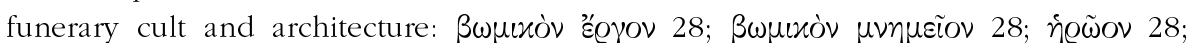

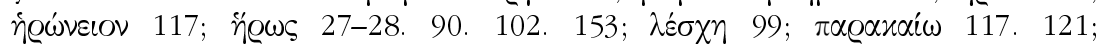

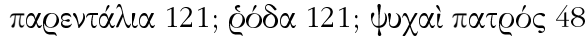

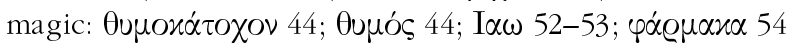

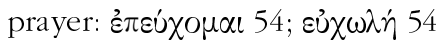

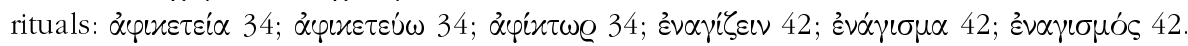

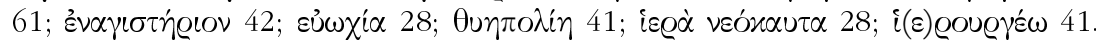

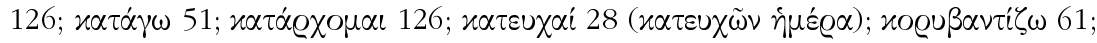

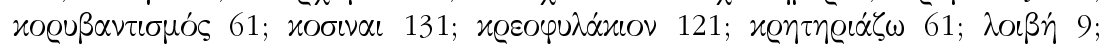

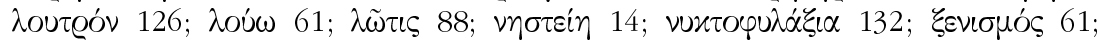

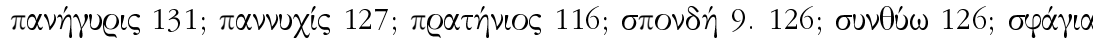
28; $\tau \varepsilon \lambda \hat{\varepsilon} \omega 61$

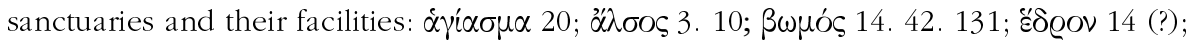

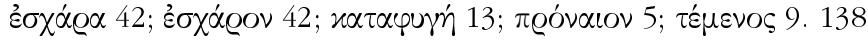

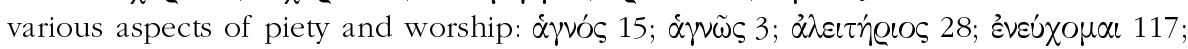

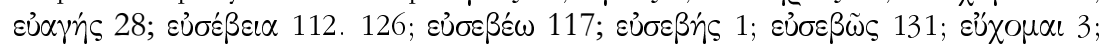

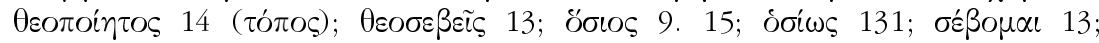

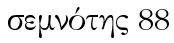




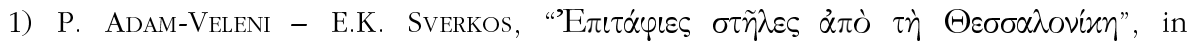

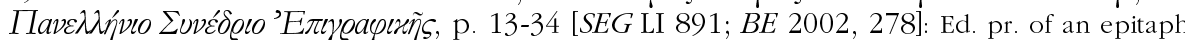

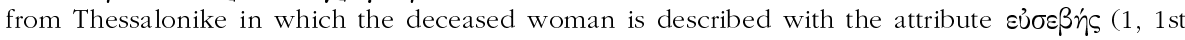
cent. B.C./A.D.). [AC]

2) N.E. AKYÜREK SAHIN, "Neue Votivbüsten für Zeus Antigo(u)naos", Olba 6 (2002), p. 71-84: Ed. pr. of four busts of a bearded man (probably a god) found in 1974 near the village Çukurören (Lydia, 3rd cent. A.D.). Two of the busts bear dedicatory inscriptions identifying the

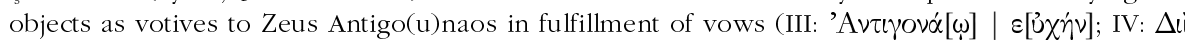

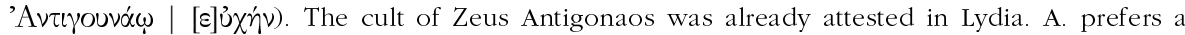
derivation of the epithet Antigonaos from the name of the cult founder (an Antigonos) [cf. EBGR 1998, 236 bis], rather than an association with a Hellenistic king [cf. EBGR 1998, 67 on p. 55]. [JM]

3) M. Alexandrescu Vianu, Histria. IX. Les statues et les reliefs en pierre, Bucarest/Paris, 2001 [SEG LI 932]: This catalogue of sculpture found in Histria includes numerous inscribed objects (bases of statues and reliefs, funerary and dedicatory reliefs, and altars). Dedications: to Aphrodite (105, by a priest after his term of office, 3rd cent.), Aphrodite Pontia Epekoos (103, 2nd cent.), Apollon Ietros and Leto (101-102, both under the priesthood of Hippolochos, 5th/4th cent.), Demeter (172, as a vow, 1st/2nd cent.), Meter Theon (104,1st/2nd cent.) [read $x \alpha \tau \varepsilon u \chi \dot{\eta}$ (vow), not $\left.x \alpha \tau^{\prime} \varepsilon^{\prime} u^{\prime} \chi \eta\right]$, the Dioskouroi Soteres (178, by the soldiers who participated in an expedition to help Apollonia, 2nd cent.), Mithras Theos Aneiketos (191 = CIMRM 2307, 2nd/3rd

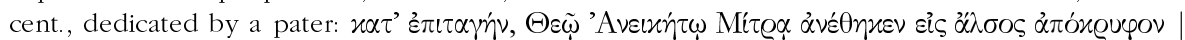

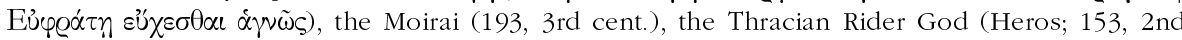

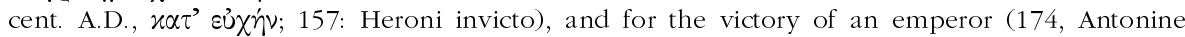
period). The statues and reliefs represent the iconography of Aphrodite, Ares, Artemis, Asklepios, Athena, Demeter and Persephone, Dionysos, Eirene, Hekate, Herakles, Kybele, the Muses, Ploutos, Jupiter Dolichenus, and the Thracian Rider God. [AC].

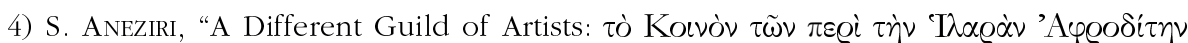

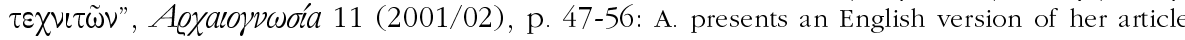
summarized in EBGR 2000, 5. A. argues convincingly that Aphrodite Hilara was the patron goddess of a guild of artists who performed in comic-erotic spectacles (phlyakes, mimes, and pantomimes) and did not participate in the official program of Greek music competitions; for this reason they had no place in the guilds of Dionysiac artists in Magna Grecia. [JM]

5) Y. Augier - M. Sartre, "Le dieu de Rabbos, maître du «temple périptère » de Canatha", MDAI(D) 13 (2002), p. 125-130: Ed. pr. of an architraval dedicatory inscription found during the excavations at the so-called "peripteral temple" of Kanatha (Syria, c. A.D. 150200) [cf. the preliminary report in $E G B R$ 2001, 131; BE 2002, 466; SEG L 1535; the excavators suggest a different date; see supra $\mathrm{n}^{\circ}$ 43]. Philippos, a member of the council, his wife, and his son financed the construction of the pronaos and dedicated it to Theos Rabbou ( $\tau$ ò $\pi$ @óvxlov |

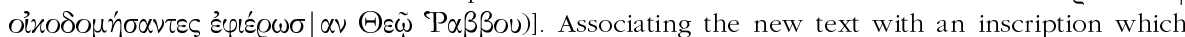
documents the dedication of a propylon to Theos Rabbou by Sithros (IGLS XVI.1, 143, A.D. 162 or 163), A.-S. suggest that Sithros dedicated the monumental entrance to the sanctuary of Theos Rabbou; Philippos and his family dedicated the pronaos of the temple. [JM]

6) M. Aydaș, "A Priest of the Goddess Ma at Komana”, EA 34 (2002), p. 23-27 [BE 2003 534]: Ed. pr. of the epitaph of an anonymous person [with a quotation from his testament] (Yehilova, Imperial period); this person set an undetermined number of slaves free, forbidding the exposure of their children and further burials in his tomb. The manumitter may have been a priest of $\mathrm{Ma}$ at Komana, since her sanctuary (200 km east of the finding spot of the text) is known to have owned slaves. The inscription contains a unique imprecation formula: "If one of the freedmen or their descendants is unjust or takes to himself something of those, which have been given by me, or damages or abuses (the tomb) [but see below], this person will offer as

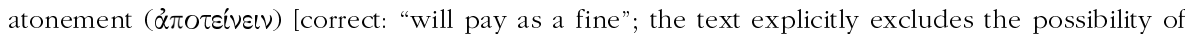
atonement] nine uncorrupt girls, nine boys, nine bulls, nine white animals with golden horns

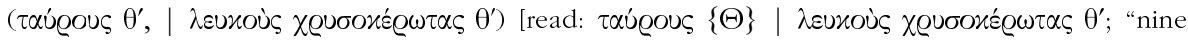


white bulls with golden horns"; there were nine types of offerings, not ten], nine cows, nine horses with golden bridles, nine white he-goats, nine she-goats, nine rams with golden fleece and nine white swallows to the goddess in Komana every year. Let this person bring these to Zeus from Thymnasa, Zeus Pharnavas, and Anaitis. (And even so) the proclaimed [aforementioned] gods will not be appeased and neither the earth will give fruit nor the sky water nor the sun light. This person will also be liable to temple-robbery and this person's root will be completely and

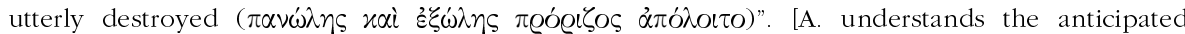
violations as being commited by the freedmen, and the beginning of the clause can indeed be

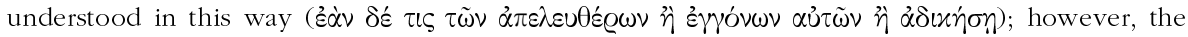
next phrase makes better sense if the freedmen are the object, not the subject of the violation: $\hat{\eta}$

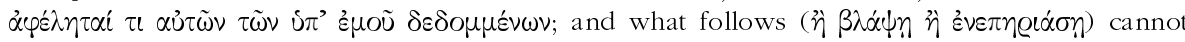
possibly refer to the tomb. As in manumission records, in general, this clause aimed at protecting the freedmen and their descendants: "and if someone violates the rights of (any of) the freedmen or their descendants of takes away from them one of the things granted to them by me, or harms them or treats them abusively/disrespectfully, etc."]. A. comments on the religious significance of the number nine. As swallows are migratory birds, the offerings were to be made during a festival in the spring. Pharnavas is a new epithet of Zeus, possibly of Persian origin (farnah = royal splendor, glory). [AC]

7) M. Bentz, "Die Preisamphoren aus dem Mosaikenhaus in Eretria", $A K 44$ (2001), p. 3-12 [SEG LI 1122]: Re-edition of three Panathenaic amphoras found in a private house in Eretria (SEG XLIII 108, 363/2 and 360/59 B.C.). The unique feature of their iconography is the representation of female personifications, which $\mathrm{B}$. tentatively interprets as Charis and the personification of the games. [Since neither Agon nor Panathenaia is female, the female personification may be that of Heorte]. This is a rare case in which the archaeological context gives information about the use of Panathenaic amphoras in private houses. In this case, these vases were probably desplayed in the peristyle in front of the banquet rooms. [AC]

8) G. Betegh, "Papyrus on the Pyre. The Derveni Papyrus and its Archaeological Context", ActaAntHung 42 (2002), p. 51-66: A survey of the significance of fire in the ideas and rituals of the 'Orphics' endorses the assumption that the Derveni papyrus was not thrown to the pyre as junk, but was designed to be burnt as part of the burial of its owner. In support of

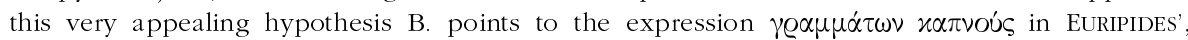
Hippolytos 953f. in the context of Orphic and Bacchic rites, to the representations of heroised persons who hold a papyrus roll in their hand, to the Orphic custom of accompanying the dead with texts, and to the special role allotted to fire in the Derveni text, in Heraclitus, and in mythological narratives. B. observes a striking convergence between the Derveni papyrus and the Orphic lamellae from Thourioi. Gold leaf C, which was found in the coffin of a cremated person, reveals despite its very fragmentary condition a connection between divinities and physical elements or parts of the cosmos (Demeter-earth, Zeus-air, Helios-fire, Moira $\pi \alpha \mu \mu \eta \dot{\sigma} \sigma \tau \omega \varrho$-the wisdom of Zeus; $c f$. the use of the verb éuń $\alpha \tau$ o in connection with Zeus' creative power in the Derveni papyrus); these connections find close parallels in the Derveni papyrus. The reference to death by lightning caused by Moira in gold leaf A1 from Thourioi may be interpreted as a form of heroization [possibly in conscious analogy to Dionysos' death]. Further [less compelling] analogies with the Derveni papyrus are detected by $B$. in the myth of Herakles' heroization and in the Thessalian cult of Asklepios. Finally, an eschatological role is attributed to fire by Heracitus (B 16, 28, 64, 66 Diels-Kranz), in close connection with divine justice. In light of this evidence, one may suspect that the cremation of the dead had an eschatological significance in Orphic rituals, representing the destruction of the body and the liberation of the soul. [AC]

9) M. BiLe, "Une inscription crétoise en l'honneur d'Hermès: IC II, XXVIII, no 2", Cretan Studies 7 (2002), p. 21-31: B. discusses an epigram (I.Cret. II,xxviii 2, 2nd cent. A.D.) found in a cave near Axos. Salvius Menas, who regularly came as a pilgrim to the cave, honors (1. 11 and

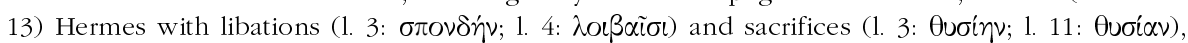

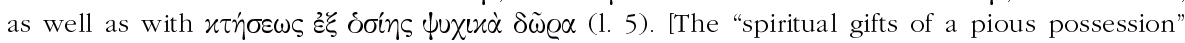
may be hymns or other poetic offerings, such as the present epigram; for the offering of "spiritual 
sacrifices" in the Imperial period see EBGR 1994/95, 41; for the assimilation of a poem to a libation see FARAONE's study summarized infra $\mathrm{n}^{\circ}$ 46]. In 1.12 Hermes is addressed as

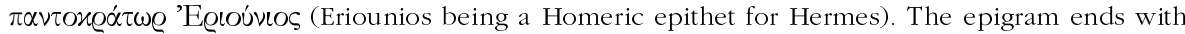

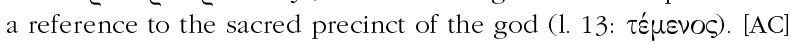

10) W. BlÜMEL, "Neue Fragmente der Pachturkunden aus Amos", EA 34 (2002), p. $107-$ 114 [BE 2003, 487]: Ed. pr. of a further fragment of the leases of land which were undertaken under the responsibility of the hieromnamones in Amos ( $3 \mathrm{rd} / 2$ nd cent.; $c f$. W. BLÜMEL, Die Inschriften der Rhodischen Peraia (ISGK, 38), Bonn, 1991, $\mathrm{n}^{\text {os }} 352-354=$ I.Rhod.Per. 49-51). The new fragment refers to fines payable to Apollon Samnaios (B 19), forbids burials in the fields which were leased (B 28-30), and mentions a sacrifice in the "fair grove" (A 17). [The latter clause provides information about the revenues of sanctuaries from groves; when one places a

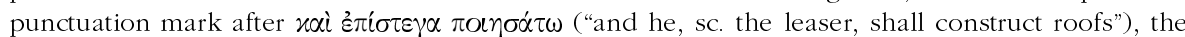
following text makes sense; it refers to the purchace of the necessary timber (not $\tilde{\omega} v$ sic O[- -], but

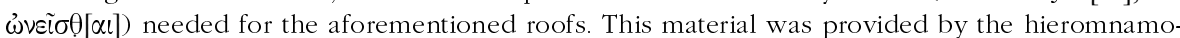
nes, who sold the branches and dry hay ( $\xi \dot{\jmath} \lambda \alpha$ and $\left.\xi_{\eta} \varrho \alpha \dot{\alpha}\right)$ collected when the grove was cleaned for the performance of a sacrifice; the $x u ́ \varrho \beta \alpha$ is not a "Weihegefäß" (as in Delos), but a unit of

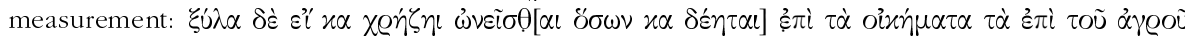

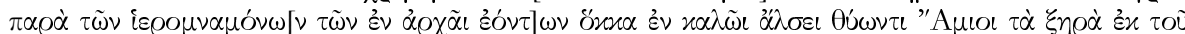

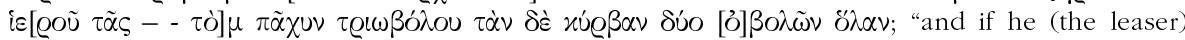
needs to purchase timber which is necessary for the (roof of the) buildings on the field, he shall buy the dry timber/hay from the sanctuary of - -, for the price of three obols a cubit and two obols a kyrba, from the hieromnamones, who are in office, when the Amians perform the

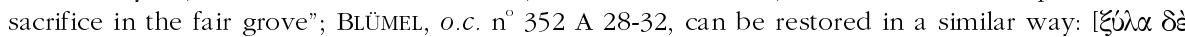

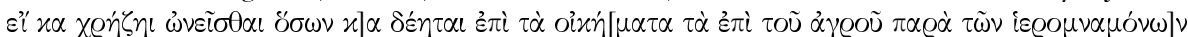

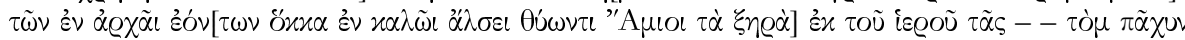

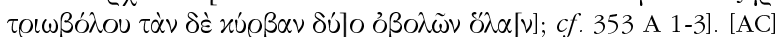

11) L. Bormann, Philippi. Stadt und Christengemeinde zur Zeit des Paulus, Leiden/New York/ Cologne, 1995: B. studies the society at Philippoi in the 1st cent. A.D., primarily in the light of Paul's letters, with occasional use of the inscriptions. We single out the discussion of the religious life, especially the emperor cult (p. 30-67, with lists of the flamines Divi Augusti et sacerdotes divae Augustae and the seviri Augustales on p. 43-46), the cult of Kybele/Magna Mater/Mater Deorum (p. 55/56), and the cult of Isis (p. 56-60). [AC]

12) G.W. Bowersock, "Notes on the New Edessene Mosaic of Prometheus", Hyperboreus 7 (2001), p. 411-415: A new mosaic from Edessa with Syriac texts (J. BALTY - F. BRIQUELChatonnet, "Nouvelles mosaiques inscrits d'Osrhoène", Mon. Piot 79 [2000], p. 31-72, c. 3rd cent. A.D.) represents the creation of mankind by Prometheus. A group of divinities, including Zeus (MRLH', "lord of the gods") and Hera (HR), observes how Hermes is bringing Psyche towards three clay statues made by Prometheus. B. identifies the three figures standing to the left of Zeus as Aion (a bearded man holding the wheel of time with the four seasons), Prometheus (a bearded

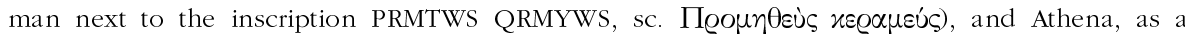
patron of potters. [AC]

13) G.W. Bowersock, "The Highest God with Particular Reference to North-Pontus", Hyperboreus 8 (2002), p. 353-362: S. Mitchell has argued that the cult of Theos Hypsistos is to be considered as a single cult, linked with Judaism ( $c f . E B G R$ 1998, 109), while Y. Ustinova (The Supreme Gods of the Bosporan Kingdom, Leiden, 1999) insisted that a single cult has never existed [cf. EBGR 2001, 175 and already 1991, 241]. B. rejects MiTchelL's views stressing that designations of divinities should be seen in their local context; e.g., in Athens Zeus Hypsistos is perceived as a divine healer, which is uncharacteristic of Zeus elsewhere and inconceivable in a Jewish context; the dedication of a divine foot in bronze to Theos Hypsistos in Termessos (TAM III.1, 32) is clearly pagan; a text at Sibidounda which mentions Theos Hypsistos in the context of

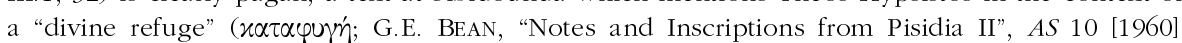
p. $70 \mathrm{n}^{\circ}$ 122) is Jewish, but in the neighbouring Andeda a dedication to Theos Hypsistos was 
made by a pagan priest of Mes Ouranios (ibid., p. $65 \mathrm{n}^{\circ} 115$ ); similarly the expression $\theta \varepsilon 0 \sigma \varepsilon \beta \varepsilon i \varsigma$ does not necessarily have the same meaning in every place. The only evidence which correlates the theosebeis with worshippers of Theos Hypsistos (CYRIL. AlEX., PG 68.281-282) refers, as B. argues, to a local group in Palestine. With regard to the associations of the worshippers of Theos

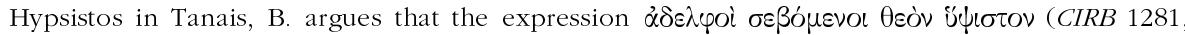
$1283,1285,1286$ ) is not compelling evidence for Jewish influence. A different local cult of Theos Hypsistos is attested at Pantikapaion (Kerch) in connection with manumission inscriptions of a Jewish or highly Judaized community (e.g. CIRB 70-71, 73, 985). In two documents the freedmen were expected to show their devotion to the Jewish synagogue; the expression $\chi \omega \underline{\text { Q is }} i \varsigma \tau[\dot{\eta}] \nu$

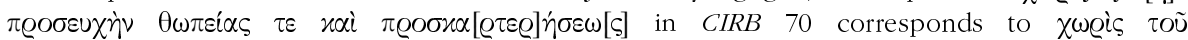

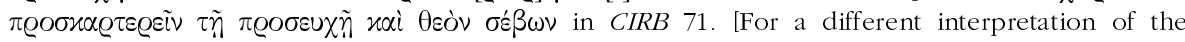
obligation of these freedmen see $E B G R$ 1996, 57, where it is pointed out that the verbs $\theta \omega \pi \varepsilon u ́ \omega$ and $\pi \varrho O \sigma \varkappa \alpha \varrho \tau \varepsilon Q \varepsilon ́ \omega$ often express the duties of servants (e.g., Demosth. LIX 120; PLATO, Theaet. 173 a; PSI V 525 1. 16); this clause is compared to the obligation of persons dedicated to divinities to serve their sanctuaries on the days of festivals (see EBGR 2000, 155); according to this interpretation, the manumitted slaves were free, except for services they had to offer to the synagogue on certain occasions]. [AC]

14) B. Bravo, "Luoghi di culto nella chora di Olbia Pontica", in Problemi della chora coloniale, p. 221-266 [SEG LI 969-970]: B. discusses many inscriptions which provide evidence for the cults and sanctuaries in the territory of Olbia, in particular for the cult of Achilleus (Achilleus Pontarches) on the promontory of Bejkuš, Apollon Ietros and Apollon Delphinios in Berezan and Olbia ( $S E G$ XXXVI 693-694; XLI 612; XLII 712; XLIV 651), and Demeter and Kore in a small sanctuary near Zajač ja balka (6th cent. B.C.); sherds with the inscriptions K and THP are interprteted as referring to $\mathrm{K}(\mathrm{K}(\dot{\mathrm{o}} \varrho \eta))$ and Demeter $\left(\left[\Delta \eta \mu \eta^{\prime}\right] \tau \eta \varrho\right)$ [but theonyms on graffiti are usually in the genitive or the dative; in which sense is a nominative used here?]. According to B., the place names Borysthenes and Istros in the epithets 'A $\pi$ ó $\lambda \lambda \omega \nu$ 'I $\eta$ qoòc

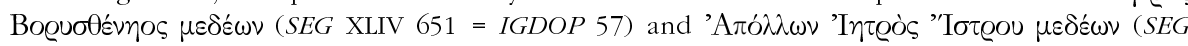
XLII $712=I G D O P$ 58) are the rivers Borysthenes and Istros (and not the respective cities). In a dedication to Apollon Ietros (IGDOP 54) the lettering is deliberately designed in such a way as to suggest a long meandering line, as an allusion to the river. In a dedication to Achilles (IGDOP 53)

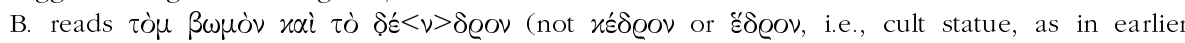
editions). A large part of the article is dedicated to a new critical edition and commentary of a private letter preserved on an ostrakon in Olbia (SEG XLII 710; IGDOP 24, c. 550-510 B.C.; p. 253264). According to his interpretation, the letter was written by an Olbian magistrate (or priest), who lived in Berezan, to another higher magistrate in Olbia. The letter refers to the excessive

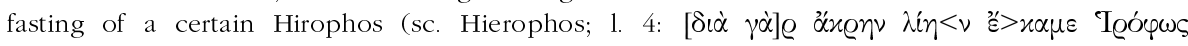
$\nu \eta \sigma[\tau \operatorname{sin\nu }])$; he may have been a priest in Berezan, whose fasting may be related to the cult of the

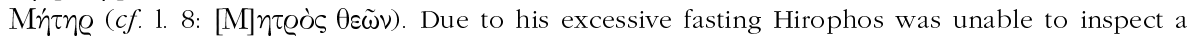

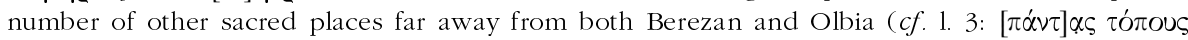

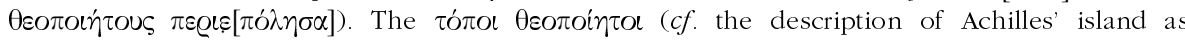
$\varkappa \tau \varepsilon \dot{\tau} \tau \iota \sigma \mu \alpha$ $\theta \varepsilon \tilde{\omega} \nu$ in $B E 1991,419)$ may be identified with Chalkeie (1. 5) and Hylaie (1. 6). B. argues

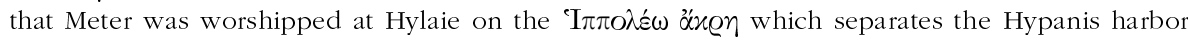
from that of Borysthenes ( $f f$. SEG XLII 709; Syll. 730 1. 13-20). The slaves, who according to the letter ran away after a shipwreck (1. 8), are likely to have served in a sanctuary in Hylaie; Metrophanes (1.9) is an appropriate name for a priest of Meter. The women in Chalkeie, who are

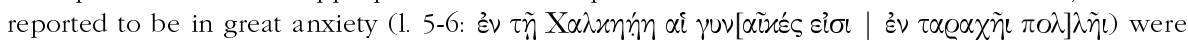
probably also priestesses. The text mentions the destruction of sanctuaries (1. 7: of $\beta \omega \mu$ oi

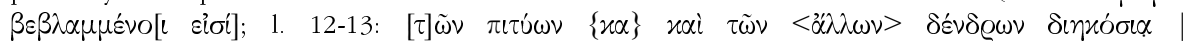

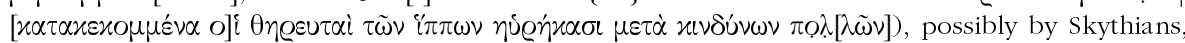

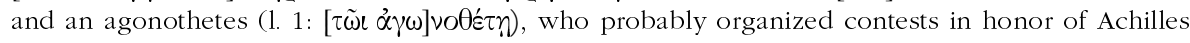
in Berezan. $[\mathrm{AC}]$

15) J.N. Bremmer, "How Old is the Ideal of Holiness (of Mind) in the Epidaurian Temple Inscription and the Hippocratic Oath?", ZPE 141 (2002), p. 106-108 [BE 2003, 317]: B. proposes a new date for the inscription which according to the literary sources (CLEM. 
AlEX., Stromateis V 1, 13, 3; PORPHYRIOS, de abstinentia II, 19, 5) stood above the portal of the temple of Asklepios in Epidauros requiring purity of mind from those who entered the temple. According to B. the inscription mentioned belongs owing to the terminology used ( $\dot{\alpha} \gamma \operatorname{coc}_{c}$ and ÖбเO૬) not to the early 4th cent. B.C. [cf. EBGR 1997, 71], but to the late 1st cent. B.C. or early 1st

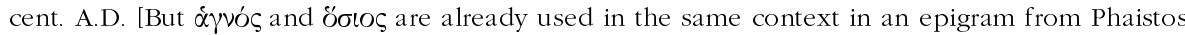

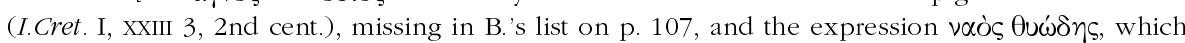
is also used in the Epidaurian text, is epigraphically attested as early as the 4th cent. B.C. (EBGR 2001, 143 = SEG LI 239); it seems more likely that the texts from Rhamnous and Phaistos have been influenced by the temple inscription of Epidauros than vice versa]. [JM]

16) S.B. Bujskin, "La dynamique d'aménagement du territoire rural d'Olbia pontique", in Problemi della chora coloniale, p. 317-332: In a discussion of the cult of Achilleus on Cape Bejkuš [cf. supra n ${ }^{\circ}$ 14] B. reports that during his excavations in 1985/1986 and 1995/1996 several inscribed sherds were found, which name Achilleus and possibly Hekate (6th cent. B.C.) [but EKA can be an abbreviated name (e.g., Hekataios]. [AC]

17) A.V. Celgin, "Termessos Tanrlari ve Kent Alanindan Artemis'in Yeni Epithet ve Kültlerini Belgeleyen Üç Yazit", Adalya 5 (2001-2002), p. 121-136: In a general study on the cult of the primary deities at Termessos, Zeus Solymeus and Artemis, C. publishes two dedications to Artemis (p. 125-127). The city dedicated a statue of Artemis Philoparthenos (early 3 rd cent. A.D.). A priests [of Artemis] dedicated a statue of Artemis Tauropolos ( $\tau \dot{o} \not \alpha \gamma \alpha \lambda \mu \alpha$

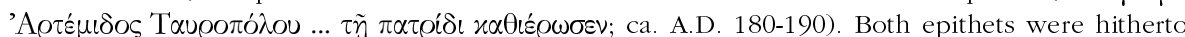

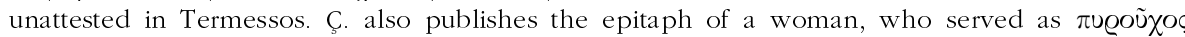

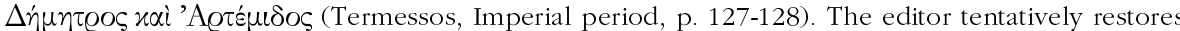

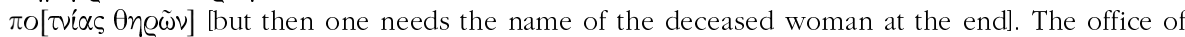
the $\pi$ ugoũ $0 \varsigma$ [the keeper of a sacred fire, probably on the altar of Demeter] is attested for the first time. The inscription provides evidence for a cultic connection of Demeter and Artemis. The fine for a violation of the grave was to be paid to Zeus Solymeus [cf. EBGR 1991, 40;1992, 103; SEG XLI 1268, 1270, 1278, 1280-1282, 1285-1286, 1289, 1300]. [AC]

18) A. Chaniotis, "Some Cretan Bastards", Cretan Studies 7 (2002), p. 51-57: C. collects the epigraphic evidence for the use of metronymics by illegitimate children on Crete. He mentions an unpublished dedicatory inscription on a bronze vessel found in the Idaean Cave ( $c f$. SEG XLIV 714, late 6th/early 5th cent. B.C.), identifying the dedicant as Phaistos, the son of

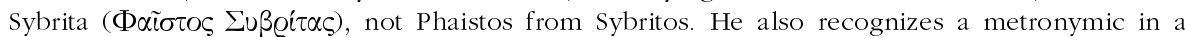

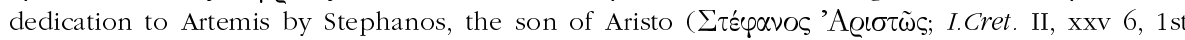
cent. A.D.). [JM]

19) A. Chaniotis, "Old Wine in a New Skin: Tradition and Innovation in the Cult Foundation of Alexander of Abonouteichos", in E. DABRowa (ed.), Tradition and Innovation in the Ancient World (Electrum 6), Krokow, 2002, p. 67-85: The success of the new cult of Glykon Neos Asklepios introduced by Alexander of Abonouteichos can be attributed to the adoption, modification, and extension of existing religious traditions and to the conscious combination of traditional and innovative elements in this cult foundation. A comparison of the information provided by LuCIAN with contemporary religious trends known from the epigraphic sources reveals a convergence, e.g., in the staging of the cult foundation ( $c f$. IG X.2, 255; LSAM 20), in the combination of oracle, healing cult, and mysteries, in the divinatory practices (e.g., TAM V.2, 1055), in the theosophical oracles given by Glykon (cf. SEG XXVII 933), in the rituals of the mystery cult, in the propagation of moral doctrines (cf. LSAM 20), and in the importance of hymnody (SEG XXXVII 961-980; LSAM 28, 69; R. MERKELBACH - J. STAUBER, "Die Orakel des Apollon von Klaros", EA 27 [1996], p. 1-54 $\mathrm{n}^{\mathrm{os}}$ 2, 4, and 11). The exploitation of traditional cultic elements made the new cult seem familiar to potential followers; at the same time, the construction of a distinctive profile enabled the worshippers to establish a close relationship to the new cult and to acquire thereby to a certain extent a new religious identity. These efforts should be seen within the context of religious competition in the second century A.D. [Cf. ID., Wie erfindet man Rituale für einen neuen Kult? Recycling von Ritualen - das 
Erfolgsrezept Alexanders von Abonouteichos (Forum Ritualdynamik, 9), Heidelberg, 2004 (www.ub.uni-heidelberg.de/archiv/5103).] [AC]

20) A. Chaniotis, "The Jews of Aphrodisias: New Evidence and Old Problems", SCI 21 (2002), p. 209-242: The famous inscription recording the names of Jews and godfearers at Aphrodisias (SEG XXXVI 970) [Cf. EBGR 1987, 95; 1992, 209; 1993/94, 165] is traditionally regarded as a single text dating to C. A.D. 200. A close study of the form of the monuments shows that the two inscribed sides bear two unrelated texts; a study of the onomastics and the letter forms suggest a date in c. 350-400 for the earlier text (on side B), and in the 5th/6th cent. for the later text (on side A). New evidence (graffiti, representations of Jewish symbols) demonstrates the strong presence of a Jewish community in late antique Aphrodisias. Equally interesting is the epigraphic evidence for a religious interpenetration [cf. infra $\mathrm{n}^{\circ}$ 149]. The dedication of Flavius Eusebios, a former soldier, to Theos Epekoos (SEG XXXVII 851), demonstrates an ambiguous use of Jewish, Christian, and pagan religious vocabulary, which makes an unequivocal attribution to a particular religious group impossible and thus renders this text an instructive example of blurred boundaries among religious groups: the name Eusebios was very popular among the Christians, but it was occasionally used by Jews as well; the dedicant uses the Jewish expression 'from the gifts of God' which, however, was adopted by Christians as well; it is difficult to assume that Eusebios was a Jew, since he was a soldier (primipilarius); the expression theos epekoos is widely attested for a variety of pagan gods, but it is never attested in Christian texts and uncertainly in Jewish ones. A similar ambiguity can be seen in the dedication of Polychronios 'to the god' (MAMA VIII 457). The dedicator's name is attested in Aphrodisias for at least two theosebeis; a Jewish or Christian context is evoked by the word hagiasma (holy place?, consecration?) which is often used both in the Septuaginta and in Christian inscriptions; Polychronios was the son-in-law of a pagan (or a Jewish?) priestess; his dedication was made for a certain Fl. Er., who may be identified with the pagan governor of Caria Fl. Quinctilius Eros Monaxius (c. 355-360). This evidence for the Aphrodisian Jews should be seen in the context of the religious interpenetrations and complexities of the 4 th and 5th cent. A.D. [cf. infra $\mathrm{n}^{\mathrm{os}} 21$ and 149]. [AC]

21) A. Chaniotis, "Zwischen Konfrontation und Interaktion: Christen, Juden und Heiden im spätantiken Aphrodisias", in C. AcKermann - K. E. Müller (eds), Patchwork: Dimensionen multikultureller Gesellschaften, Bielefeld, 2002, p. 83-128: Discussion of the evidence provided primarily by graffiti and inscriptions for the interaction and the conflict among pagans, Jews, and Christians in Aphrodisias (c. 330-500). Particular attention is given to the great influence of the Jewish community (cf. supra $\mathrm{n}^{\circ} 20$ ), to the persistence of pagan groups until the late 5th cent. (e.g., Ch. Roueche, Aphrodisias in Late Antiquity, London, 1989, $\mathrm{n}^{\mathrm{os}}$ 25, 40, 47, 56), to the use of religious symbols (menorah, labrys) and characteristic personal names by the various religious groups, in particular by the Jews, to the evidence for the crossing of religious boundaries, to the interdependence of the three groups in their religious vocabulary and ideas, and to the use of pagan motifs in Christian inscriptions (e.g., Roueche, o.c., $\mathrm{n}^{\text {os }} 38$ and 156). The religious ambiguities of this period are particularly clear in a small group of funerary epigrams for pagans, which stress the idea of the immortality of the soul (ROUECHE, O.c., $\mathrm{n}^{\text {os }} 33,54,153 \mathrm{~b}, 154$, 157; SEG XLVIII 1327; Anth. Gr. VII 690). [AC]

22) A. Chaniotis, "Foreign Soldiers - Native Girls? Constructing and Crossing Boundaries in Hellenistic Cities with Foreign Garrisons", in A. CHANIOTIS - P. DuCREY (eds), Army and Power in the Ancient World, Stuttgart 2002, p. 99-113: This survey of the relations between garrisons and native populations in Hellenistic cities includes a discussion of the religious aspects primarily in the light of the epigraphic sources: the contribution of garrison soldiers to the ruler cult, e.g., in Itanos (I.Cret. III, iv 4), Thera (IG XII.3, 464, 1390, and 1391), and Cyprus (OGIS 20), dedications of soldiers in sanctuaries in the cities where they served, cult transfer through garrison soldiers, e.g., with regard to the Egyptian deities (IG XII.3, 443, 463 , 1389; I.Cret. III iv 14; SEG XXXI 1521), and the activities of cult associations of soldiers (e.g., SEG VIII 714). [On these subjects see now A. CHANIOTIS, War in the Hellenistic World: A Social and Cultural History, Oxford 2005, p. 149-154]. [AC] 
23) A.S. Chankowski, "O'̣́єıv. Remarques sur les inscriptions rupestres de Théra et sur

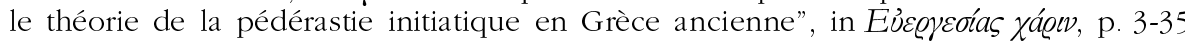
[BE 2003, 414]: The Archaic rock-cut inscriptions of Thera (IG XII.3, 536-540, 8th-6th cent.) which use the verb olipw to describe homoerotic copulation have traditionally been interpreted as evidence for initiatory pederasty, similar to that described by EPHOROS (FgrHist $70 \mathrm{~F} 149=$ StRABON X 4, 2) for Crete. A study of the significance of the verb o"í $(c f$. I.Cret. IV 72 col. II 2) and of the noun oi $\varphi \dot{\lambda} \lambda \eta \xi$, which is used in obscene contexts (IG XII.5, 97; BE 1958, 377; SEG XV 517; IGDOP 27), makes the assumption that the homoerotic inscriptions of Thera belong to a ritualized context highly improbable. [AC]

24) V. Chankowski, "De l'argent jeté dans les fontaines ? La "Minoé" de Délos et les jarres du trésor sacré à la fin de l'indépendance", in Eủeoyeoías xáotv, p. $37-49$ [BE 2003, 397]: The Delian

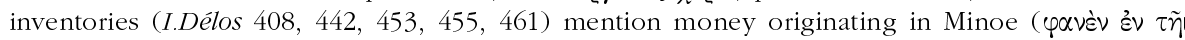

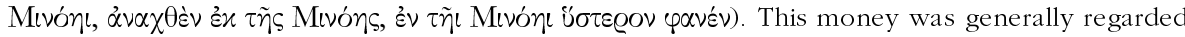
as money thrown by pilgrims in the fountain Minoe in Delos. CH. rejects this interpretation and argues that it is money given as a loan to Minoa in Amorgos [but see the critical remarks of Ph. GAUTHIER, BE 2002, 397]. [AC]

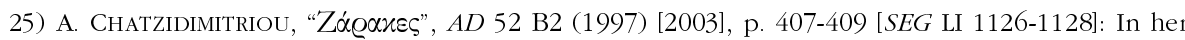
report on the excavation of buildings near Zarakes Karystou (ancient Zarex, Euboia) C. mentions several inscriptions of the type iモoó (abbreviated as i๕.), which suggest a cultic function for the buildings (7th-4th cent). A fragment of a relief pithos with the representation of a Centaur found in a building of the late Geometric period (building II, possibly a shrine) bears a graffito [we read on the photo the letters isgòs Z...[- -]]. A bronze weight with representation of a ram's head in

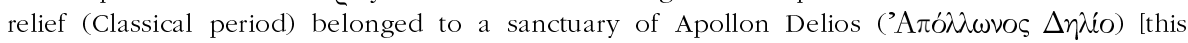
sanctuary?]. [AC]

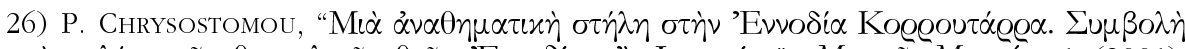

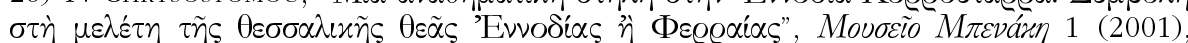
p. 11-20 [English summary; SEG LI 739]: C. publishes a dedication to Ennodia Korroutara

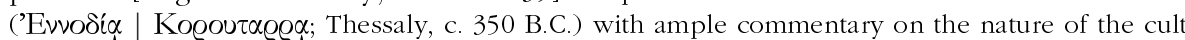
of Ennodia [cf. EBGR 1998, 57]. The epithet of the goddess was hitherto unattested. C. interprets it

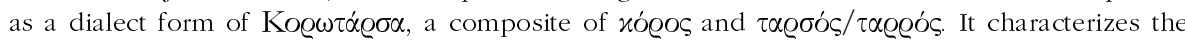

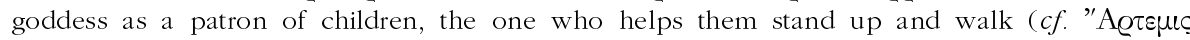

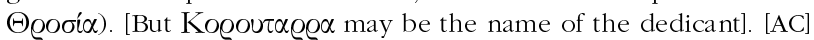

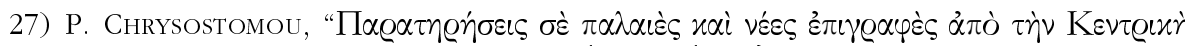

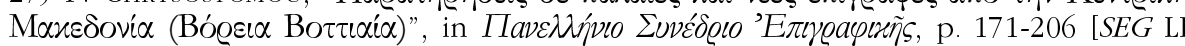
840 and 852; $B E$ 2002, 269]: Ed. pr. of two epitaphs from Pella in which the deceased persons are designated as ท̆ $\varrho \omega \in c ̧$ (2 and 14, Pella, 2nd/1st cent.). [AC]

28) T. Consten, Die Inschriften von Kibyra. Teil I. Die Inschriften der Stadt und ibrer näheren Umgebung (IGSK, 60), Bonn, 2002: The first of three volumes dedicated to the inscriptions, history, and topography of Kibyra presents the inscriptions found in the city and its vicinity (the southwest part of the valley of Alassos). New texts are marked with an asterisk. Dedications: The most interesting dedications are two thanksgiving dedications to Asklepios (82:

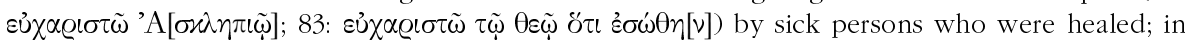

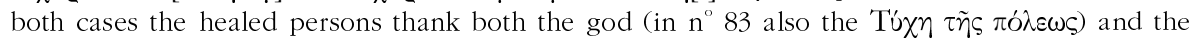

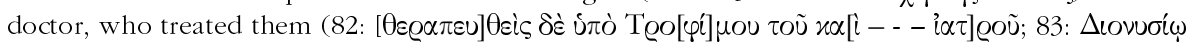

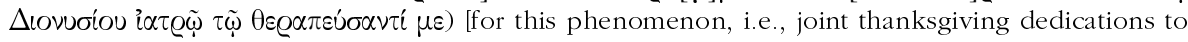
Asklepios, for the divine assistance, and the physician, for the treatment, see the comments in EBGR 1999, 148 on $\mathrm{n}^{\circ} 118$ and infra $\mathrm{n}^{\circ}$ 58]. The disease is mentioned in one of the texts ("suffering in the genitals", $\pi \alpha \theta \dot{\omega} \nu$ $\alpha i \delta o i o v)$. We single out a group of dedications to gods, who are

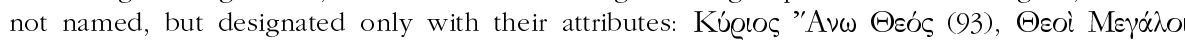

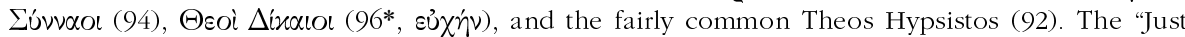
Gods", who may be associated with Theoi Hosioi in I.Prusa 25 and 28 and Theoi Hosioi kai Dikaioi in I.Prusa 26, 95-96, are hitherto unattested local gods; they are represented on a rock-cut 
relief as three male and one female divinities. A large group of dedications in fulfillment of vows ( $\varepsilon \cup \chi^{\prime} \nu$ ) are addressed to the Dioskouroi. These rock-cut inscriptions are engraved under relief representations of the Dioskouroi in four cult places, at Kizilbel (87), Anbarcik (88*), Kücük Kilckaya (89-90), and Bayir (91*). The remaining dedications are addressed to Apollon Chereu-

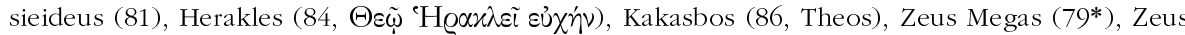
Philios, Homonoia, and Thea Rhome (2, the treaty between Plarasa/Aphrodisias, Kibyra, and

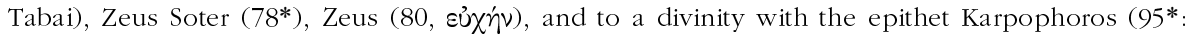
$[\Delta l] i$ or $[\Gamma] \tilde{\eta})$. There are also two fragmentary dedications to unknown divinities represented in rock-cut reliefs as a rider god $\left(99^{*}\right)$ and as three male gods $\left(100^{*}\right.$, one of them with a doubleaxe) respectively. Cults: The cult of Thea Rhome is attested through the treaty between Rome and Kibyra, which mentions the base of a gold statue of Roma (1, 2nd cent.). Emperor cult: A priest of

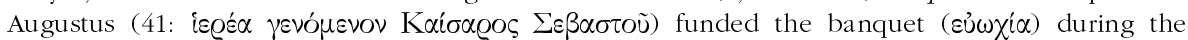

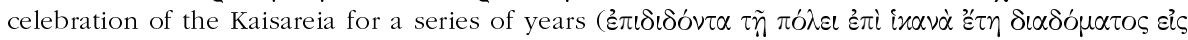
$\varepsilon \cup \omega \chi i \alpha \nu \mathrm{K} \alpha \iota \sigma \alpha \varrho \varepsilon i \omega \nu)$. The first day of the month was called $\Sigma \varepsilon \beta \alpha \sigma \tau \dot{\eta}$, in honor of Augustus (291). High priests of the emperor cult are often mentioned in honorific inscriptions and epitaphs: high priests of the emperor cult in Asia (12) and in the city (63), a couple of a high priest and a priestess of Asia (62; cf. 232), a high priestess of the city emperor cult (69), and several Asiarchs (63, 69-71, 149) and Lykiarchs (63, 69). The emperor cult is indirectly attested through dedications to Tiberius, called soter and ktistes (3; note the verb $x \alpha \theta \imath \varepsilon \varrho o ́ \omega)$, Britannicus (4-5), Antonia Augusta (6), and Septimius Severus (?, 13*). Cult officials: Priests of Apollon (60), Arete (41-42),

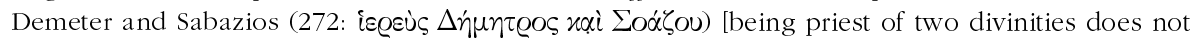
necessarily imply that these divinities had a joint cult or sanctuary as synnaoi, as C. suggests (p. 243)], Zeus Soter (44), and an unknown divinity $(348,352)$. Two priests held their priesthoods

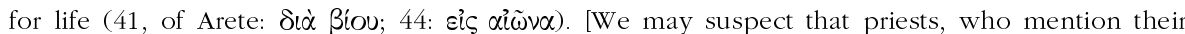

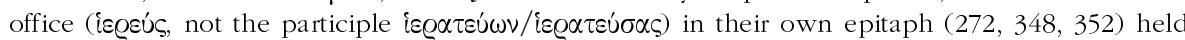
these offices for life, and did not die during an annual term]. The other cult personnel includes a neokoros (319).

Rituals: The treaty between Plarasa and Aphrodisias, Kibyra, and Tabai (2), describes the oath ceremony ("they also made an oath in the presence of newly burned sacrificial animals and a

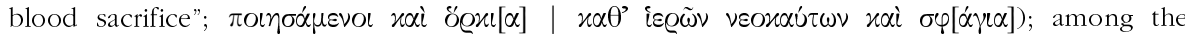

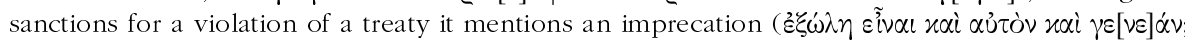
"he and his descendants should perish"). A document, which provides for measures for the protection of the gymnasiarchical funds donated by Q. Veranius Troilos Philagros (43, 1st cent. A.D.) contains an imprecation formula against any violator: "they and their descendants should be accursed and sinners with regard to the emperors, the senate, the fatherland, and the sanctuaries

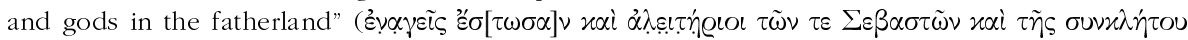

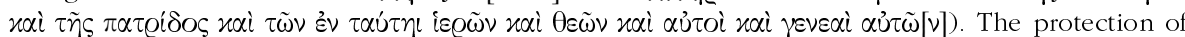
these funds was also included in the traditional oath taken annually by the ephebes in the

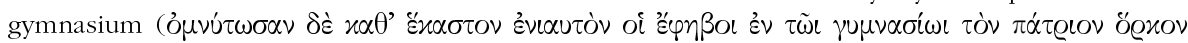

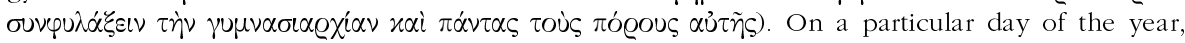

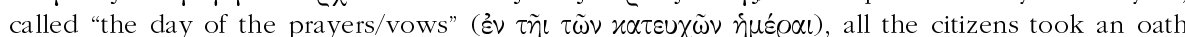
under the supervision of the magistrates and the secretary of the assembly to protect these funds. [The "day of the vows" may have been a day at the beginning of the year, possibly the day on

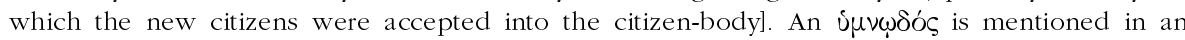
epitaph; the naming practices of his family (Men-ophantos, Menis) suggest that he did his service (in singing hymns in a chorus) in the cult of Mes (276) [on the importance of hymnody in the Imperial period see supra $\mathrm{n}^{\circ} 19$. With regard to the rituals of honoring benefactors, we note the

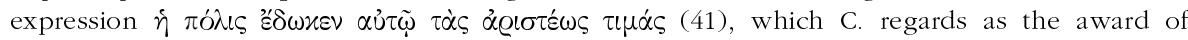

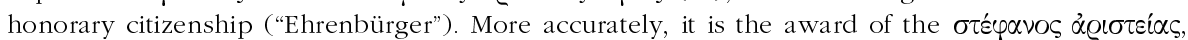
i.e., a particular type of crown usually given for bravery, but also for other services; see the examples in A. CHANIOTIS, "Griechische Rituale der Statusänderung und ihre Dynamik", in M. STEINICKE - S. WEINFURTER (eds), Investitur- und Krönungsrituale, Cologne/Weimar, 2005, p. 56]. The verb $x \alpha \theta$ เєó́w (37) alludes to the rituals performed during the dedication of statues (in this case the statue of the governor Q. Aemilius Lepidus). [ $\mathrm{N}^{\circ} 379^{*}$, a text written on a rock 
fragment, is included among the epitaphs, but this is questionable. The last lines (3-4) can be

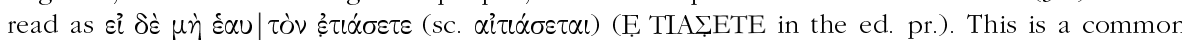
imprecation that follows an interdiction: "otherwise he will accuse himself", i.e., he will be subject to a curse; e.g. Th. ReINACH, "Inscriptions d'Aphrodisias", REG 19 (1906), p. 103-105 nº 17: 'Éa

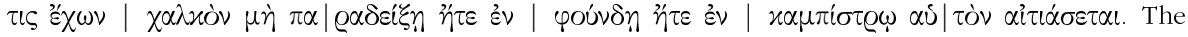

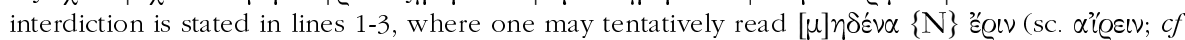

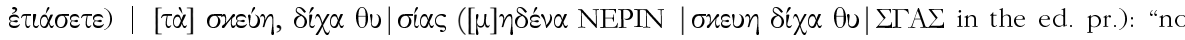
one should remove the receptacles, except for a sacrifice". According to this interpretation, this is a rock-cut inscription in a cult place, where a person donated receptacles or other implements for the performance of a sacrifice $(c f . E B G R$ 1992,154) and wanted to make sure that they would not be removed]. Divination: An alphabetical oracle has already been presented in EBGR 1997, 90.

Grave cult and afterlife: In only two cases are the deceased persons called heroes (288*:

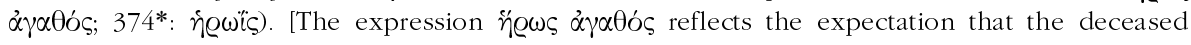
person would offer protection to the living; $c f$. F. GRAF, Nordionische Kulte, Rome, 1985, p. 130

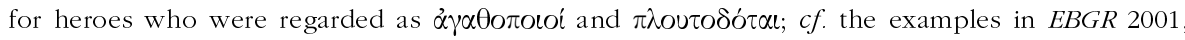
120 (comment on $S G O$ II 09/06/18)]. Among the terms used to describe funerary monuments and their parts we select but a few: $\beta \omega \mu$ ó $(136,153,164,200,218-219,227,261,271,282,284,347$,

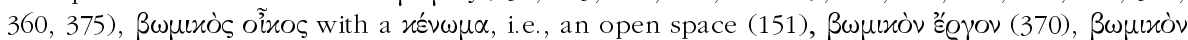

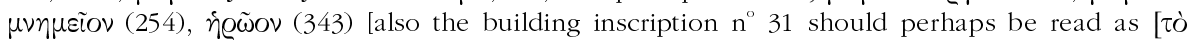

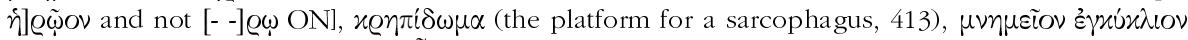

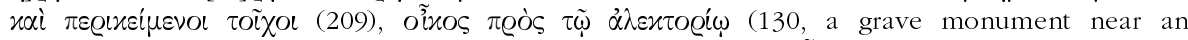

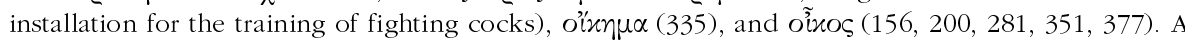
grave monument was divided between the families of two persons, who probably used the

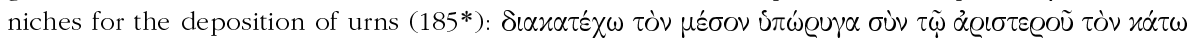

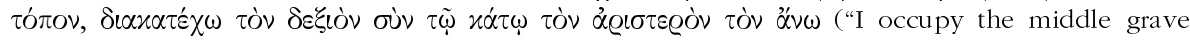
chamber and the lower part of the left one; I occupy the right grave chamber and the upper part

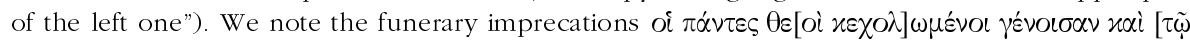

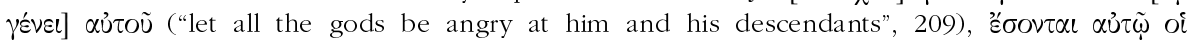

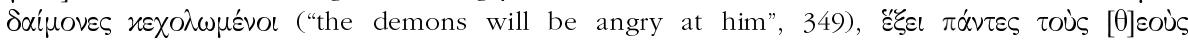

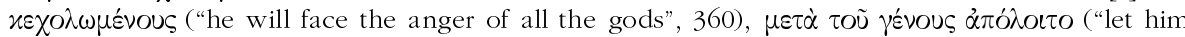
perish, together with his descendants", 308), $\Delta$ เò $̇$ é $\chi^{\prime} \tau \omega$ ("let him face the wrath/punishent? of

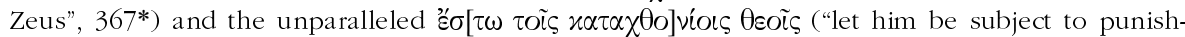
ment by the gods of the underworld", 194*). Two epitaphs close with apophthegms concerning

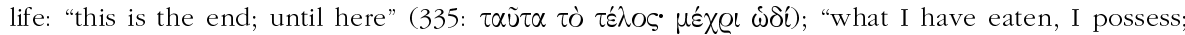
what I have left behind, I have lost; Philistion was telling the truth, when he said this; the life is

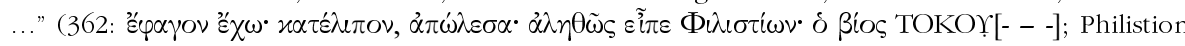
was a famous poet of mimes from Asia Minor in the Augustan period). [AC]

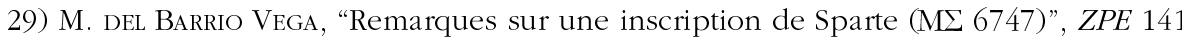
(2002), p. 134-136: B. discusses briefly an inscription (late 3rd cent. B.C.) found in secondary

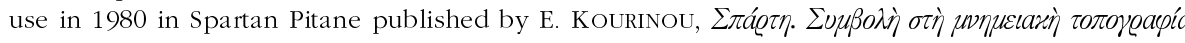
$\tau \eta$, Athens, 2000, p. 225. The inscription refers to the dedication of statues of a hydragos, and two hyphydragoi to the Dioskouroi by the enigmatic association of the Aihiatai (= Aisiatai). While KOURINOU left the question of the exact character of the Aisiatai open, B. attempts to reconstruct a cult association in honour of Poseidon Aisios, whose cult is known on Delos (I.Délos 1562, 1574, 1581, 1582, 1902; 102/101 B.C.); the worship of Poseidon and the Dioskouroi in Pitane is attested by Pausanias. [But Poseidon was worshipped as Hippokourios in Pitane, and his cult was separate from that of the Dioskouroi; does the worship of Poseidon Aisios on Delos (late 1st cent. B.C.) suffice for postulating a cult association in honor of Poseidon Aisios in Sparta in the 3rd cent. B.C.?]. [JM]

30) B. Dignas, Economy of the Sacred in Hellenistic and Roman Asia Minor, Oxford, 2002: Based on epigraphic material and literary sources D. studies the financial affairs of sanctuaries in Asia Minor, particularly at Aizanoi, Baitokake, Ephesos, and Labraunda. Despite the vastness and the complexity of the material $\mathrm{D}$. attempts a systematic approach to this subject 
using inventory lists, euergetic claims, financial disputes, royal decisions, annual expenditures, complaints by different authorities, and appeals by priestly instances. The author argues for the existence of some kind of independence of the sanctuaries from the city administrative organs, the Hellenistic kings, and the Roman emperors. We cannot present here a detailed review of this significant contribution to the study of sanctuaries in Asia Minor. Among the different subjects treated by $\mathrm{D}$. we single out the corruption and mismanagement of temple revenues (e.g., the edict of Paullus Fabius Persicus concerning the revenues of Artemis Ephesia; I.Ephesos 18b, A.D. $44)$, the sale of priesthoods, and the role of festivals as financial factors. In two appendices D.

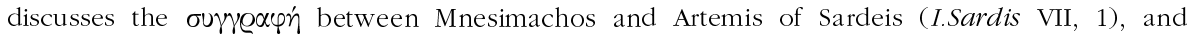
aspects of the inviolability of sanctuaries in Asia Minor. [JM]

31) B. Dignas, “Inventories' or 'Offering Lists'? Assessing the Wealth of Apollo Didymaeus”, ZPE 138 (2002), p. 235-244: After an overview of the temple records from the Athenian Akropolis D. briefly discusses similar epigraphic evidence from the sanctuaries of Apollon Didymeus near Miletos (I.Didyma 424-478), Hera on Samos (D. OHLY, "Die Göttin und ihre Basis. Appendix 7: Schatzinschrift", MDAI[A] 68 [1953], p. 46-50) [see now IG XII.6, 261], and Athena in Lindos (I.Lindos 2). The author concludes that there are important differences between the Athenian and the Delian 'inventories', with their obvious emphasis on the aspect of the delivery of the dedications [cf. EBGR 1992, 130-131], and the East Greek 'offering lists' which seem for some reasons to be incomplete and unsystematic (Didymaion), exceptional (Samos), or fictional, bringing together mythical and real donors (Rhodos). [JM]

32) B. Dignas, "Priestly Authority in the Cult of the Corybantes at Erythrae", EA 34 (2002), p. 29-40 [BE 2003, 444]: D. presents a new critical edition of the lex sacra concerning the sale of the priesthood of the Korybantes at Erythrai $(\mathrm{A}=$ I.Erythrai 206; B $=$ SEG XLVII 1628)

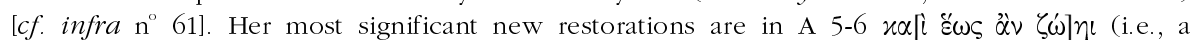

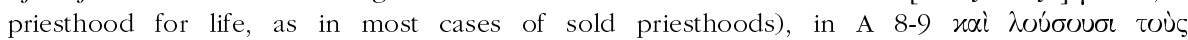

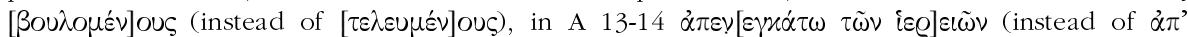

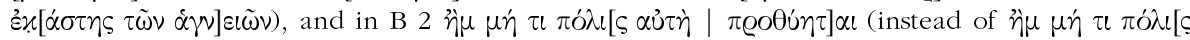

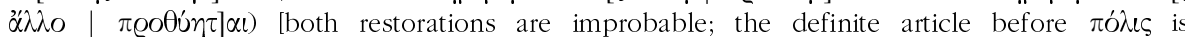
indispensable; the text cannot possibly refer to "a" city, but only to "the" city of Erythrai; the

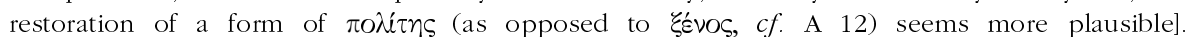
N. Himmelmann had explained this document as an effort of the city to control the hitherto private worship of the Kyrbantes. D. rightly rejects this interpretation and regards the two fragments as parts of the same diagraphe and argues that the opposition between private and public cult is inappropriate. [This is in part the result of the lack of a definition of what "public" cult means. As S. ALESHIRE has made clear (EBGR 1994/95, 6) the primarily criterium for a distinction between private and public cult is the question of who finances the rites and sacrifices; the Erythraian text clearly makes a distinction between public and private: $\tau \dot{\alpha} \delta \eta \mu \delta$ oı $\alpha$ (B 4 and 8) refers to "sacrificial animals bought with money of the demos" and is opposed to all other sacrifices, made by individuals at their own expenses]. In a more general discussion of sales of priesthoods, she stresses the importance of financial issues in leges sacrae and priesthoods,

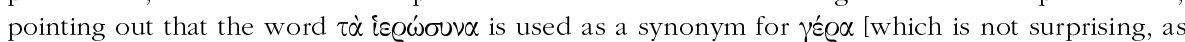

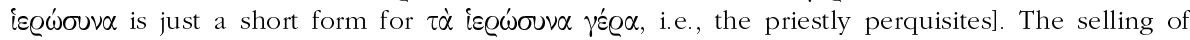
priesthoods, often for life, on the one hand increased the expertise and the authority of the buyers in matters of ritual, but also confirmed priestly rights. With regard to the terminology of the sales of priesthoods in Erythrai, D. interprets छ̇ $\pi$ purchase of the priesthood of another shrine or temple of the same deity and $\dot{\varepsilon} \pi \dot{\omega} v$ เov as a sales tax on the acquisition of priesthoods. [AC]

33) N. Dimitrova, "Inscriptions and Iconography in the Monuments of the Thracian Rider", Hesperia 71 (2002), p. 209-229 [BE 2003, 128]: The numerous Thracian rider monuments resist a pure iconographic analysis. In most cases the accompanying inscriptions provide the only evidence to determine the type of monument - votive or funerary - or the honored deity. The more than 2,000 published examples date from Hellenistic to Roman times, but the vast majority date to the Imperial period. The exact identity of the depicted horseman 
(represented facing a woman, an altar, and a snake entwined tree, hunting or returning from the hunt carrying a deer) remains unknown. The inscriptions below the relief reveal the name of the dedicant and the honored deity or the name of the deceased, sometimes accompanied by Dis

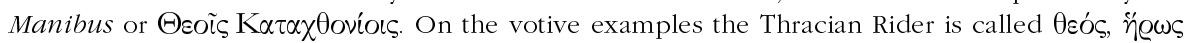

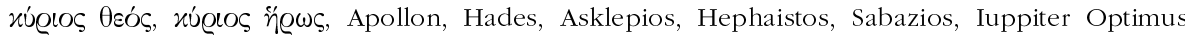
Maximus, or Silvanus, or is regarded as one of the Dioskouroi. In addition to these a variety of local names and cult epithets appears too: Karabasmos, Keilade(i)nos, Manimazos, Vetespios (Outaspios), Aularchenos, Aulosadenos, and Pyrmeroulas. According to D. the iconography of the Thracian Rider stems from a Greek artistic tradition. Yet, the accompanying inscriptions reveal that this Greek tradition was imbued with indigenous beliefs and new religious meanings. D. shows that the Thracian Rider was just an artistic convention for a god or hero and not a multifunctional, syncretistic divinity. [JM]

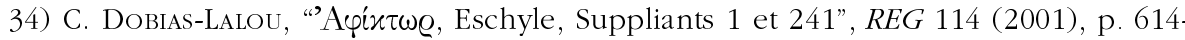
625 [SEG LI 1022, 1060, 2210]: The author plausibly argues that the word ácix AEsCHYLus' Suppliants 1 and 241 is neither an epithet of Zeus ('protector of suppliants'; Suppl. 1:

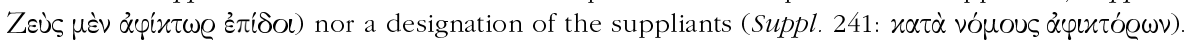
In both cases it designates the god or gods who take part into the reintegration of the suppliant.

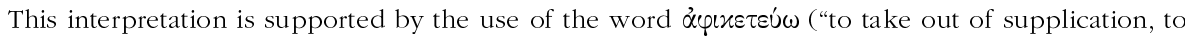
settle back into a community") in the cathartic law of Kyrene (SEG IX $72=$ LSCG Suppl. 115 1. 132-

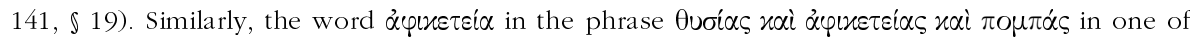
the Koan decrees concerning the foundation of the Knidian festival in honor of Artemis Hyakinthotrophos (Iscr.Cos ED 77; I.Knidos 220 1. 6, c. 200 B.C.) does not mean 'supplication', but designates the reintegration of the suppliants after successful supplication, which lead to the epiphany of Artemis. In a Lindian decree concerning suppliants (SEG XXXIX 729, 3rd cent.) [cf.

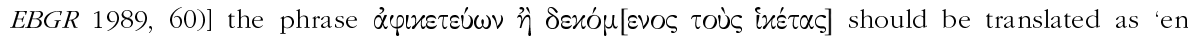
intégrant ou en accueillant les suppliants'. [AC]

35) C. Dobias-Lalou, "Une épigramme de Cyrène pour deux athlètes", Quaderni di Archeologia della Libya 16 (2002), p. 145-149: Ed. pr. of two epigrams in honor of two athletes, winners of equestrian contests (Kyrene, 2nd/1st cent.). With their references to Hermes (A), Herakles (A, B), and the Muses (B), the epigrams allude to the activities of the gymnasium.

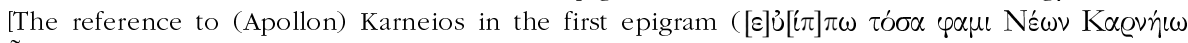
$\tilde{\alpha} \delta$ o [- - ]) may be an allusion to a victory in an agon in honor of Apollon Karneios]. [AC]

36) O. Doonan - D. Smart, "Gerna Dere, Roman and Byzantine Settlement in Sinop Province, Turkey", Talanta 32/33 (2000/2001) [2002], p. 17-26: Ed. pr. of an altar for Theos Hypsistos found in an ancient settlement at Gerna Dere (west of Sinope, 2nd cent. AD). $[\mathrm{AC}]$.

\section{7) vacat}

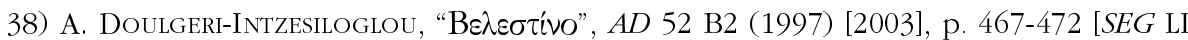
734]: Ed. pr. of a Hellenistic dedication made by a woman to Enodia in fulfillment of a vow

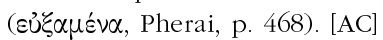

39) Th. Drew-Bear - G. Labarre, "Les trios statues de la Concorde à Antioche de Pisidie", EA 34 (2002), p. 71-92 [BE 2003, 193, 517]: Three inscriptions record the dedication of statues of Homonoia in Antiocheia in Pisidia which commemorated the concord between

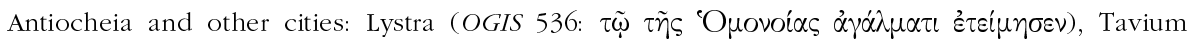

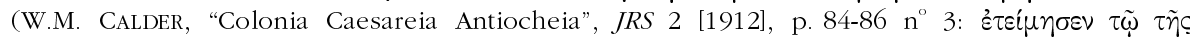

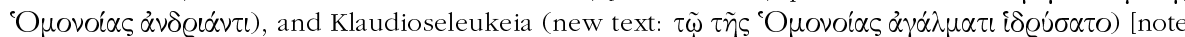
the use of the word $\dot{\alpha}^{2} \nu \delta \varrho \dot{\alpha} \zeta$ as a synonym of $\left.\dot{\alpha}^{\prime} \gamma \alpha \lambda \mu \alpha\right]$. D.-B.-L. comment on the possible historical context and on the cult of Homonoia. [AC]

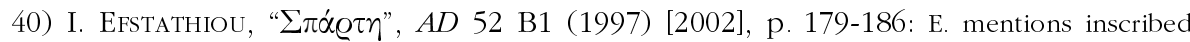

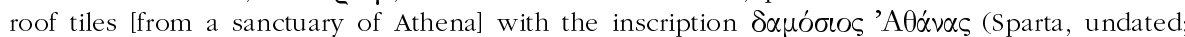
p. 186). [AC] 
41) N. EhrHARDT - W. GÜNTHER, "Funde aus Milet XV. Neue Orakelinschriften", $A A$ (2002.1), p. 47-57: Ed. pr. of four oracular inscriptions from Miletos. The first text is written on an altar. It is the inquiry of Eutyches concerning the erection of an altar for the Muses and the

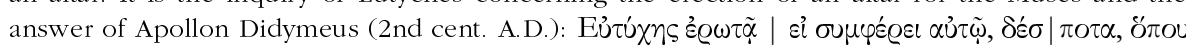

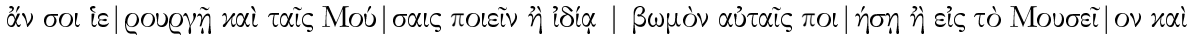

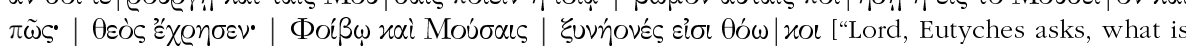
beneficial to him: to erect (an altar) for the Muses at the same place where he performs the sacred actions for you, or to erect an altar for them privately (or separately), or in the Mouseion, and in which way? The God gave the following oracle: The places for Phoibos and the Muses are common". Eutyches may have had a cult office in the service of Apollon; two of the options for the altar of the Muses (sanctuary of Apollon, sanctuary of the Muses) are public sanctuaries; consequently, isí $\alpha$ seems to refer to a private cult place, not to a separate cult place (p. 50: "völlig separate"), which already existed (the Mouseion)]. In 1. 7-8 we have the first direct epigraphical evidence for the existence of a Mouseion. The other three texts $(2-4,3$ rd cent. A.D.) are small fragments of oracular questions and responses, inscribed in groups and not individually. $\mathrm{N}^{\circ} 2$

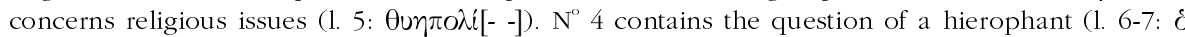

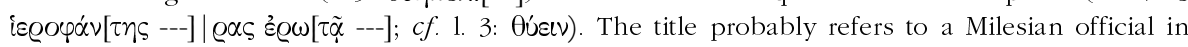
the service of the imperial cult in Miletos, and not to the Eleusinian hierophantes. [For the association of the emperor with mystery cults see H.W. PLEKET, "An Aspect of the Emperor Cult: Imperial Mysteries", HThR 58 (1965), p. 331-347; A. CHANIOTIS, "Der Kaiserkult im Osten des Römischen Reiches im Kontext der zeitgenössischen Ritualpraxis", in H. CANCIK - K. HITZL (eds), Die Praxis der Herrscherverehrung in Rom und seinen Provinzen, Akten der Tagung in Blaubeuren vom 4. bis zum 6. April 2002, Tübingen, 2003, p. 19]. [JM]

42) G. Еквотн, The Sacrificial Rituals of Greek Hero-Cults in the Archaic to the early Hellenistic Periods (Kernos Suppl. 12), Liège, 2002: Making ample use of literary and epigraphical sources, and to lesser degree of the archaeological material, E. studies the sacrificial rituals in honor of Greek heroes from the Archaic to the early Hellenistic periods [cf. EBGR 2000, 54]. In an appendix the author presents the Greek text of the sacrificial calendars of Thorikos, Marathon, and Erchia [cf. infra ${ }^{\circ}$ 83], and of the genos of the Salaminioi. In the first chapter of

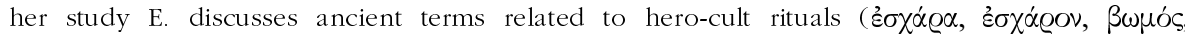

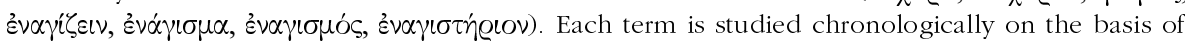
both epigraphic material and literary sources. The second chapter is dedicated to four rituals: destruction rituals, blood sacrifices, theoxenia, and thysiai followed by dining. In the third chapter E. tries to disprove the assumption that hero-cults originate in the cult of the dead. In her final chapter E. concludes that heroes were ritually assimilated to gods and had the same role in society. [JM]

43) Chr. ERTEl - K.S. Freyberger, "Zwischen Hellenisierung und Romanisierung: Ein Friesblock mit Weihinschrift aus dem Vorgängerbau des 'Peripteraltempels' in Kanatha”, $\operatorname{MDAI}(D) 13$ (2002), p. 131-169: Based on an iconographic and stylistic analysis of the lion heads framing the architraval dedicatory inscription found in the sanctuary of Theos Rabbou at Kanatha (Syria) [cf. supra ${ }^{\circ}$ 5)] E.-F. date the document in the last decades of the 1st cent. B.C. [JM]

44) Chr. A. Faraone, "Thumos as Masculine Ideal and Social Pathology in Ancient Greek Magical Spells", in S. Braund - G.W. Most (eds), Ancient Anger: Perspectives from Homer to Galen (YCS 32), Cambridge, 2003, p. 144-162: The charms labeled

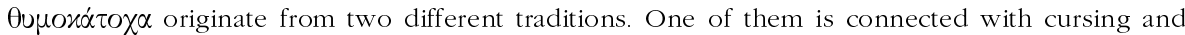
the binding of the Aujós, which originally had positive connotations (soul, spirit, will, courage; $c f$.

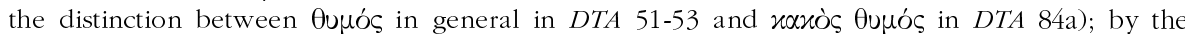

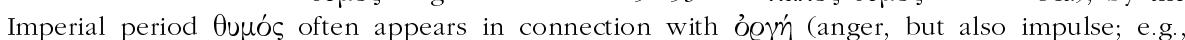
Audollent, DefixTab 22, 33; Suppl. Mag. 57, 34-44; PMG XII 179-182). The second tradition is connected with spells and amulets which aimed at warding off the anger and hostility of others ( $c f . P M G$ IX); this amuletic tradition was regularly deployed by social subordinates against their superiors; it was based on the belief that males had an excessive amount of Aupós and ỏerń, 
which were to be controlled or healed by women or social subordinates. For these reasons the

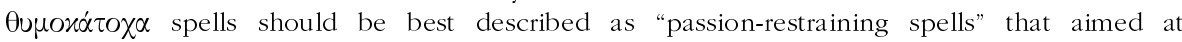
controlling a variety of phenomena, such as anger, competitive zeal, heated verbal exchanges, and erotic attraction. [AC]

45) Chr. A. Faraone, "Agents and Victims: Constructions of Gender and Desire in Ancient Greek Magic", in M. Nussbaum - J. Sinvola (eds), The Sleep of Reason. Erotic Experience and Sexual Ethics in Ancient Greece and Rome, Chicago/London, 2002, p. 400-427: F. explores the evidence provided by ancient erotic spells for the social construction of masculinity and sexual desire. Love spells fall into two very distinct categories: rituals used mainly by men to instill erotic passion in women and rituals used mainly by women to maintain or increase affection in men. Interestingly, autonomous women (esp. courtesans and prostitutes) occasionally used male spells for producing erotic passion, thus appearing as anomalous 'males'; Simaitha's spells in THEOCRITUS, Idyll II, esp. 23-32, belong to this group. Ancient love spells occasionally show an inversion of the natural gender, aiming at transforming the "naturally" chaste and moderate female to a passionate lover and the "naturally" lascivious male to a calm and subordinate person. In this context F. comments on a series of amulets (R. KOTANSKY, Greek Magical Amulets: The Inscribed Gold, Silver, Copper, and Bronze Lamellae. Part I. Published Texts of Known Provenance, Opladen, 1994, $\mathrm{n}^{\text {os }}$ 40, 58, and 60) and magical papyri (PGM XIII 250; XVII a; XXXVI 35-68). [AC]

46) Chr. A. Faraone, "A Drink from the Daughters of Mnemosyne: Poetry, Eschatology, and Memory at the End of Pindar's Isthmian 6", in J.F. Miller - C. DAMON - K.S. MYers (eds), Vertis in usum. Studies in Honor of Edward Courtney, Leipzig, 2002, p. 259-270: PINDAR's Isthmian 6 1. 66-75 ("I shall offer him a drink of Dirke's sacred water, which the deepbosomed daughters of golden-robed Mnemosyne made to surge by the well-walled gates of Kadmos") alludes to eschatological ideas and in particular to the water of Memory mentioned in the 'Orphic' lamellae; this allusion expresses the idea that the praise poetry of Pindar can provide a special kind of happiness that can persist even in the underworld. [AC]

47) G. Ferrari, "The Ancient Temple on the Acropolis at Athens", AJA 106 (2002), p. 11-35: Based on archaeological material, inscriptions, and literary sources $\mathrm{F}$. argues that the Archaic temple of Athena on the Acropolis of Athens was neither destroyed completely during the Persian sack of the city nor taken down at a later date, but that it remained standing and partially functioning until the Roman period. [JM]

48) P. FreI, "Inschriften und Reliefs. Ein Beitrag zur lokalen Religionsgeschichte Anatoliens", in Zona Archeologica, p. 135-158: F. studies the iconography of a group of altars dedicated to Zeus Bronton (1-9) and Zeus Pyrgenos (10, attested for the first time) from Inönü and its vicinity (territory of Dorylaion); these monuments seem to be related to the same sanctuary (2nd-3rd cent.); $\mathrm{n}^{\circ \mathrm{s}} 7-10$ are published for the first time ( $3=S E G$ XXXII $1275 ; 4=S E G$ LIV 1042; cf. EBGR 1994/95, 304; 6 = SEG XL 1236). The common feature of these altars is their decoration with the bust of a bearded deity (Zeus Bronton) on the front; additional decorative elements are found on the other sides, such as further busts $(1,6,9)$, a sacrificial scene (1), animals (eagle: $2-4,6,8,10$; ox: 1), cult objects and symbols (baetyl: 4-5; gorgoneion: 9; thunder: 4; boukrania: 1-4, 6, 8, 10), vases (1, 3, 5-6), agricultural implements (plough: 1, 3-4, 6; sickle: 3, 6; pickaxe: 3,6$)$, crowns $(1,2,4-6,10)$, and rosettes $(1-2,5,10)$. The inscriptions usually begin with the invocation $\dot{\alpha} \gamma \alpha \theta \tilde{\eta} \tau \dot{x} \times \eta$ (1, 2, 4-5, 7-10), followed by the name of the divinity, dedicatory formulas, and the names of the dedicants. Zeus Bronton (1-9) is addressed with the epithet

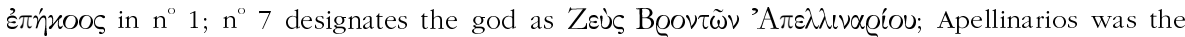
founder of a cult of Zeus Bronton [nor necessarily a private cult, as F. (p. 152) suggests; for

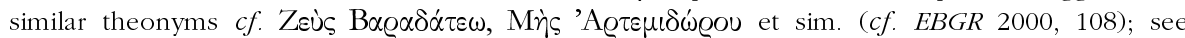
F. GSCHNITZER, "Eine persische Kultstiftung und die 'Sippengötter' Vorderasiens", in W. MEID H. TRENKWALDER (eds), Im Bannkreis des Alten Orients. Studien zur Sprach- und Kulturgeschichte des Alten Orients... Karl Oberbuber zum 70. Geburtstag gewidmet, Innsbruck, 1986, p. 45-54]. An inscription on the back of an altar dedicated to Zeus Bronton specifies that the altar belonged to 


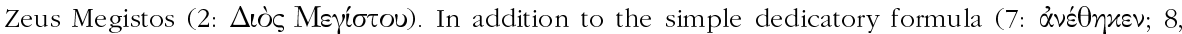
10: $\alpha \dot{v} \varepsilon \tau \tau \eta \sigma \varepsilon v / \alpha \nu$ ), more complex formulas explain that the dedications were made in fulfillment

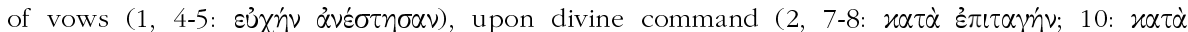

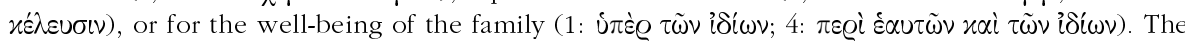
reason for the vow is explicitly stated in one case (5: safe return from journeys to Dacia and

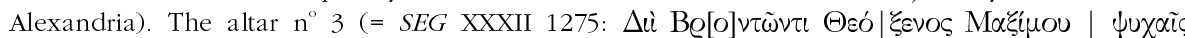

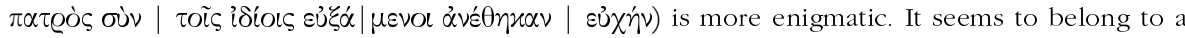
group of funerary monuments dedicated to divinities (cf. C.W.M. COX - A. CAMERON, MAMA V, Manchester 1937, p. XXXIV-XXXVIII), but its formulation is unusual ("Theoxenos, son of Maximos, together with the members of his family dedicated this vow to Zeus Bronton for the souls ["für die Totengeister"] of his father in fulfillment of their vow"). [According to F.'s interpretation, this is a funerary altar ("Grabstein") placed under the protection of Zeus Bronton.

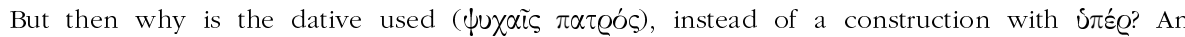
alternative reading and interpretation may be suggested. If one places a full stop after $\Delta u$ $\mathrm{BQ}[0] \nu \tau \tilde{\omega} \nu \tau \iota$, the altar is a dedication both to Zeus Bronton, protector of the living and patron of agricultural activities ( $c f$. the representation of agricultural implements, such as pickaxe, sickle, and plough), and to the protective spirit of the heroised Maximos: "To Zeus Bronton. Theoxenos, son of Maximos, together with the members of his family dedicated this vow to the souls of his father in fulfillment of their vow." This interpretation may be also supported by the form of the monument (altar) and its iconography (table with jug, cup, and krater, wine amphora), which allude to the performance of rituals, possibly a heroic cult of Maximos]. [AC]

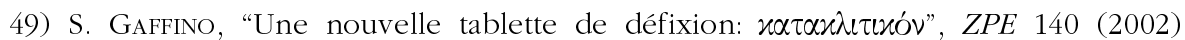
p. 185-194 [BE 2003, 146]: Ed. pr. of a defixio of unknown provenance now in a private collection (3rd-4th cent.). The first lines (1. 1-21) contain voces magicae which seem to correspond to those in Suppl.Mag. 42 11. 27-34 (Hermopolis, 3rd-4th cent.). In the last lines (1. 22-31) the defigens, whose name remains unknown, devotes Nonnos, the son of Sopatra, to the Great Gods, also invoking the stele of Plouton and (or among) the chthonic gods. The reason for the cursing of Nonnos is not specified. The victim should remain in his bed struck by fever. He should not be

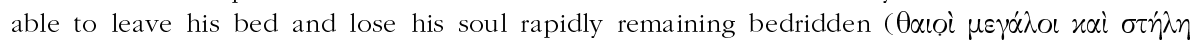

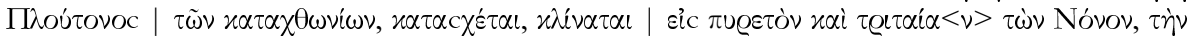

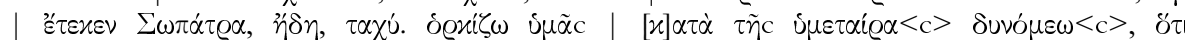

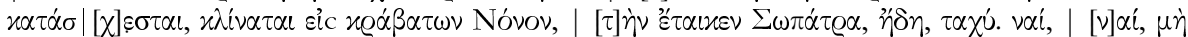

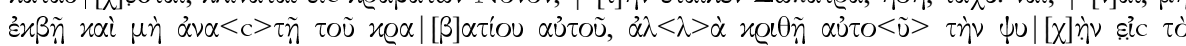

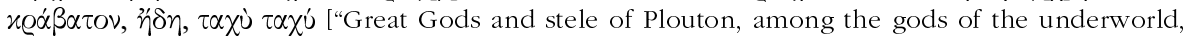
take possession of Nonon, whom Sopatra bore, turn him (his condition) to fever and three-dayfever, already now, fast; I adjure you on the name of your power, that you may take possession of Nonons, whom Sopatra bore, and make him bedridden, already now, fast; indeed, indeed, so that he will not be able to leave his bed and stand up from his bed, but his soul will be judged/condemned to the bed (sc. he will be condemned to die bedridden), already now, fast, fast"]. [JM]

50) P.-L. Gatier, "Bulletin épigraphique", REG 113 (2000), 571, n 681 [SEG XLIX 2103]: G. restores the abbreviated name of the deity to which a soldier made a dedication in Philadelphia (Khirbat Yajuz, Jordan, Imperial period; $c f$. EBGR 2000, 192) as Zeus Olympios. [AC]

51) L. GenTiLe, "L'epiteto $x \alpha \tau \alpha \gamma \omega \gamma$ íc e l'uso del verbo $x \alpha \tau \dot{\alpha} \gamma \omega$ in ambito religioso", RFIC 127 (1999), p. 334-343 [SEG XXXIX 2357; BE 2002, 538]: The epithet Katagogis, attested for Artemis in Kyrene ( $S E G$ IX 13; $c f$. SEG IX $72 \S \mathrm{VIII}$ ), has been interpreted by P. PERLMAN as the "Clothed" [EBGR 1990, 241]. Although the verb $x \alpha \tau \dot{\alpha} \gamma \omega \omega$ and its derivatives - Dionysos Katagogios in Priene (LSAM 37) and the festival Katagogia in Eryx, Priene, Miletos, Ephesos, and Athens (LSAM 37 and 48; LSCG 49; ATHEN. IX 934 f; H. Usener, Acta S. Timothei, Bonn 1877, p. 11) - are frequently used in connection with the return of a divinity (usually Dionysos) to a sanctuary or a place [see also W. BURKERT, "Katagógia-Anagógia and the Goddess of Knossos", in R. HÄGG N. MARINATOS - G. NORDQUIST (eds), Early Greek Cult Practice. Proceedings of the Fifth International Symposium at the Swedish Institute at Athens, 26-29 June, 1986, Stockholm, 1988, p. 81-87], 
the periodic return to a sanctuary is not a feature of Artemis' cult. G. prefers to associate the epithet katagogis in Kyrene with $\varkappa \alpha \tau \dot{\alpha} \gamma \omega$ in the meaning "to lead to a lower place" and with rituals during which female worshippers descended to the Nymphaion. [AC]

52) Gorny \& Mosch, Giessener Münzhandlung, Auktion 119. Kunstobjekte der Antike. Mittwoch, 16. Oktober 2002, Munich, 2002: The catalogue of an auction in Munich includes several inscribed objects. A marble statuette of a Nike was dedicated by Papias to Hekate (p. 16

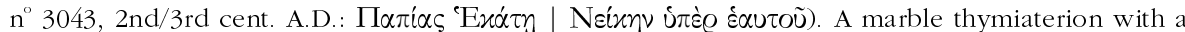

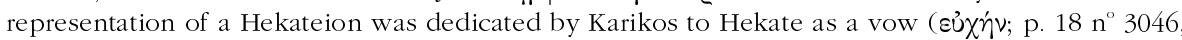
$2 n d / 3$ rd cent. A.D.). A jasper gem bears a representation of Abrasax with I $\alpha \dot{\omega}$ and a magical logos (EHQXIEYSEHIEEHTH ; p. $42 \mathrm{n}^{\circ} 3134,2 \mathrm{nd} / 34 \mathrm{~d}$ cent. A.D.). A carneol gem has the representation of the dead Osiris and an anthropomorphic falcon, surrounded by the inscription $\Psi \mathrm{N}$ P $\Sigma \mathrm{T} \Lambda$ (p. $56 \mathrm{n}^{\circ} 3270,2 \mathrm{nd} / 3 \mathrm{rd}$ cent. A.D.). A dedicatory plaque in the form of an aedicula, in which Apollon Klarios is seated, is inscribed with the monogram ПА (p. $110 \mathrm{n}^{\circ} 3558$, late Imperial period) [cf. infra $\mathrm{n}^{\circ}$ 53]. [AC]

53) Gorny und Mosch, Giessener Münzhandlung, Auktion 111. Kunstobjekte der Antike, Dienstag, 16. Oktober 2001, Munich, 2001 [SEG LI 2249-2250, 2273]: This auction catalogue contains two magical gems of unknown provenance (p. 68): a gem of green jasper with representation of Abrasax and the inscription I $\alpha \omega$. $(3241,2 \mathrm{nd} / 3 \mathrm{rd}$ cent.) and a hematite gem with the representation of an enthroned Zeus holding the eagle in a temple and two goddesses with cornucopia, corn-ears and a bird on the akroteria of the temple (obverse) and voces magicae on the reverse ( $\Lambda \mathrm{ME} \Lambda \Lambda|\mathrm{OMMIM}| \mathrm{E} \Lambda \Omega \Phi \mathrm{I} \Sigma|\mathrm{I} \Sigma \mathrm{PO} \Omega \Sigma \mathrm{I} \Sigma| \mathrm{I} \Phi \mathrm{PNO} \mid \mathrm{XXEO} \varsigma \Omega ; 3243$, 3rd cent. A.D.). A bronze plaque has the form of an aedicula, with a seated Apollon of the type of the cult statue of Apollon Klarios in the aedicula; the monogram $\Pi$ A is on ist back (unknown provenance, Imperial period, $103 \mathrm{n}^{\circ}$ 3444). [AC]

54) F. GRAF, "Fluch und Segen. Ein Grabepigramm und seine Welt", in Zona Archeologica, p. 183-191: G. describes the religious context of a very interesting grave inscription from Alexandria ( $G V 1875$, c. 2 nd/1st cent.). In the first part of this metrical text Thermin, a woman who died in young years as a result of a disease, implores the divinities of the underworld to

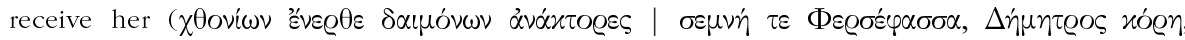

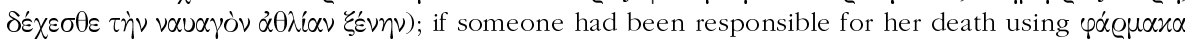
(magic or poison), she invokes the divinities of the underworld to punish this person with the

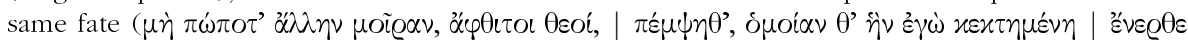

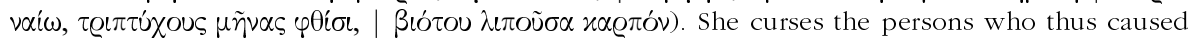

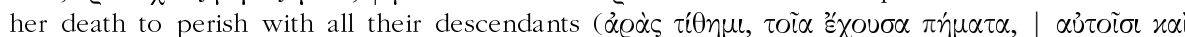

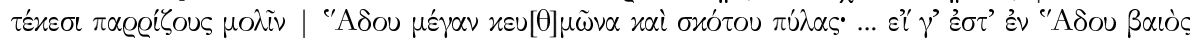

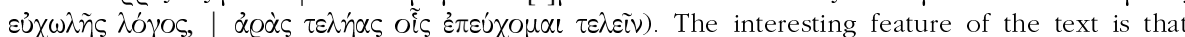
Thermin combines this curse with a blessing for her children and her husband ( $\tau \dot{\varepsilon} x \nu \omega \nu \delta^{\prime} \varepsilon \dot{\varepsilon} \mu \tilde{\omega} v$

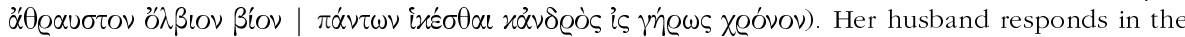
second part of the epigram, promising her to take care of her children. G. associates this text with other ancient evidence for the suspicion that a premature death was the result of poison or magic and for the cursing of the unknown culprits; lacking legal possibilities for the punishment of these (known or unknown) persons, the relatives of their victims cursed them. To the mainly epigraphical evidence collected by G. BJörck (Der Fluch des Christen Sabinus, Upsala, 1938), G. adds further examples (IG XII 8, 540; SEG VII 1239; OGIS 697; AUdOLLENT, DefixTab 1; G.S. BEAN, The Inscriptions of Side, Ankara, 1965, n 12; cf. CIL VI 12649, 19747, 20906; Carmina Latina Epigraphica 1534 B) [see also EBGR 2000, 127]. G. urges not to make a distinction between

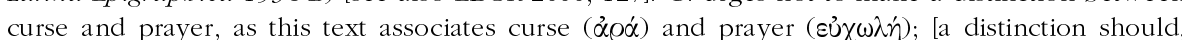
nevertheless, be made between curses, in which a justification is given ("prayers for justice") and those defixiones which lack this feature; G. suggests the term "Vergeltungsgebete" (prayers for revenge)]. [AC]

55) A.J. Graham, "The Colonization of Samothrace", Hesperia 71 (2002), p. 231-260 [BE 2003, 420]: Based primarily on archaeological material but using also literary sources and 
inscriptions from the Samothrakian cemeteries and the sanctuary of the Great Gods, G. argues that the Greek colonists came to the island from Samos. Numerous graffiti on pottery sherds from the sanctuary and the cemeteries in Greek script but in a non-Greek language are interpreted by G. as evidence for the use of a non-Greek lingua sacra by the Greek inhabitants of Samothrake in the cult of the Great Gods between the Archaic and the Hellenistic period. A non-Greek cult already existed in Samothrake, when the first Greek colonists arrived from Samos in the 6th cent. The adoption of cult and language by the colonists presupposes at least a short period of coexistence of Greek and non-Greek elements. In a useful appendix G. presents a catalogue of the inscriptions on pottery from Samothrace 2.2 that have been republished in the pottery catalogues of later volumes in the series of the Samothrake publications. [JM]

56) B. Grimes, "IG II $^{2}$ 1198: Money Awarded by Attic Demes for the Purpose of Sacrifice", $Z P E 140$ (2002), p. 80 [BE 2003, 255]: According to a new restoration of an Athenian honorary inscription ( $I G \mathrm{II}^{2} 1198$ 1. 10-11, 4th cent. B.C.), funds for a sacrifice (ten drachmai) and a golden crown (with a value of 100 drachmai?) were given to the honorand directly from the demos treasury. Only three more Attic demotic decrees of the 4th cent. B.C. attest to the same combination of honors. In these cases the amount given for the sacrifices corresponds to one tenth of the value of the crown. [JM]

57) P. GrossardT, "Der Ringer Maron und der Pankratiast 'Halter' in epigraphischen und literarischen Quellen", EA 34 (2002), p. 170-172 [BE 2003, 544]: The wrestler T. Aelius Aurelius Maron, victor in many agons, known from an honorary inscription in Seleukeia in Kilikia (SEG XLI 1407 A) [EBGR 1991, 79 and 212], can be identified with the Kilikian wrestler Maron in Philostratos (Gymnastikos 36), possibly also with an undefeated pankratiast from

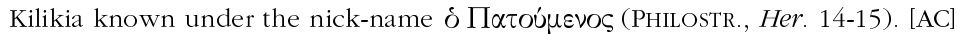

58) Chr. Haвіснт, "Danksagungen Geretteter an die Götter", Hyperboreus 7 (2001) p. 301-307 [SEG LI 2353; BE 2003, 192]: H. gives an overview of thanksgiving dedications addressed to a variety of divinities (e.g., Apollon Chresterios, Apollon Nisyreites, Asklepios, Athena, Helios, Herakles, Mes Axiottenos, Pan Euodos, Poseidon, Sozon, Theos Hypsistos, Zeus, the Egyptian gods) by persons who were saved from a great danger (4th cent. B.C.-3rd cent. A.D.; $I G$ II $^{2} 4323$, 4357, 4499; $I G$ X.2.1, 67; IG XII.1, 742; IG XII.5, 712.36; IG XIV 997, 2564; SEG XX 501; XXXII 790, 1084; XXXVI 555; XL 985; XLII 747; CIG 3669, 4838c; IGBulg I² 1; IGUR 193; I.Délos 2119, 2205, 2330, 2433; TAM II 900; V 179b, 442, 881; H. MALAY, Researches in Lydia, Mysia and Aiolis, Vienna, 1999, $\mathrm{n}^{\mathrm{os}} 118$ and 137; AvPergamon VIII.3, 63 and 71; I.Assos 28A; I.Stratonikeia 1101, 1104; SB 1054-1056, 2610, 3751, 4049, 4050, 7897, 8863, 8864; A. BERNAND, Le Paneion d'El-Kanais, Leiden, 1972, $\mathrm{n}^{\circ \mathrm{s}}$ 2, 8, 9bis, 34, 42; E. BRECCIA, Iscrizioni greche e latine. Catalogue general des antiquités égyptiennes du Musée d'Alexandrie, Cairo, 1911, $\mathrm{n}^{\circ} 121 ;$ Syll $^{3}$ 1173 , OGIS 69, 450; $L W 516)$. In many cases the danger is referred to in a general manner ( $\sigma \omega \theta \varepsilon i \varsigma$

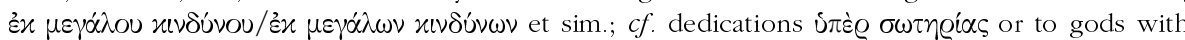
the attribute $\sigma \omega \tau \dot{n} \varrho)$. When the danger is specified, it usually concerns sea journeys, war, pirates' attacks, captivity, accidents, disease, and journeys in dangerous areas (e.g., the Troglodytike). [H. draws attention to the dedication of Aigai to Apollon Chresterios for its rescue which is ascribed

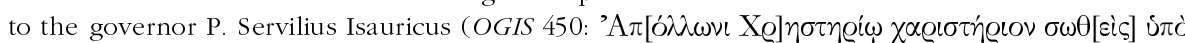

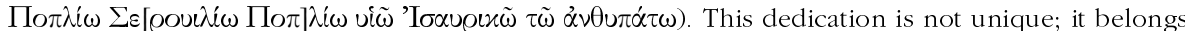
to a group of dedications in which the object of gratitude is both a divinity (especially Asklepios) and a human agent (especially a doctor); see supra ${ }^{\circ}$ 28]. See also the next lemma. [AC]

59) Chr. НАвіснт, "Weitere Weihungen Geretteter", Hyperboreus 8 (2002), p. 340-344: To the evidence discussed in supra $\mathrm{n}^{\circ} 58, \mathrm{H}$. presents three further thanksgiving dedications of persons who have been rescued from dangers. One of these texts is an unpublished dedication from Larisa (?, 2nd cent.); it was made by a group of men, possibly a commander and his soldiers

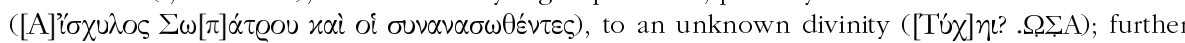
names were added by a different hand some time later. The other texts are a dedication from Kibyra (I.Kibyra 83) [cf. supra ${ }^{\circ} 28$ ] and a dedicatory epigram from Philomelion (I.Sultan Dagi $\mathrm{I}$ 44). [AC] 
60) C. Hasenohr, "Les monuments des colleges italiens sur l'" Agora des Compétaliastes "à Délos (II ${ }^{-} \mathrm{I}^{\text {er }}$ s. av. J.-C.)", in J.-Y. MARC - J.-C. MORETTI (eds), Constructions publiques et programmes édilitaires en Grèce entre le II siècle av. J.-C. et le Ir siècle ap.J.-C. Actes du colloque organisé par l'École Française d'Athènes et le CNRS, Athènes 14-17 mai 1995 (BCH Suppl. 39), Paris/Athens, 2001, p. 329-348 [SEG LI 993]: H. studies the dedications made by the religious associations of the Competaliasts and the Hermaists in the 'Agora des Compétaliastes' in Delos. The Ionic naiskos (cf. I.Délos 1734) cannot be interpreted as a temple of Hermes and Maia (according to R. VALLOIS, in EAD VII 1, p. 112-119) or as a temple of the Lares Compitales (as suggested by T. MAVROJANNIs; cf. EBGR 1994/95, 239). The inscription I.Délos 1731, written on an architrave, should be attributed to a Doric temple dedicated by the Hermaistai to Hermes and Maia. The monopteral tholos, to which I.Délos 1738 belongs, was regarded by J. HATZFELD as a temple of Hermes and Maia dedicated by the Hermaistai, since one of the dedicators (Aulus Cerrinius, L. f.) is known as a Hermaist (I.Délos 1734); N.K. RAuH interpreted the tholos as a temple of Herakles dedicated by the Competaliasts (cf. I.Délos 1746 and 1764), T. MAVROJANnis as a temple of Herakles dedicated by the association of the Olearii ( $c f$. I.Délos 1713/1714). Based on the observation that the dedicators of the tholos included freedmen and a slave and that a person (here, Cerrinius) could belong to different associations, H. identifies the dedicators as Competaliasts and the building as a temple of the Lares Compitales. A group of dedications (I.Délos 1744-1749) share as a common feature that the dedicators identified themselves simply by stating that they had dedicated another monument as well (e.g., of xaì tòv

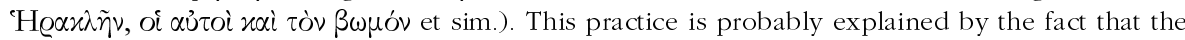
dedicators dedicated two objects (a statue and an altar) standing next to one another, but set a dedicatory inscription only on one of them. The altar of Maia (I.Délos 1744) may be connected with the inscribed base I.Délos 1750, the altar of Herakles (I.Délos 1746) with the statue dedicated by the Competaliasts (I.Délos 1764), and the Ionic naiskos of the Hermaistai (I.Délos 1734) with a statue of Hermes and Maia and with the altar I.Délos 1749. The formula oi waì was not used only by the Hermaistai, but by different associations. While the Hermaists made dedications only to Hermes and Maia, the Competaliasts addressed various gods. The dedicatory relief I.Délos 1745, which also refers to the dedication of statues of the $\theta$ coi (the Lares Compitales) and of a temple, should be attributed to Kompetaliastai. With regard to the interpretation of the monuments erected by the Italians on Delos, $\mathrm{H}$. observes that because of the heterogeneity of the Italian residents of Delos one should not apply here models known from Republican Rome; the Italians on Delos adopted monuments and practices of the Greek East (e.g., garland altars, Greek monopteral tholoi); it is doubtful whether the Agora of the Competaliasts is the result of a specific building program [see also C. HASENOHR, "L'Agora des Compétaliastes et ses abords à Délos: topographie et histoire d'un secteur occupé de l'époque archaique aux temps byzantins ", REA 104 (2002), p. 85-110]. [AC]

61) P. Herrmann, "Eine „pierre errante“ in Samos: Kultgesetz der Korybanten”, Chiron 32 (2002), p. 157-172 [BE 2003, 418]: Ed. pr. of a lex sacra (2nd cent.) seen for the first time in Samos in 1900 by L. BÜRCHNER, but originally from Asia Minor. The fragmentary text is a regulation $(\delta\llcorner\alpha \gamma \rho \alpha \varphi n)$ concerning the sale of a female priesthood for the cult of the Korybantes

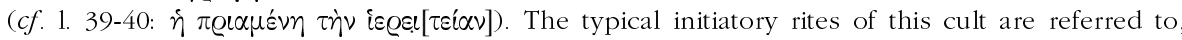

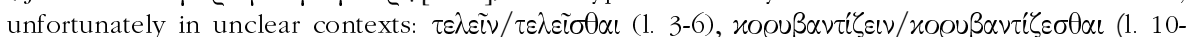

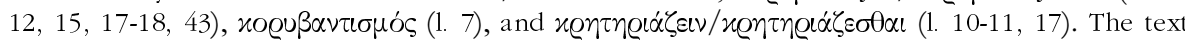

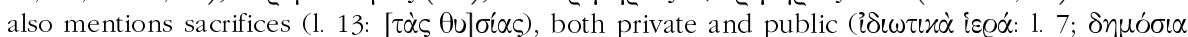

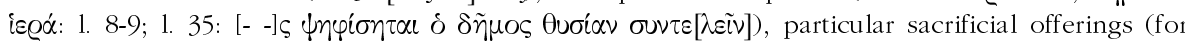

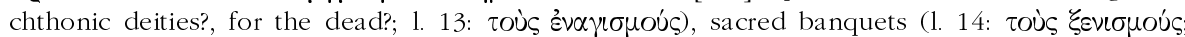

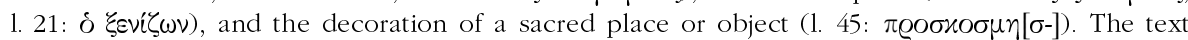

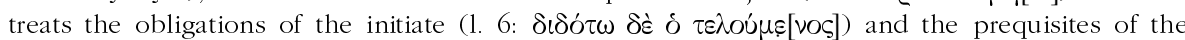
priestess $(1.6,15,18-19)$. Other priests and priestesses seem to have had the right to fulfill the

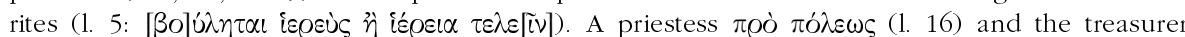
(1. 37) are mentioned in an unclear context. A particular section is devoted to the participation of

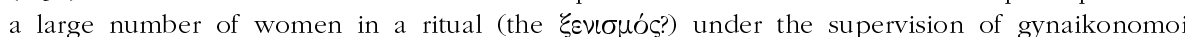
(1. 21-28). Finally, the text repeatedly mentions fines and sanctions (1. 20, 23, 25, 28, 30-31) and 


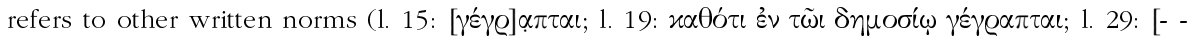

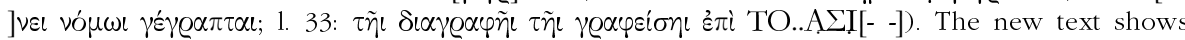
many similarities with the fourth century Erythraian lex sacra which concerns the cult of the Korybantes (I.Erythrai 206 + SEG XLVII 1628; cf. EBGR 1996, 273; 1997, 175) [see also supra $\mathrm{n}^{\circ}$ 32], of which H. presents the text and a German translation (p. 165-169); the most important differences are the mention of a ritual purification $(\lambda \circ u ́ \varepsilon เ \nu)$ and the role of both priests and priestesses in Erythrai. The similarities between the two texts, the dialect, and the existence of a priestess $\pi \varrho o ̀ ~ \pi o ́ \lambda \Xi \omega \subseteq ̣$ in Erythrai support the assumption that Erythrai is the provenance of the Samian stone. [JM]

62) P. Herrmann, "Magier in Hypaipa", Hyperboreus 8 (2002), p. 364-369: L. ROBerT (OMS VI, p. 137-160) had identified Artemis of Hypaipa (Lydia) with the Iranian goddess Anahita and argued that Iranian cult traditions survived until the 2 nd cent. A.D. To the evidence for $\mu$ '́ $\gamma \mathrm{O}$ !

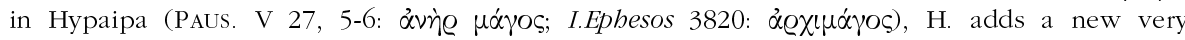
fragmentary inscription (2nd cent. A.D.), in which one recognizes a reference to $\mu \dot{\alpha} \gamma o$ (1. 8), a

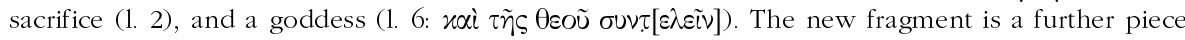
of evidence for Iranian elements in Lydia. [AC]

63) P. Herrmann, "Das hoıvòv $\tau \tilde{\omega} v$ 'I $\omega \dot{\nu} \omega \nu$ unter römischer Herrschaft", in Festschrift Deininger, p. 223-240 [BE 2003, 442]: Survey of the activities of the Koinon ton Ionon in the late Hellenistic and in the Imperial period, with particular focus on the festivals and agons organized by the Koinon (Panionia, Alexandreia), the officials of the Koinon and their cultic functions (basileus, archiereus ton Ionon, hiereus), and the emperor cult. [AC]

64) R. Норот, "Chronique d'étymologie grecque", $R P h 75$ (2001), p. 143: The word

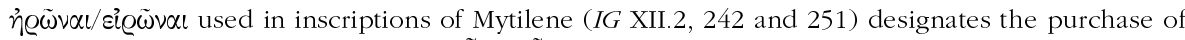

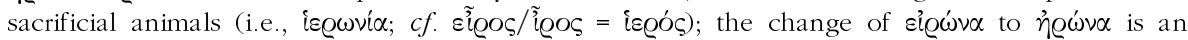
example of 'itacisme'. [AC]

65) A. Jacquemin, "Une nouvelle épiclèse de Poséidon à Delphes", BCH 126 (2002), p. 55-58: Ed. pr. of a dedicatory inscription found near the stadion in the sanctuary of Apollon at

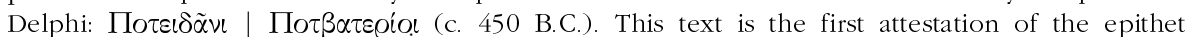

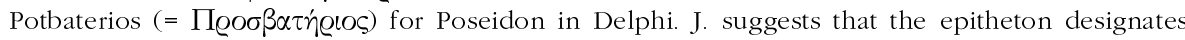
Poseidon as a divinity which enabled the access to the sanctuary las a patron of seafaring; $c f$. the

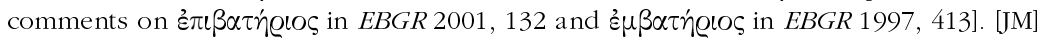

66) D. Jaillard, "A propos du fragment 35 de Callimaque", ZPE 132 (2000), p. 143-144: See infra $\mathrm{n}^{\circ} 115$.

67) C.P. JONEs, "Epigraphica", ZPE 139 (2002), p. 108-116 [BE 2003, 482]: J. suggests that Kar in an inscription from Stratonikeia (SEG XXXVIII 1100, 2nd cent.) should not be identified with Zeus Karios, but with the eponym of Karia, which is known only from literary sources. The inscription from Stratonikeia would then be the first epigraphical attestation of Kar; J. suspects some kind of an antiquarian or patriotic spirit behind this dedication. [JM]

68) D. JORDAN, "A Curse on Charioteers and Horses at Rome", ZPE 141 (2002), p. 141147 [BE 2003, 144]: J. discusses briefly a Greek defixio of 33 lines against charioteers and their horses found in Rome (early 4th cent. A.D.; $c f . E B G R$ 1998, $22=S E G$ XLVIII 1297). According to his new reading, the curse is directed against three charioteers of the blue faction (1. 20: Lampadius, Leontius, Lepas) and their horses (1. 13-19), three charioteers of the green or white faction (1. 21: Alcinus, Pansa, BevveteQ) and their horses (1. 22-25), and two charioteers of the red faction (1. 26: Curius, Lusor) and their horses (1. 26-28). J. also proposes a new reading of 1. 2-3:

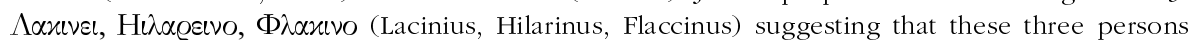
are cursed not as charioteers, but perhaps as the owners of the three blue teams. [JM]

69) M. Kajava, "When did the Isthmian Games Return to the Isthmus? (Rereading Corinth 8.3.153)", CP 97 (2002), p. 168-178: E. GEBHARD (EBGR 1994/95, 144) has demonstrated that the Isthmian festival, which was transferred to Sikyon after the sack of Korinth in 146 
B.C., returned to Korinth's control almost immediately after the foundation of the colony (40 B.C.?); GEBHARD suggested that the agon was held in Korinth until c. A.D. 50-60. The agonothetes of the first Isthmian contest celebrated in Isthmus after the return of the games to the sanctuary of Poseidon is known from an honorific inscription (Corinth 8.3.153; 1. 6-8: [agonothete I] sthmion et Caesar[eon, qui Isthm]ia ad Isthmum egit [primus sub cura]m col(oniae) Laud(is) Iul(iae) Cor(intbiensis)). J.H. KENT identified this person as [L. Castri]cius Regulus, duovir quinquenalis in c. A.D. 21/22. GEBHARD favored an identification with Cn. Publicius Regulus (c. A.D. 50-60) and restored [Claudi]on in 1. 5. KAJAVA plausibly argues that this inscription should be dated shortly after Livia's deification, when a competition in her honor was introduced to the program of the games (1. 9: [carmina ad Iulia] $m$ diva[m Au]g(ustam)). He recognizes in the agonothetes of the first Isthmia in Isthmus Cn. Cornelius Pulcher, known as an agonothetes from F.Delphes III.1, 534 (c. A.D. 45). According to the Delphic inscription, during his agonothesia the festival included for the first time an equestrian event for maidens, which may be identified with the contest mentioned in the Korinthian honorific inscription (1. 9-10: virgi[numque certame]n instituit). Consequently, the Isthmian games returned to Isthmus in A.D. 43. In 1. 8 K. restores [primus omniulm (not sub cura]m col(oniae)). Pulcher, who also served as agonothetes of the Claudia Sebasta, was also responsible for the re-organization of the celebration of the Caesarea in Korinth, which included sacrifices and a banquet (1. 10-13: omnib[us caerimoniis Cae]sareon novatis Coo[rinthi sacra vo] to peregit epulumq(ue) [omnibus co]lonis dedit). [AC]

70) M. Kajava, "Eueteria Sebasta in Mytilene", Latomus 61 (2002), p. 919-928: Eueteria Sebasta in an inscription from Mytilene (IG XII.2, 262) has been interpreted as the equivalent of Abudantia Augusta or Annona Augusta. K. proposes a new restoration of the text as a dedication

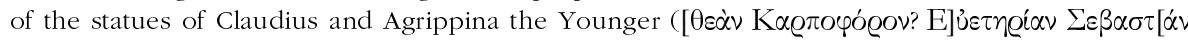

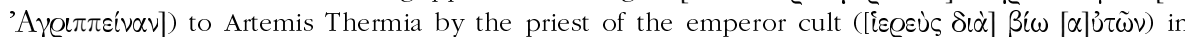
accordance with divine command $\left([\varkappa \alpha] \tau^{\prime} \dot{\varepsilon} \pi \tau \tau \alpha \gamma \alpha \dot{\alpha}[\nu]\right)$. Agrippina is known to have been associated with Demeter and to have been worshipped as Thea Aiolis Karpophoros. [AC]

71) M. Kajava, "Eresian Memories", ZPE 139 (2002), p. 89-107: K. studies several inscriptions from Eresos on Lesbos related to the imperial cult and attesting dedications made by Caius Cornelius, son of Zoittas, P. Quintilius (Varus?), Damarchos, son of Leon, an unknown archiereus, and the Eresian demos. The author associates $I G$ XII 2, 573 and more cautiously $I G$ XII Suppl. 124 with the activities of Caius Cornelius, known as the dedicant of an edifice [a temple?] to Augustus and the Eresian demos (IG XII 2, 536). If this attribution is correct, then Caius Cornelius must have been one of the most important supporters of the imperial cult on the island in the early Imperial period, having dedicated a sanctuary and a temple to C. Caesar and L. Caesar, a sanctuary and a temple to Livia Sebasta Pronoia, and temples to Augustus. [JM]

72) Chr. Karadima-Matsa - K. Clinton, "Korrane, a Sacred Woman in Samothrace", ZPE 138 (2002), p. 87-92 [BE 2003, 421]: Ed. pr. of a grave stele (Samothrake, 2nd cent.

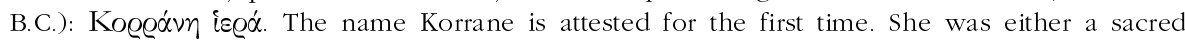
dancer in the Samothrakian Mysteries, like the dancers depicted on the frieze of the so called "Hall of the Choral Dancers" (formerly "Temenos") or a manumitted slave, who had been dedicated to the Samothrakian Great Gods and did her service in the sanctuary. The authors seem to prefer the first hypothesis [but see Ph. GAUTHIER, BE 2002, 421]. [JM]

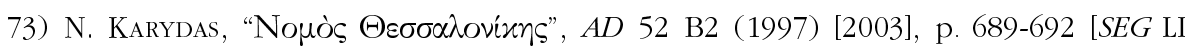
890]: Ed. pr. of a funerary stele set up by a couple for its alumna (Thessalonike, Imperial period, p. 691). The stele is decorated with the representation of Aphrodite. [For the association of heroised women with Aphrodite see, e.g., I.Beroia 214, 244, 284, 354, and 508 (3rd cent. A.D.)]. $[\mathrm{AC}]$

74) D. KnibBe, "Private Evergetism in the Service of the City-Goddess: The Most Wealthy Ephesian Family of the 2nd Century CE Supports Artemis in her Struggle Against the Decline of her Cult after the Meteorological Catastrophe of 186 CE", MedAnt 5.1 (2002), p. 49-62: K. presents an overview of the measures taken in the 2nd cent. A.D. to stengthen the cult of Artemis in the context of the competition among sanctuaries and 
cults in the 2nd cent. A.D. These measures included the transformation of Artemis' altar near the crossway to Ortygia into a monumental cenotaph for the emperor Lucius Verus, the extension of the ekecheiria during the entire month of Artemision (I.Ephesos 24), the celebration of the birthday of Artemis on the sixth day of every month (SEG XXXIX 1195), the perception of the goddess as helper against pestilence (SEG XLI 981), and the roofing of the processional way to the Artemision, funded by T. Flavius Damianus (PHILOSTR., vit. Soph. II, 23 p. 107 K), one of the great benefactors of Ephesos. The latter project became an urgent necessity after the climatic changes which were caused by a volcanic eruption in New Zealand in A.D. 186; the processional way had to be sheltered from heavy rainfalls. [AC]

75) D. Knoepfler, "Oropos et la Confédération béotienne à la lumière de quelques inscriptions « revisitées »", Chiron 32 (2002), p. 119-155 [BE 2003, 332]: Among other important issues concerning the significance of Oropos in the context of the Boiotian Koinon $\mathrm{K}$. also discusses briefly the role of the sanctuary of Amphiaraos. K. demonstrates that the erection of proxeny decrees of the Boiotion Koinon in the Amphiareion does not in any way imply that this sanctuary functioned as a federal cult place; moreover, these decrees were erected in a short period of time (the last three decades of the 3rd cent. B.C.), in which Oropians were holding important positions in the administration of the federation. [JM]

76) D. KNoepfler, "Loi d'Érétrie contre la tyrannie et l'oligarchie", BCH 126 (2002), p. 149-204: K. completes his study of the two fragments of the Eretrian law against tyranny and oligarchy (Eretria, c. 340 B.C.; $c f . E B G R$ 2001, 97) with the presentation of fr. B 17- 36, a restoration of fr. A, and thorough commentary. According to K.'s restoration of A 7-9, the tyrannicide, if a citizen, was honored with an erection of his statue next to an altar (?) and with prohedria in all the agons of the city. The new fragment (B 25) mentions an Agoraion, which should probably be interpreted as a sanctuary of Zeus Agoraios; in case of an oligarchic revolt the people are urged to occupy the Agoraion, in the section of the city where normally the meetings of the council were held. [AC]

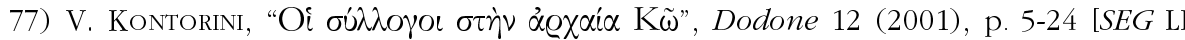
1048; $B E$ 2002, 319]: K. gives a useful overview of the epigraphic evidence concerning the cult and professional associations in Kos (3rd cent. B.C.-3rd cent. A.D.), their organization and

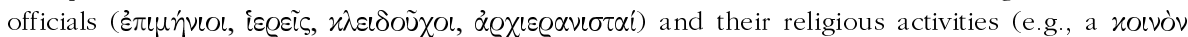

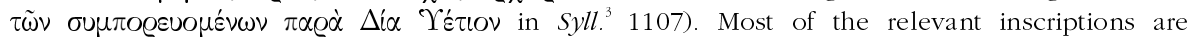

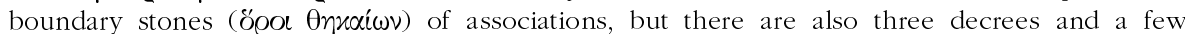

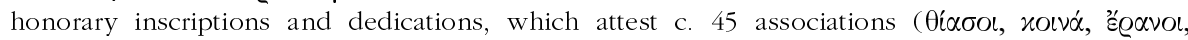

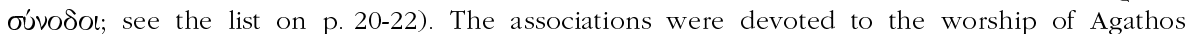
Daimon, Aphrodite, Aphrodite Eudie, Apollon, Athena, Athena Lindia, Bakchos, Helios, Hera Ourania, Hermes, Poseidon Asphaleios, Zeus Atabyrios, Zeus Hyetios, Zeus Hypsistos, Zeus Soter, Augustus Mercurius, the Egyptian deities, and Astarte. We single out an association of women for

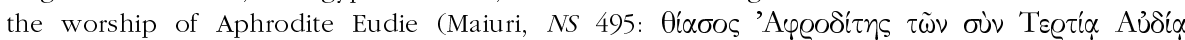

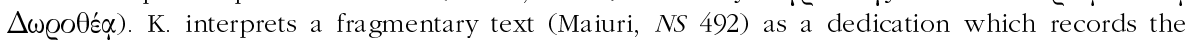

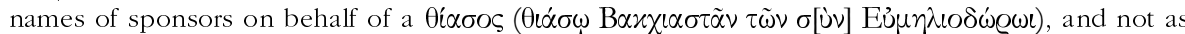
the boundary stone of a burial place (p. 7); we note here the interesting theophoric name Eumeliodoros which derives from Eumelios, a Koan patron of livestock. The founder of an association of Hermaistai was the son of a man with the theophoric name Hermaios ( $P H$ 156). $[\mathrm{AC}]$

78) E. Kosmetatou, "Remarks on a Delphic Ptolemaic Dynastic Group Monument", Tyche 17 (2002), p. 103-111: K. argues that the statues of PTOLEMY III Euergetes and his family to Apollon Pythios at Delphi (IG IX.1 ${ }^{2}$ 202) were dedicated by an Aitolian (Lamios?) as an expression of gratitude towards the king for financially (?) supporting the Aitolian League. [JM]

79) E. Kosmetatou, "The Athenian Inventory Lists: A Review Article", AC 71 (2002), p. 185-197: In her critical review of the book of D. HARRIs, The Treasures of the Parthenon and Erechtheion, Oxford, 1995 [cf. EBGR 1994/95, 157; 1997, 228], K. focuses on the mention of coins in these inventories ( $c f$. EAD., "A Numismatic Commentary of the Inventory Lists on the Athenian 
Acropolis", Rev. Belge de Num. 147 [2001], p. 11-37), on the historical context of a dedication

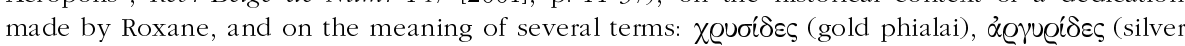

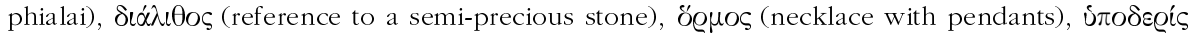
(necklace composed of beads at the base of the throat), $\pi \varepsilon \varrho ı \varrho \alpha \chi \eta \lambda i \delta$ เov (cross-bands of a breast-

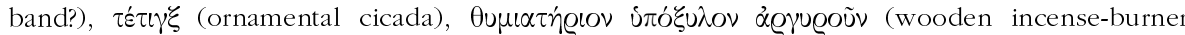

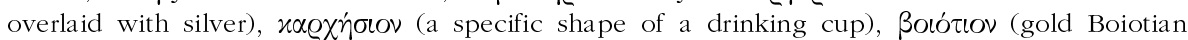

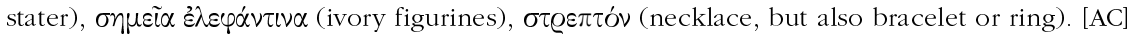

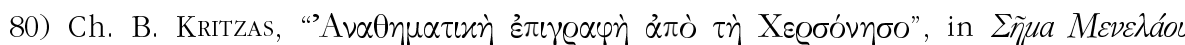

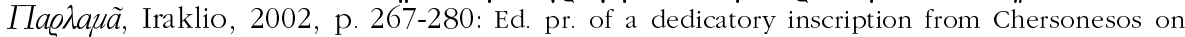
Crete (2nd cent. A.D.). It reports that Chryson dedicated ( $(\alpha \theta \varepsilon \dot{\varepsilon} \varrho \omega \sigma \varepsilon v)$ together with his wife and his children the temple of an anonymous deity, together with the cult statue and a porticus ( $\tau$ òv

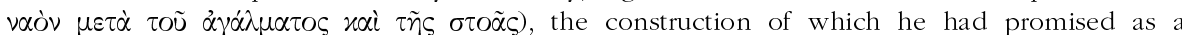

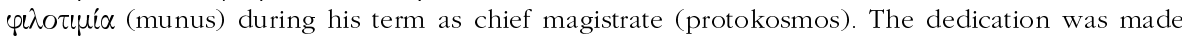

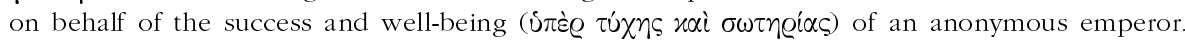
$[\mathrm{AD}]$

81) A. ŁAJTAR, "Bemerkungen zu griechischen Inschriften aus Ägypten", ZPE 140 (2002), p. 99-101: Discussion of theophoric names in an Egyptian inscription of unknown provenience (SB I 5980, 2nd/3rd cent.): Sarapion, Dioskouros, Isidoros, Athenodoros, Ammonios, Anoubion, Apollonios. Because of the name Antinoos (or Philantinoos) $\ell$. attributes the inscription to Antinoopolis in central Egypt. On a funerary stele for a family from Tenuthis now in the Kestner Museum in Hannover (inv. 1925.225; 2nd cent. A.D.) one recognizes four theophoric names (Herakleia, Herakloun, Hermias, Apollonarion). [JM]

82) A. ŁaJTAR, "Eine jüdische Inschrift aus Antiochia in Syrien", ZPE 140 (2002), p. 101$102[B E 2003,559]$ : The letters $\Gamma_{0} \Lambda \mathrm{B}$ next to a menorah depicted on a stone at Antiocheia ( $B E$ $1938,505)$ were interpreted as a Semitic name, a profession or, a date. According to $€$. $\Gamma_{0}$ is an abbreviation for oujprial (known from alchemist sources) and $\lambda \beta$ is the numeral 32. A small golden object (perhaps the depicted menorah) weighed 32 ounces, or somebody donated 32 ounces of gold for the gilding of a menorah. [JM]

83) S.D. LAmBerT, "The Sacrificial Calendar of Athens", ABSA 97 (2002), p. 353-399: L. offers an invaluable study of the sacrificial calendar of Athens, which was produced in two stages, between $410 / 9$ and 405/4 and 403/2 and 400/399 B.C. The study includes a technical description and a new critical edition of the text, commentary, translation, and brief explanatory notes. Thirteen fragments of white marble can be attributed to the calendar [we adopt the numbering of L.]. On face A the text is in Ionic script (later stage), on face B in Attic script (earlier stage). Fragments of headings on face A show that the text was arranged in annual and biennial sequences, but there must have existed arrangements for quadrennial festivals and such that took place at longer intervals. Within these sequences sacrifices and other issues are listed in chronological order, month by month and within a month, day by day. In addition to these headings there is a third type of heading which specify the source of authority for the items

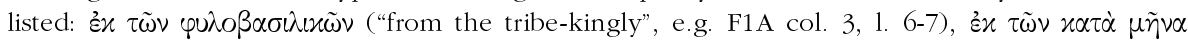

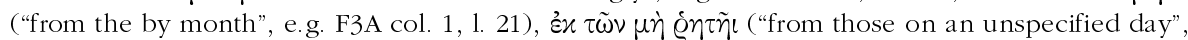
e.g. F1A col. 3, 1. 24). In his explanatory notes L. lists and discusses briefly the sacrificial animals (sheep, rams, lambs, cows, sows, piglets), the non-animal offerings (barley, wine, olive oil [restored], honey, wood), and the payments made to officiants (payments in kind or in lieu and monetary payments [bierosyna for priestesses and apometra for priests or priestesses]). [JM]

84) S.D. LAMBERT, "Parerga I: $I G \mathrm{I}^{3}$ 240K, a Fragment of $I G \mathrm{I}^{3}$ 1185?", ZPE 139 (2002), p. 69-71 [BE 2003, 242]: IG $\mathrm{I}^{3} 240 \mathrm{~K}$ does not belong to the sacrificial calendar of Athens (410/9400/399 B.C.; S. Dow, "Greek Inscriptions", Hesperia 10 [1941], p. 31-37; "The Walls Inscribed with Nikomakhos' Law Code", Hesperia 30 [1961], p. 58-73), but perhaps is part of a funerary monument of the period of the Peloponnesian War (IG $\left.\mathrm{I}^{3} 1185\right)$. [JM] 
85) S.D. LAMBERT, "Parerga II: The Date of the Nemean Games", ZPE 139 (2002), p. 7274 [BE 2003, 242]: After offering a new restoration of 1.10 (instead of $[\Delta] i \mathrm{~N} \varepsilon\left[\alpha v^{\prime} \alpha l\right]$, L. reads $[\Delta] i \mathrm{~N} \varepsilon[\mu \varepsilon \dot{\varepsilon} \omega t])$ in a fragment of the sacrificial calendar of Athens as inscribed in the second phase of the work of Nikomachos' commision (403/2-400/399 B.C.; S. Dow, "Greek Inscriptions", Hesperia 10 [1941], p. 31-37, fr. F) L. confirms the assumption of P. PERLMAN [EBGR 2000, 154] that the Nemean Games took place in late summer. According to the reconstruction of L. there was a shrine of Zeus Nemeos in Athens at which offerings took place in the month Metageitnion on the setting out of the Nemean theoria. [JM]

86) S.D. LamberT, "Parerga III: The Genesia, Basile and Epops Again", ZPE 139 (2002), p. 75-82 [BE 2003, 242]: L. relates a part of fragment 1 of the sacrificial calendar of Athens to the Genesia, a hypothesis already proposed by S. Dow in an unpublished paper. In 1.2 the author restores $\Sigma \varepsilon[\mu \nu \tilde{\omega} \nu \theta \varepsilon \tilde{\omega}] \nu$, suggesting that the famous procession for the Semnai might have taken place one day before the beginning of the Genesia. According to L., the Genesia could have been a rite celebrated both at the level of polis subgroups and at the level of the city. Analogous to the sacrifice to Erechtheus (1. 5) during the state Genesia, L. suggests that in Erchia a similar sacrifice in honour of the hero Epops took place during the local Genesia. L. links the Erchian sacrifice offered to Basile to the local Genesia. In a brief appendix L. suggests a new

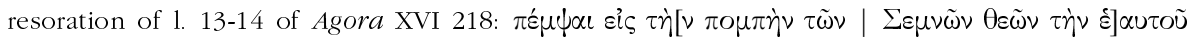

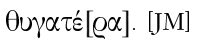

87) H. Lauter, “„Polybios hat es geweiht...". Stiftungsinschriften des Polybios und des Philopoimen aus dem neuen Zeus-Heiligtum zu Megalopolis (Griechenland)", $A W 33$ (2002), p. 375-386: Three different series of stamped roof tiles bearing inscriptions (2nd cent. B.C.), can be identified as dedications of important personalities of Megalopolis to the sanctuary

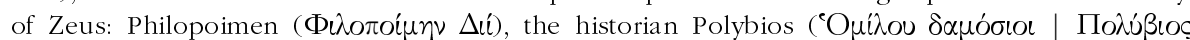
¿'vé $\theta \eta x \varepsilon$; "(from the workshop) of Homilos; public (roof tiles); Polybios dedicated them), and

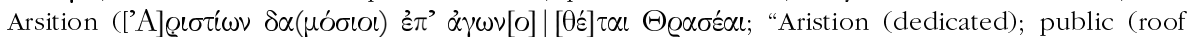
tiles); during the agonothesia of Thraseas). [JM]

88) F. LeFÈvre, Corpus des Inscriptions de Delphes. Tome IV. Documents amphictioniques avec une Note d'architecture par Didier LAROCHE et des Notes d'onomastique par Olivier MASSON, Paris, 2002 [BE 2002, 208]: The new volume of the Delphic corpus presents new critical editions of the documents of the Delphic amphictyony with detailed commentaries. In the short introductory chapters, L. briefly treats the history of the institutions of the Delphic amphictyony (p. 3-4) and the complex problems of chronology (13-30). In a post-scriptum (p. 459-468) he presents a critical review of the book of P. SANCHEZ, L'Amphictionie des Pyles et de Delphes. Recherches sur son rôle historique, des origines au II siècle de notre ère, Stuttgart, 2001 (cf. EBGR 2001, 163). The inscriptions are presented in a chronological order (4th cent.: 1-11; c. 278-190: 12-102; 2nd-1st cent.: 103-131; Imperial period: 132-169; incerta: p. 385-397). The corpus includes the following groups of texts. Leges sacrae and administrative regulations: The most important text is the amphictyonic lex sacra which contains the oaths of the federation's magistrates (1. 3-13) and regulations concerning a variety of subjects related to the administration of the amphictyony, the sacred land of Apollon, a ritual bath (?, $\lambda \tilde{\omega} \tau \iota c)$, and the festival of the Pythia $\left(1=C I D\right.$ I 10,380 B.C.). To the fragmentary decree or law n ${ }^{\circ} 2(=S E G$ XLV 469 , ca. 400350 B.C.), which has been summarized in $E B G R$ 1996, 241, L. adds seven new small fragments, which, however, do not contribute to a better understanding of the text. A fragmentary lex sacra $\left(4=I G \mathrm{II}^{2} 1127\right.$, ca. 350 B.C.) treats the subject of manslaughter and seizures. Other amphictyonic decrees concern the protection of visitors of the sanctuary and the protection of the sacred land and the mountains from fire $(51=\operatorname{SEG}$ XVIII 243 , c. 250-220), prohibit the unauthorized setting up of dedications, the erecting of tents, and the making of fire in the porticus of King Attalos I $(85=$ LSCG Suppl. 43 , late 3rd cent. $)$, and delimitate pasture land for the sacred livestock $(108=$ LSCG 79, c. 220-217 B.C.). Several documents (judgments, letters, etc.) stem from disputes between cities with regard to their representation in the amphictyony (Sparta and the Dorians: 110; the Euboian cities: 121-122; Thronion and Skarpheia: 123-126); a fragmentary letter of Licinius also seems to deal with the issue of the amphictyonic votes $(105,186$ ? B.C.). A fragmenta- 
ry document concerns the creation of the board of treasurers ( $9=$ CID II 74 I, 337 B.C.), another

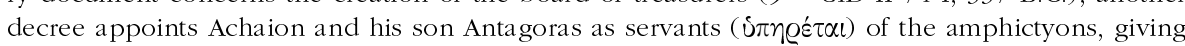
them the same security as the one guaranteed to the herald of the amphictyons (43, c. 260 B.C.). The longest text is a dossier of documents concerning crimes against the sanctuary (119, ca. 120115 B.C.); it consists of a fragmentary letter of a Roman magistrate (A), a list of the hieromnemones and the pylagorai (B), the oath of the hieromnemones (C), documents concerning an estimate of the money missing from the sacred revenues and owed to the sanctuary ( $\mathrm{D}, \mathrm{F}, \mathrm{G}, \mathrm{H}, \mathrm{I})$, a verdict of the amphictyons concerning the borders of the sacred land (E), and a list of objects (J). A letter of a Roman governor informs the amphictyony about Domitian's decision that the Pythian contest should be performed in accordance with the traditional amphictyonic laws (142). One of the most important documents for the amphictyony in the Imperial period is Hadrian's letter to Delphi (152, A.D. 125; cf. 152 bis), in which he reforms the rules under which the Pythian contest should take place and passes a judgment concerning the representation of Greek cities in the amphictyony. A letter of Adeimantos to King Demetrios Poliorketes concerns the relations between the king and the amphictyony (11 = SEG XLV 479); a letter of the consul Spurius Postumus recognized the asylia of the Delphic sanctuary (104, 189 B.C.). Two documents concern the associations of Dionysiac technitai: A decree introduces sanctions against members of the association of the Dionysiac artists of Isthmos and Nemea in case of unexcused absence from the trieteric contest for Dionysos Kadmeios in Thebes (71, c. 228-222 B.C.; cf. 72); another document is connected with the dispute between the associations of Dionysiac technitai in Athens and those in Nemea and Isthmos (120, late 2nd cent.; $c f$. the asylia decrees for the Dionysiac artists in Athens, $\mathrm{n}^{\text {os }}$ 114-115, and two honorific inscriptions for the Athenian association of Dionysiac technitai, $\mathrm{n}^{\text {os }} 12$ and 117). The decrees or laws $\mathrm{n}^{\text {os }} 3,5,8,21$ (concerning sacred property), 78 (concerning the house? of the Thebans; $c f$. EBGR 1990, 73), 80, and 83 are too fragmentary. Other public documents include a fragmentary decree concerning an alliance (?) between Athens and the Aitolians (30), a decree concerning the acceptance of the Attic tetradrachme (127), and a fragmentary decree (?) concerning a judicial procedure (387-388 n ${ }^{\circ} \mathrm{B}$, 4th cent.).

Asylia decrees: for the sanctuaries of Athena Itonia in Koroneia (38), Dionysos Kadmeios in Thebes (70; cf. 72), Apollon Ptoios in Akraiphia (76), the Muses (?) in Thebes (77), Athena Nikephoros in Pergamon (107), for the cities of Teos (97) and Antiocheia of the Chrysaoreis (99), and for the Dionysiac artists in Athens (114-115, 134 or 130 B.C.); $c f$. a decrees concerning the recognition of the festivals of the Ptolemaia in Alexandria (40, 266 or 262 B.C.). Accounts and inventories: An account lists the necessary construction works for the preparation of the Pythia (57, c. 251 ); a fragmentary inventory (p. 385-387 $\mathrm{n}^{\circ}$ A) may be related to the Third Sacred War. Building inscriptions: They record the constructions and repairs of supporting walls (139-140), a fountain (Kassotis?; 141), the house of the Pythia (146), a library (147), the sanctuary of Asklepios (154), and the enigmatic stuctorium (148) from revenues of Apollon. Lists: of Amphictyonic magistrates $(16,29,34,36-37)$, participants in the Soteria (technitai: 31, 42; other participants: 45 , $47-48,53,55)$, and victors at the Soteria $(61,67,73,75,79,84,94)$. Honorary inscriptions: Most of the amphictyonic documents are honorary decrees and honorific inscriptions. They honor cities (Megalopolis and Messene: 7), boards of hieromnemones (28, 33, p. 389-390 $\mathrm{n}^{\circ} \mathrm{D}$ ) and individual hieromnemones (of Chios: 64-65, 86-93, 101; Athens: 95, 134-135; Thessaly: 106; Magnesia on the Maeander: 100), other persons in the service of the Amphictyony (agonothetes of the Pythia: 156, 163-164; amphiktyon: 145; epimeletes: 165; bierokeryx: 56; hieros pais: 155; bypogrammateus: 46; byperetes: 52), Roman generals, magistrates, and governors (103, 129, 143, 166, 169), emperors and members of the imperial family (132-133, 136-138, 149-150, 153, 168), a Helladarches (161), a high priestess of the Achaian Koinon (162), individuals from various cities (Aigion: 68; Alexandreia Troas: 63; Argos: 14-15, 20, 27; Athens: 6, 49, 56, 59-60, 62, 112-113, 159-160; Chaironeia: 151, the philosopher Plutarch; Bouttos: 23; Delphi: 167; Kos: 96; Elis: 25; Eretria: 18; Herakleia: 24; Kamarina: 35; Knidos: 25, 26, 130, 131; Lamia: 39, 52; Larisa: 128; Megara: 22; Mylasa: 101, a descendant of Mausolos; Naupaktos: 54; Pellene: 41; Tyrbeion: 23; unclear: 13, 66, 74), the Athenian association of Dionysiac technitai (12, c. $278 ; 117$, c. $121-117$ B.C.); $\mathrm{n}^{\text {os }} 32$ and 116 are fragmentary. We single out the honorary decree for Aristotle and Kallisthenes for the composition of the list of the victors at the Pythia (10, c. 337-327), for the Koan doctor Philistos (96), for other 
specialists (scholars and artists), who gave lectures or performed during competitions (kitharode: 49; philosopher: 63; sophist: 157-158; unclear: 17), and for Antiochos III and Laodike (98). A particularly interesting group of decrees honors persons, who denounced the theft of sacred money $(14-15,20,22-23,25,41$; c. $277-260$ B.C.) and other crimes against the sanctuary (118), as well as a Roman magistrate, who punished persons involved in a sacrilege and in crimes against the sanctuary (169). Among the honorands we also mention persons who engaged in building works and the better performance of festivals. These services include the construction of a road

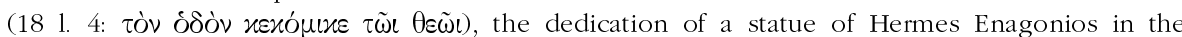
Pythian stadion (26), the construction of the xóouos for Athena Pronaia (39 and 54), and the donation of ten decorated shields for the more glamorous performance of the athletic contest of the Pythia (27). We single out the case of the architect Damon (44), who represents the third generation of architects of the temple belonging to the same family.

We remark a few interesting details. The Chremonidean War hindered the meeting of the Amphictyons at Thermopylai (36, c. 266-260), an interesting case in which wars influenced the performance of rituals [cf. L. ROBERT, Études anatoliennes, Paris, 1937, p. 426-429 and A. Chaniotis, War in the Hellenistic World: A Social and Cultural History, Oxford, 2005, p. 162]. In the honorary decree for the architect Damon L. draws attention to the expression $\tau \dot{\eta} \nu$

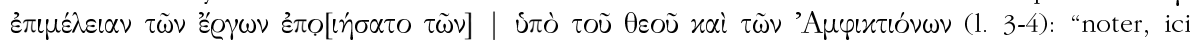
comme dans le $\mathrm{n}^{\circ} 27,1.8$, la fiction du dialogue avec la divinité, dans lequel les Amphictions ne sont qu'un intermédiaire. Dans le cas présent, y a-t-il une allusion indirecte à un oracle...?" (p. 153). [An oracle giving instructions concerning the construction of the temple is quite probable; $c f$. I.Milet 935: the builders of a part of the theater asked Apollon whether they should continue the difficult task of building arching vaults, or rather dedicate themselves to another construction ( $c f . E B G R$ 1998, 121). The situation in $\mathrm{n}^{\circ} 271.8$ is somewhat different, since it does

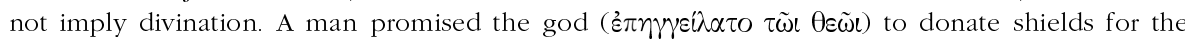
Pythia; he probably announced his promise in a ritual space (in the temple?, in front of Apollon's statue?)]. In the honorary decrees $\mathrm{n}^{\mathrm{os}} 46,49,52,56,59-60$, and $62-63$ one notes the particular type of the crown: $\delta \alpha \dot{\alpha} \nu \eta\rceil \subseteq \sigma \varepsilon \varphi \dot{\alpha} \nu \omega \iota \tau \tilde{\eta} \varsigma \pi \alpha \varrho \dot{\alpha} \tau O \tilde{u} \theta \varepsilon o \tilde{u}$, i.e. a crown made not of any laurel, but from

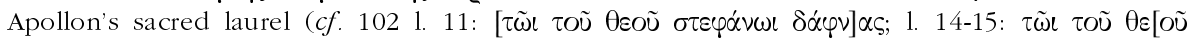

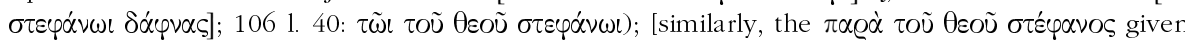
to a benefactor by the priest of Dionysos in Ilion (EBGR 1999, $201=$ SEG XLIX 1753) may be a crown made from ivy cut in a sanctuary of Dionysos]. The particular attention given to crowns is also demonstrated by the request of the Dionysiac technitai of Athens to receive a guarantee of the right of their priests to wear the traditional golden crowns in every city (117 1. 26:

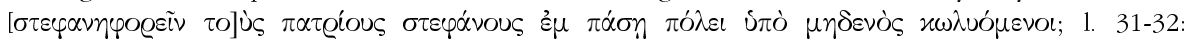

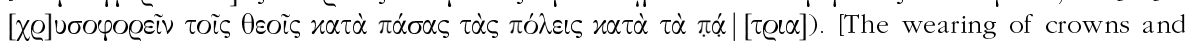
other insignia was subject to permission by the city authorities; e.g., the Athenian hieromnemon Demetrios was allowed to wear the gold crown awarded to him by the amphictyony only during the sacred days of the Pythias (134, A.D. 27 or 31). For insignia of office see A. ChanioTis, "Griechische Rituale der Statusänderung und ihre Dynamik", in M. STEINICKE - S. WeINFURTER (eds), Investitur- und Krönungsrituale, Cologne/Weimar 2005, p. 49-52; for crowns cf. MAMA

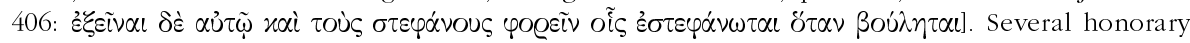
decrees for the hieromnemones of Chios provide for the announcement of the honors in Chios in the theater, during the Dionysia, "when the choruses of the boys are about to compete" (86-88; no reference to the precise moment of the announcement in $n^{\text {os }} 65$ and 89). (One expected a full house during the performance of the choruses of boys (cf. e.g. I.Kyme 13 I); for other examples for distinctions between particular types of crowns and announcements see A. CHANIOTIS, "Theatre Rituals", in P. WILSON (ed.), The Epigraphy of Greek Theatre, Oxford, forthcoming]. The honorary decrees for the hieromnemones Polyarchides and Leochides (86-87) are illustrative examples of typical duties and activities of the hieromnemones: "he jointly performed

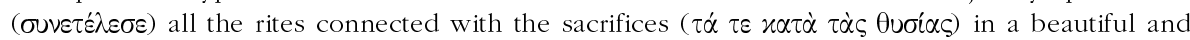

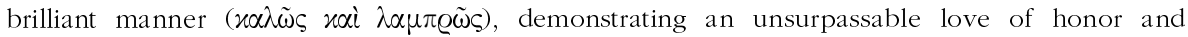

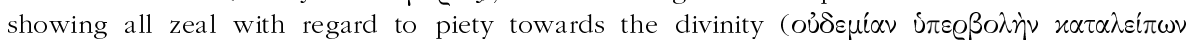

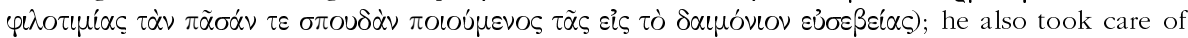


the dedications, the altar and all the other objects dedicated by the city of the Chians; and together with his fellow hieromnemones he resolved some of the legal conflicts through

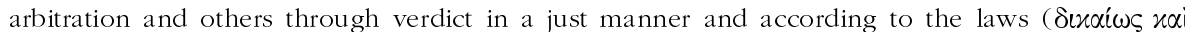

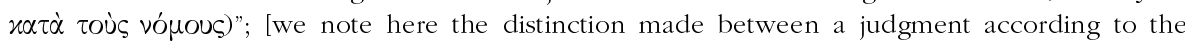

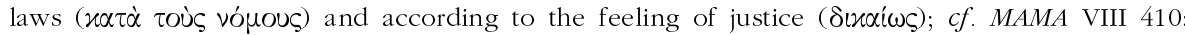

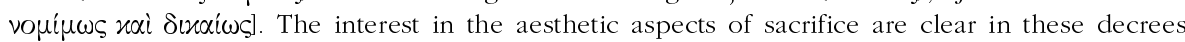

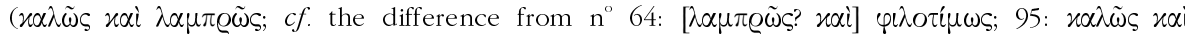

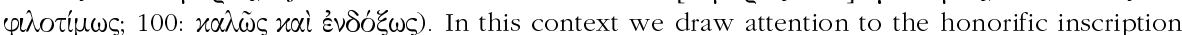
for an amphictyon who contributed to the performance of the Great Pythia in a solemn manner

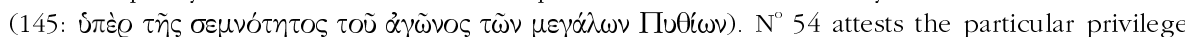

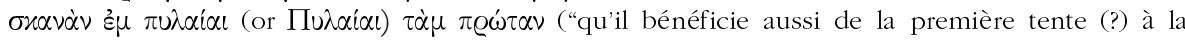
pylée (aux Pyles?)"), possibly a prerogative in the distribution of sacrificial meat. The asylia decree for Antiocheia of the Chrysaoreis (99) is a nice example for the reception of the victors in their home town; the ambassador of Antiocheia, Pausimachos, who was also a victor at the Soteria, was honored by the Amphictyones with a crown; this honor was to be publicly

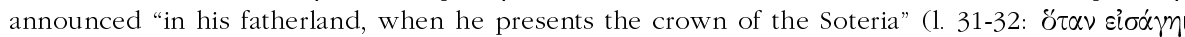
$\tau \dot{v} v \tau \tilde{\omega} \nu \sum \omega \tau \eta Q^{\prime}\left(\omega \nu \sigma \tau \varepsilon^{\prime} \varphi x \nu O \nu\right)$. The award of a kerykeion sealed with the seal of the amphictyons to benefactors of the amphictyony $(14,27,41)$, in order to provide security to these persons in their travels, is relevant for questions of mobility and the reputation of the sanctuary as a warrant of safety. [Cf. the remarks of Ph. GAUTHIER, BE 2002, 208] [AC]

89) B. Le GuEn, Les associations de technites dionysiaques à l'époque hellénistique, Nancy, 2001 [SEG LI 2279; BE 2002, 500; 2003, 300]: This is a comprehensive study dedicated to the associations of Dionysiac artists. The first volume of the work presents an overview of research and of the sources as well as an introduction to the corpus of relevant testimonia (p. 9-34). The body of this volume (p. 41-326) consists of a corpus of 78 inscriptions (p. 41-336) and a few literary texts (p. 331-349), presented in critical edition, French translation, and commentary. In addition to the Eretrian law concerning the Dionysia (1), the documents concern the history and activities of the associations in Athens (2-16), Isthmos and Nemea (1737), Ionia and Hellespontos (38-59), Egypt and Cyprus (60-71), Sicily and Italy (72-77), and Rhodes (78). The second volume presents a systematic survey of this material, in which L.G. discusses the history of the associations (p. 5-40), their organisation (recruitment, membership, officials, salaries, seat, assembly; p. 41-82), their cultic activities (p. 83-93), their finances (p. 95104), and the professional specialisation of their members (p. 105-132). [Cf. the review of J.R. GREEN, Topoi 11 (2001), p. 809-813, the remarks of S. FOLLET, BE 2003, 300, and the systematic study by S. ANEZIRI, Die Vereine der dionysischen Techniten im Kontext der hellenistischen Gesellschaft. Untersuchungen zur Geschichte, Organisation und Wirkung der hellenistischen Technitenvereine, Stuttgart, 2003]. [AC]

90) C. LeHMER - M. WÖRRLE, "Neue Inschriftenfunde aus Aizanoi III: Aizanitica Minora I", Chiron 32 (2002), p. 571-646 [BE 2003, 506]: Ed. pr. (and in part improved edition) of funerary inscriptions found at Aizanoi and in the Aizanitis (2nd-3rd cent.). In $\mathrm{n}^{\circ} 1$ the deceased person is designated as a $\ddot{n} \varrho \omega c$. $\mathrm{N}^{\circ} 2$ is a bilingual inscription beginning with $\mathrm{D}$ (is) M(anibus)

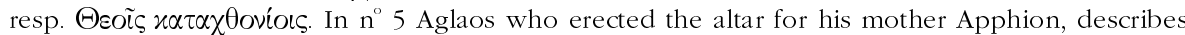
himself as hieros, a designation of an unclear status in the service of Zeus. Two texts $(6,10)$ mention fines against those who would violate the grave; $\mathrm{n}^{\circ} 6$ is of great interest, because it

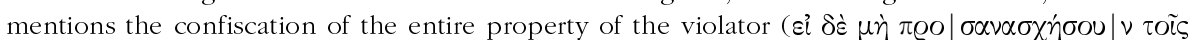

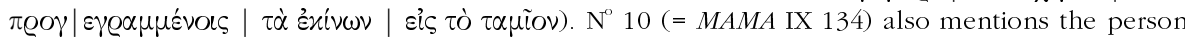
who would take care of the funerary altar. We also note a funerary imprecation (63) with the

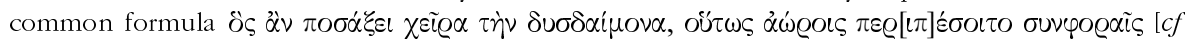
the remarks of C. BRIXHE, BE 2003, 506]. [JM]

91) G. Maddoli, "Nuovi testi da Iasos", PP 56 (2001), p. 15-32 [BE 2002, 388]: Ed. pr. of three fragments of an epidosis list which records contributions made for the organization of the Dionysia (Iasos, 2nd cent.) [for the Iasian epidosis lists for the Dionysia see I.Iasos 160-218; EBGR 1993/94, 161; 1995, 87]. The donors include agonothetai (B2-3), a stephanephoros (B2), and 
choregoi (B2-3). A decree (A, c. 200 B.C.) [SEG LI 1506] mentions the neopoiai as the magistrates responsible for inscribing an older decree on the frame of a door or a window of the archeion prostatikon (i.e., the seat of the prostatai). For the chronology see infra $\mathrm{n}^{\circ} 103$. [AC]

92) H. Maehler, "Bakchylides and the Polyzalos Inscription", ZPE 139 (2002), p. 19-21 [BE 2003, 340]: M. argues that the original dedicatory inscription of the famous bronze statue of the charioteer at Delphi commemorated a chariot victory of Hieron in 482 or 478 B.C., while he

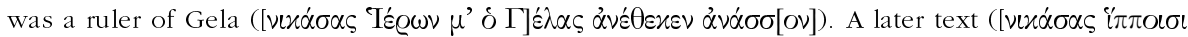
$\left.\Pi] \circ \lambda \dot{u} \zeta \alpha \lambda \circ \varsigma \mu^{\prime} \dot{\alpha} v^{\prime} \theta \eta \eta \varkappa \varepsilon v\right)$, inscribed with the approval of the Amphictyons, transferred the commemoratory inscription to Hieron's brother Polyzalos. [JM]

93) A. Maffi, "La lex sacra di Selinunte e la purificazione dell'omicida", in E. CANTARELLA - G. THÜR (eds), Symposion 1997. Vorträge zur griechischen und hellenistischen Rechtsgeschichte (Altafiumara, 8-14 September 1997), Cologne/Weimar/Vienna, 2001, p. 209-214: M. argues that the lex sacra of Selinous, which concerns purifications [SEG XLIII 630; cf. EBGR 1996, 45; 1998, 93; 2000, 28] is not an internal regulation of a sanctuary or a norm of a strictly religious character, but a city law. The text of B 1-7 refers to the purification of persons

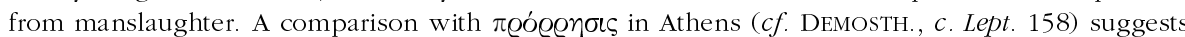
that the procedure introduced with the participle $\pi 00 \varepsilon i \pi \dot{\omega} \nu$ (B 2) refers to an announcement made by a representative of the victim's relatives, who has agreed with the exiled homicide to open the procedure of pardon and reconciliation. $[\mathrm{AC}]$

94) A. Magnelli, "Iscrizioni", in A. Di ViTa (ed.), Gortina V.3. Lo scavo del Pretorio (1989-1995). T. II. I materiali, Padova, 2001, p. 626-654 [SEG LI 1136-1140]: Ed. pr. of the inscriptions found in the so-called "Pretorio" of Gortyn (Crete), which in an early phase was a gymnasium complex. These texts include a series of honorary inscriptions for athletes, which provide new evidence for the agon of the Cretan Koinon (c. A.D. 100-150). The pankratiast Diogenes (11) was a periodonikes and winner of the pentaeteric agon of the Cretan Koinon

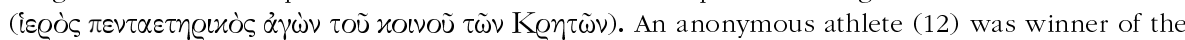
Olympia in Smyrna and possibly the Sebasta Nemea. Two further pankratiasts, winners of the periodos, remain anonymous (13-14). [AC]

95) A. Magnelli, "Un'inedita dedica a Hermes da Gortina (Creta)", in S. BianchetTI (ed.), ПOIKI $1 M A$. Studi in onore di Michele R. Cataudella in occasione del 600 compleano, La Spezia, 2001, p. 679-685 [SEG LI 1141]: Ed. pr. of an inscribed base dedicated by an agoranomos, after his term in office, to Hermes Polykarpos (Gortyn, c. 100-50 B.C.). M. discusses the perception of Hermes as the patron of the agora and of fertility. [AC]

96) I.A. MaKarov, "From the History of Religious Cults in Tauric Chersonesus", ACSS 8 (2002), p. 189-198: English version of the article summarized in $E B G R 2001,117$. [AC]

97) P. Marchetti, "En relisant les comptes de Delphes autour de l'archonte Palaios", $B C H 126$ (2002), p. 59-72: After autopsy of the stone, M. excludes the restoration $\Pi \alpha \lambda \alpha$ iou as name of the archon in a Delphic account of naopoioi (CID II 56 I A 7; 338/7 B.C.). According to M., the accounts of the treasurers CID II 77 and CID II 75 belong together and date to the very beginning of the archontate of Dion (autumn 336 B.C.). [JM]

98) C. Marek, "Die Phylen von Klaudiupolis, die Geschichte der Stadt und die Topographie Ostbithyniens", $M H 59$ (2002), p. 31-50: A new honorific inscription for Septimius Severus (Bithynion/Klaoudioupolis in Bithynia, A.D. 198), set up by the archontes of the phylai, gives the names of the city's twelve tribes. Half of them derive their names from names of gods (Apollonis, Asklepias, Demetrias, Dia, Dionysias, Hermesias), the other half are directly or indirectly related to emperors (Sebaste, Traianis, Hadrianis, Antinois, Antonine, Aureliane). Because of the mention of a gymnasiarchos (1. 15: $\gamma$ u.) M. suggests that the statue base was dedicated in the theater on the occasion of a festival. In this context M. discusses the evidence for the names of tribes in Prousias ad Hypium (Iuliane, Sebastene, Germanike, Tiberiane, Hadriane, Sabiniane, Antoniane, Faustiniane, Megaris, Thebais, Prousias, Dionysias); one observes the absence of names related to prehellenistic elements (e.g., Baradendromianoi and Petrozetoi in 
Nikomedeia). One may assume that originally all the tribes' names in Bithynion/Klaoudioupolis derived from theonyms, but some of them were later replaced by imperial names. The lack of a tribe named after Claudius is surprising; the tribe Antinois honored Antinoos, a native of Bithynion and Hadrian's lover, after his deification. A comparison of the honors awarded to Antinoos in Antinoopolis in Egypt, in Bithynion, and in Mantineia, shows that they included the same elements: temple, mystery cult, agon; a tribe in Antinoopolis had the name Oseirantinoeioi. M. briefly discusses the mythical ancestry between the Arkadians and the Bithynians. [AC]

99) G. MARginesu, " $\Lambda$ É $\chi \varepsilon$ in una iscrizione funeraria da Camiro (DGEEP 273)", AION arch. 8 (2001), p. 135-138 [SEG LI 1020]: The peculiar feature of an epitaph in Kamiros (IG XII.1, $709=$ Tit.Cam. 160, ca. 550-500 B.C.) is the designation of the monument as a $\lambda \dot{\varepsilon} \sigma \chi \eta$ and the reference to the genealogy of Euthytidas (three generations). M. argues that the term $\lambda \hat{\varepsilon}^{\prime} \chi \eta \eta$ is related to the public role of the grave monument as a meeting place of the family members, as the center of the memory of the family, which was structured around genealogies; it may also be related with the notion of afterlife as an eternal symposion. [AC]

100) G. Marginesu, "Due frammenti di iscrizioni vascolari dal santuario sull'acropoli di Gortina”, ZPE 140 (2002), p. 67-70: Ed. pr. of two graffiti on sherds from the acropolis of Gortyn (late 7th/early 6th cent. B.C.). On the first fragment M. suggests reading the name of the

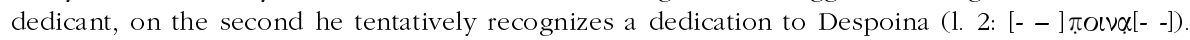
[JM]

101) Th. Marksteiner - M. WÖRrle, "Ein Altar für Kaiser Claudius auf dem Bonda tepesi zwischen Myra und Limyra", Chiron 32 (2002), p. 545-569: Ed. pr. of the dedicatory inscription on a monumental altar dedicated by the Lykian Koinon for emperor Claudius (Kaklık in Lykia, A.D. 45/6). The dedication was made in gratitude for the peace and for the construction

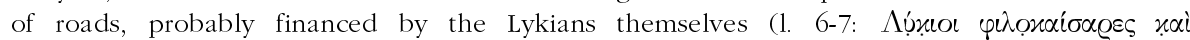

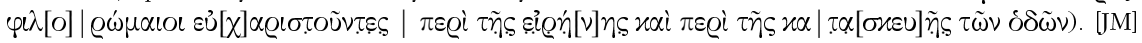

102) A. MaRTíneZ-FernÁNDEZ - V. Ninioú-Kindelí, "Inscripciones del Heroon de Aptera (Creta)", ZPE 138 (2002), p. 270-272 [BE 2003, 423]: Ed. pr. of five inscriptions found during excavations at a precinct near the principal gate of Aptera (Crete). The precinct seems to have been used as a heroon from the Classical period to the 7th cent. A.D. All inscriptions date to the 2nd cent. A.D. and attest the honorific title of $\ddot{n} \varrho \omega \subseteq$ given to private persons by the city. Only one

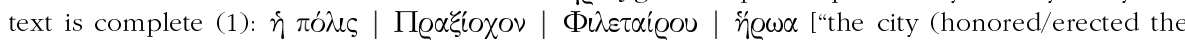
statue of) Praxiochos, the son of Philetairos, a hero"; on the cults of Aptera see also infra $\mathrm{n}^{\circ} 137$, p. 261-267]. [JM]

103) N. Maurizi, "A proposito dei nuovi testi di coregia da Iasos", PP 56 (2001), p. 4268: Discussion of the chronology of the new choregic documents presented in supra ${ }^{\circ}$ 91. [AC]

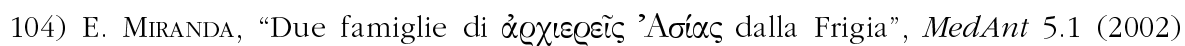
p. 39-48: M. discusses the career of two elite families of Roman origin in Phrygia, the members of which served as high priests of the emperor cult in Asia. M. Claudius Valerianus from Eumeneia and his wife Claudia Terentulla occupied the high priesthood of Asia in c. 84-96; M. Claudius Valerianus Terentullianus (MAMA IV 336; SEG XXVIII 1115-1116), high priest after c. A.D. 132, must have been their son. His nephew (?), M. Flavius Valerianus Terentullianus, who also served as high priest of Asia, was honored by P. Aebutius Flaccus, as a new inscription from Hierapolis shows. The new inscription associates the family of Eumeneia with the family of the Aebutii of Hierapolis. P. Aebutius Flaccus can be identified with Aebutius Flaccus, high priest at Kyzikos (IGR IV 153, c. A.D. 100-150). He is one of the ancestors of Aebutius Flaccus Apphianos, known as a descendant of archiereis Asias from an unpublished inscription of Hierapolis under the Tetrarchy. The priesthood of Aebutius Flaccus in Kyzikos confirms the assumption that the archiereis of Asia did not always exercized this function in their own conventus. [AC]

105) H. MülLER - M. WÖRrLe, "Ein Verein im Hinterland Pergamons zur Zeit Eumenes' II.", Chiron 32 (2002), p. 191-235 [BE 2003, 437]: Ed. pr. of an inscription (168-164 B.C.) found in 1969 in the Kaikos valley. The text on the two sides of the stone regulates ritual and 
financial issues of an unspecified association (Attalistai?). The first five fragmentary lines of the front side seem to regulate sacrificial matters ( $c f$. the term $\sigma \pi \lambda \alpha \gamma \chi \chi \nu i \tau \alpha \varsigma$ in A 3 ). The following lines (A 6-15) refer to the award of crowns to the deified King Attalos I and his wife Apollonis, living members of the royal family, high officials of Pergamon (among them the archiereus for the cult

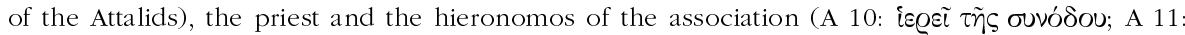
ieQovó $\mu \omega t$ ) by the archepimenioi (= hieropoioi) of the association. The rest of the text on the front side refers to financial issues. The back side is much more mutilated; one recognizes a

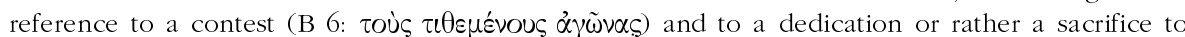

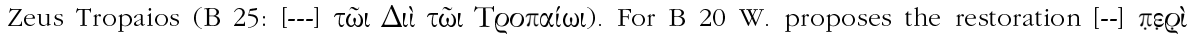

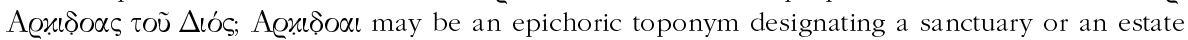
belonging to Zeus (Tropaios?) [cf. the remarks of Ph. GAuTHIER, BE 2003, 437]. [JM]

106) D. Musti, "Nuove riflessioni sui Nikephoria pergameni e Diodoro Pasparo", RFIC 127 (1999), p. 325-333 [BE 2002, 351]: M. defends his view on the trieteric character of the Nikephoria of Pergamon [cf. EBGR 1999, 32 and 169; 2000, 90] and on the historical context of the activities of Diodoros Pasparos (during the Aristonikos War) [cf. infra $\mathrm{n}^{\circ} 107$ and the remarks of Ph. GAUTHIER, BE 2002, 351]. [AC]

107) D. Musti, "Un bilancio sulla questione dei Nikephoria di Pergamo", RFIC 128 (2000), p. 257-298 [SEG XXXIX 1770]: Critical review of recent publications on the periodicity of the Nikephoria of Pergamon (trieteric according to M., pentaeteric according to C.P. JONES and others) [cf. supra $\left.\mathrm{n}^{\circ} 106\right]$. [AC]

108) M. NAFISSI, "L'iscrizione di Laodice (IvIasos 4). Revisione del testo e nuove osservazioni", PP 56 (2001), p. 101-146 [BE 2002, 390]: N. presents a substantially improved edition of the honorary decree for Queen Laodike, the wife of Antiochos III, and an excellent commentary (I.Iasos 4; Iasos, c. 196 B.C.). The most interesting aspects of the text are the modification of the rituals which accompanied the inauguration of magistrates in their office and the introduction of new rituals in honor of Laodike. N. plausibly associates the perception of king Antiochos III as "guardian" of the city with the new ritual of the delivery of the keys by the strategoi to their successors; this ritual took place near the altar for Antiochos III; after the new strategoi received the keys of the city, they performed a sacrifice to the king and to the other

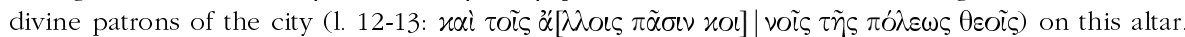
According to his restorations, a virgin was to be elected as the priestess of Laodike; she was allowed to serve only for one term. The honors for Laodike included a procession lead by the priestess on the queen's birthday (15 Aphrodision) under the participation of all the priests and priestesses, the brides and the bridegrooms, who were to offer a sacrifice to Laodike, and the virgins who were to get married in the rest of the month (?). N. suggests that the virgins made as a pre-marital offering (aparche; $c f$. proteleia gamou) a hair offering (1. 30: $\alpha \pi \alpha \varrho[\chi \xi ́ \sigma \theta \omega \sigma \alpha \nu \alpha u ̉ \tau \tilde{\eta} !$ $\tau \tilde{\eta} \varsigma$ xóunc]). [AC]

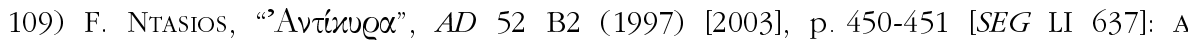

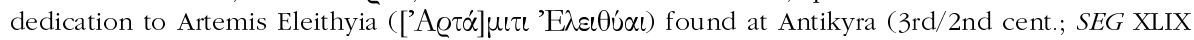
567 ) was already presented in $E B G R 2000,135$. N. provides information on the site, where the inscription was found, and presents an improved text. N. points out that PaUSANIAS (X 37,1) mentions a sanctuary of Artemis located on the peninsula of Kephale; two inscriptions (IG IX.1, 5 and an unpublished one) mention priestesses of Artemis Diktynnaia. [AC]

110) J.P. Oleson - M.B. ReEves - B.J. FISCher, "New Dedicatory Inscriptions from Humayma (Ancient Hawara), Jordan”, ZPE 140 (2002), p. 103-121: Ed. pr. of three dedications found in the Nabataean settlement of Hawara in the Hisma of Southern Jordan; they are probably connected with the Roman garrison at Hawara. The monuments are an altar dedicated to Zeus Megistos Kapitolios (1, 2nd-3rd cent.), a statue base dedicated to an unknown divinity (2, 2nd cent. A.D.), and a column dedicated to Zeus Sarapis in expression of gratitude

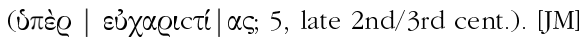


111) G. PACI, "La grande stele delle sacerdotesse di Era dall'agorà di Cirene", Quaderni di Archeologia della Libya 16 (2002), p. 271-284: New critical edition of the list of the priestesses of Hera (Kyrene, 1st/2nd cent.; SEG IX 182) and discussion of its chronology. [AC]

112) D. Pandermalis, "New Discoveries at Dion", in M. Stamatopoulou - M. YeroulaNOU (eds), Excavating Classical Culture. Recent Archaeological Discoveries in Greece (BAR Int.Series 1031), Oxford, 2002, p. 99-107: P. discusses briefly a dedication on the abacus of a Doric capital (Dion, 170-168 B.C.) [SEG XLIX 697; EBGR 1999, 179]. The cult association of the Mousaistai dedicated to the Muses and Dionysos a statue in honor of king Perseus for his benefactions towards the association and for his piety towards the gods (1. 5-6: x $x i$

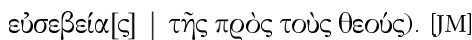

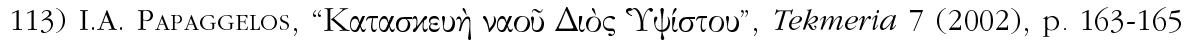
Ed. pr. of an inscription which records the construction and dedication of a temple of Zeus

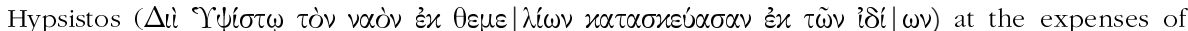
Zoilos and his wife Kratisto, citizens of Antiocheia (Thessalonike?, 2nd-3rd cent. A.D.). [JM]

114) R. PARKer, "A New Euphemism for Death in a Manumission Inscription from Chaironeia", ZPE 139 (2002), p. 66-68 [BE 2003, 331]: P. shows that the obligation of manumitted slaves in a manumission record from Chaironeia (P. ROESCH - J. M. FossEY, "Neuf actes d'affranchissement de Chéronée", ZPE 29 [1978], p. 129-131, n 6, late 3rd/early 2nd cent.) is not connected with honours for a goddess, but with the fulfillment of funerary and other

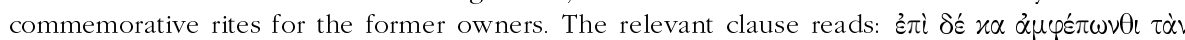

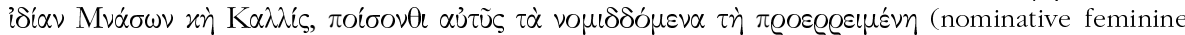

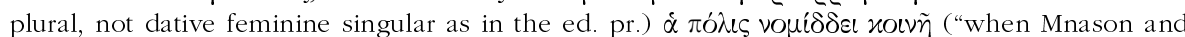
Kallis die, the aforementioned women will together perform for them [not for an unnamed goddess] the customary rites which are the custom of the city"). [JM]

115) A. PASQUier, Revue du Louvre 50.2 (2000), p. 90 (ph.): P. briefly presents an important new acquisition of the Louvre. It is the upper part of a bronze pedimental stele; the middle of the pediment is decorated with a relief bust of Hadrian (Naryx, A.D. 138). The stele contains a letter of Hadrian, with which the emperor allays the fear of the Narykeans that one might doubt their right to the status of a ró $\lambda \iota c$. [P. does not present the text, which can be read on the photo (see

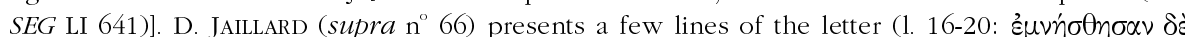

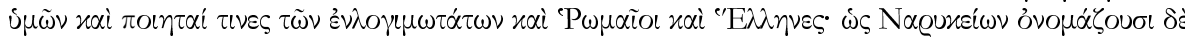

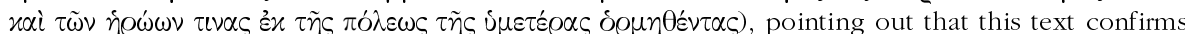
the reading $\dot{\alpha} \pi \dot{\mathrm{O}} \mathrm{N} \dot{\alpha}<\mathrm{Q}\rangle>\varkappa O \zeta$ in Calumachus, Aetia fr. 35. The text alludes to the Lokrian Aias (cf.

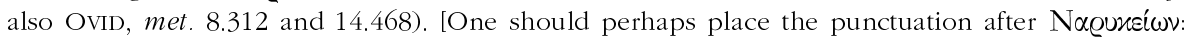
"and some of the most famous poets, both Romans and Greeks, have mentioned you as Narykeians; and they explicitly name some of the heroes as originating in your city". As evidence for the polis status of Naryx the emperor, who certainly summarizes the arguments of the envoys of Naryx, mentions inter alia the participation of Naryx in the Delphic Amphictyony (1. 10-11: eic

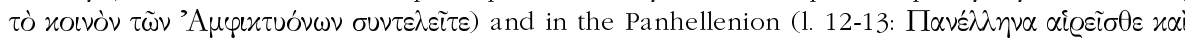

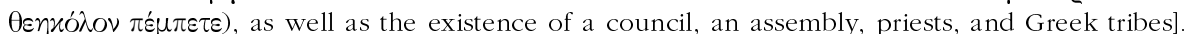
$[\mathrm{AC}]$

116) J.-L. Perpillou, "Animaux d'un an", $R P h 76$ (2002), p. 233-241: The adjective

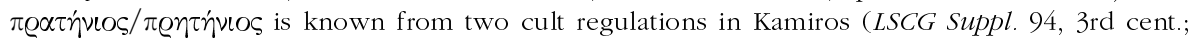

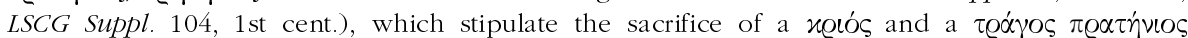

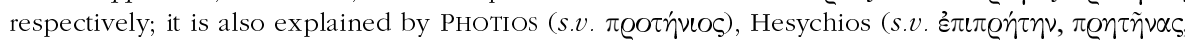
$\pi \varrho x \tau \dot{v} v(O v)$, and Eustathios (1625.35, $\pi \varrho \eta \tau \tilde{\eta} \nu \varepsilon c)$. It refers to yearling animals, the sacrifice of which is often mentioned in leges sacrae. P. discusses the etymology of the word (from $*_{h_{1}}$ en- $=$ year). [Cf. ID., RPh 75 (2001), 152]. [AC]

117) U. Peschlow - A. Peschlow-Bindokat - M. WÖRrle, "Die Sammlung Turan Beler in Kumbaba bei Sile (II). Antike und byzantinische Denkmäler von der bithynischen Schwarzmeerküste", MDAI(I) 52 (2002), p. 429-522: Ed. pr. of inscribed objects in the 
collection of Turan Beler in Kumbaba (Bithynian Chersonesos). The most interesting text is a funerary altar (117, late Imperial period) inscribed on all four sides and set up by Sosios for himself and his wife Eia on the estate where his funerary monument ( $\tilde{h} \omega \dot{\omega} v \varepsilon \iota 0 v)$ was built. The text on side B is a funerary foundation delimitating an estate for the person who would perform the rites of the grave cult for Sosios and Eia $(\delta \pi \alpha \rho \alpha \varkappa \alpha(i) \omega \nu$, i.e., the person who would perfom the rites of parentalia and rosalia, which were introduced to Bithynia under Roman influence); the text ends with a greeting to those who would address the grave with respect ( $\chi \alpha i ́ \varrho \varepsilon \tau \varepsilon$ oi

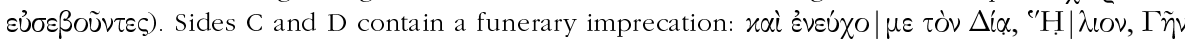

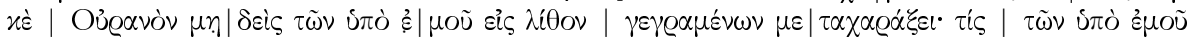

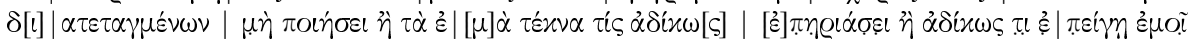

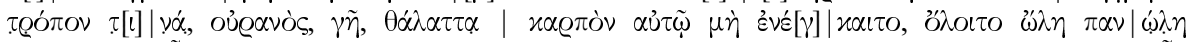

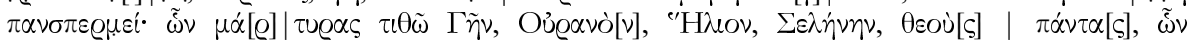

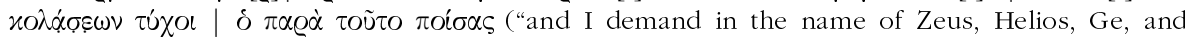
Ouranos that nobody changes what I have writenn on this stone. If somebody does not fulfill my arrangements or harasses unfairly my children or in any way undertakes something unfair against me, then neither the sky nor the earth nor the sea shall bear him any fruits, and he both he and his descendants shall perish. For this my witnesses are Ge, Ouranos, Helios, and Selene and all the gods; whoever acts agaist this will be subject to their punishment"). A small altar was dedicated by Talaris to Bendis upon divine command (122, Imperial period: T $\alpha \lambda \alpha \alpha_{\varrho} \varsigma \Delta \alpha---\mid \varepsilon O \varsigma$

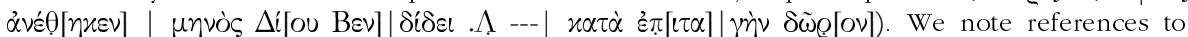
months: Areios (117), Dios (122), and Heraios (130). [JM]

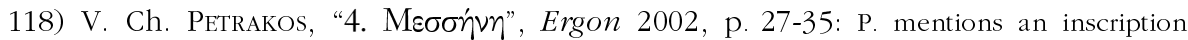
found near the doric temple next to the fountain of Arsinoe during the excavations of P. THEMELIs at Messene. The text reads $\Delta i \Sigma \omega \tau \tilde{\eta} \varrho$ and permits a possible identification of the divinity honored in the temple with Zeus Soter. [The cult of Zeus Soter was already attested in Messene (IG V 1, 1440, 1st cent. A.D.). PAusanias (IV, 31, 6) refers only to a statue of Zeus Soter near the fountain of Arsinoe at the agora of the city]. [JM]

119) G. PETZL, "Neue Inschriften aus Lydien (IV). Kulturbeflissenes Nordostlydien", EA 34 (2002), p. 94-102 [BE 2003, 464]: Ed. pr. of a very interesting epitaph from northeast Lydia (3, A.D. 226). Living and deceaced members of the family of Diogenes and Secunda honor them posthumously with the erection of a stele; deceased members of the family ( $x \dot{\varepsilon}$ of $\pi \varrho 0 \mid \alpha \dot{\xi} \alpha \nu \tau \varepsilon \varsigma$

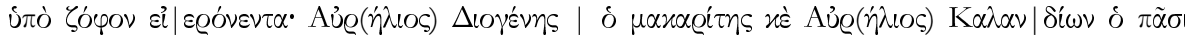
$\varphi(\lambda) \subseteq)$ are included among the honorands probably because they had contributed to the erection of the funerary monument; the deceased couple is described as "joined with the bonds (of

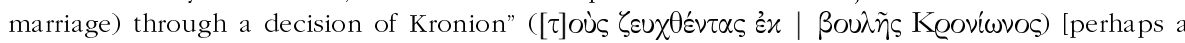
reference to an oracle of Zeus which recommended this marriage]. [AC]

120) P. Pilhofer, Philippi. Band I. Die erste christliche Gemeinde Europas, Tübingen, 1995: The first volume of an important synthesis dedicated to the history of Philippi in the first two centuries A.D. places the Christian textual evidence (especially the letters of Paul and Polykarpos and the History of the Apostles) against the background of the inscriptions. Ample use of the epigraphic evidence is made for the study of the cults in the early Imperial period

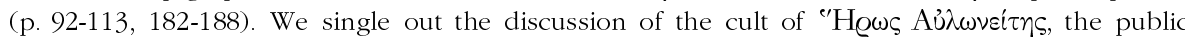
character of the cult and its procuratores (p. 93-100), the worship of Dionysos (p. 100-107) and Silvanus (p. 108-112), and the character of the cult of Theos Hypsistos as a local cult and not the result of Jewish influence (p. 182-188), the Jewish community (p. 231-234), and the first Christians (p. 240-245) [cf. supra $\mathrm{n}^{\circ} 13$ and infra $\mathrm{n}^{\text {os }} 121-122$ and 148]. [AC]

121) P. Pilhofer, Philippi. II. Katalog der Inschriften von Philippi, Tübingen, 2000 [SEG L 604, 617]: In the second volume of his work, P. presents a corpus of the published inscriptions of Philippi and its territory [but also of neighboring areas, which have never been part of the territory of Philippi; see the critical remarks of M. B. Hatzopoulos, BE 2001, 304, M. SEvE, An.Ép. 2000 [2003], n ${ }^{\circ} 1323$, J. BARTELS, BZ 95 (2002), 710-711, and SEG L 617]. The inscriptions attest inter alia the cult of Thea Almopia (602) [cf. SEG L 618], Apollon (191, 359), Apollon 
Komaios, (246), Artemis (246), Artemis Opitais (18), Botrys Dionysos (535), Dionysos (499, 501, 501a/b, 501d), Dionysos [---]oios (417), Heros (623, 626, 626a), Heros Epekoos (618), Heros Aulonites (580, 619, 624/625; cf. 622: Theos Heros Auloneites), Theos Hypogaios (92), Meter Theon (468), Nemesis Aneiketos (142-144), Pan (545), Plouton (527), Poseidon (509a, kyrios), Zeus (568b), the Egyptian gods (12, 190), and the ruler cult of Philip V (568). The Archaic and Classical inscriptions found in Kavala (ancient Neapolis; 1-20, 22-24, 26-30) include a dedication to Parthenos $(6,5 \mathrm{th} / 4$ th cent.) and sherds of vases found in the sanctuary of Parthenos (7-16, 6th4 th cent.). An undated seal (17) names the same goddess (17). We single out only very few interesting texts. Funerary cult: Several inscriptions mention the performance of the rites of rosalia and parentalia, under Roman influence. A woman bequeathed 150 denarii to the

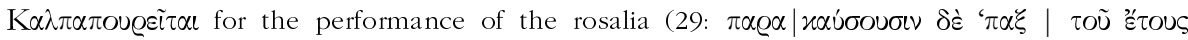
ఏódoเs; 2nd cent. A.D.; $c f$. 597). Another woman fulfilled the will of her husband and gave money

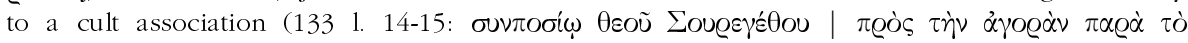

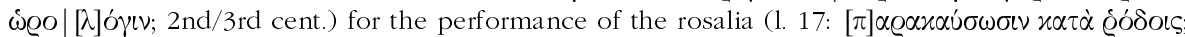

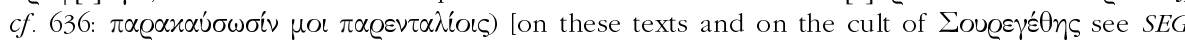

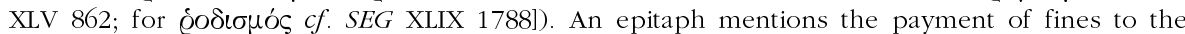
Jewish synagogue (387 A) [for this text $c f$. SEG XVLIII 837]. Dedications: A vewxó@oৎ̣ dedicated a

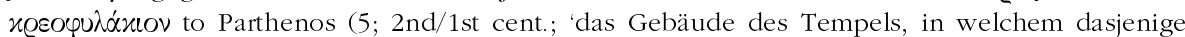
Fleisch der Opfer aufbewahrt wird, welches zur Ernährung der Priester ausgesondert war'). Cult

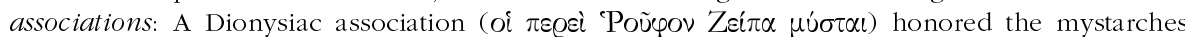

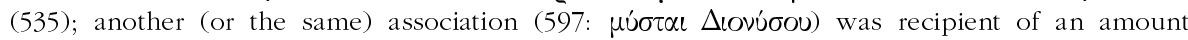
bequeathed by a man. $[\mathrm{AC}]$

122) M.-D. Poncin, "Les prêtrises publiques dans la colonie de Philippes", CGG 12 (2001), p. 229-252: P. studies the public priesthoods in the Roman colony of Philippi (pontifex, flamines, sacerdos Divae Augustae, seviri Augustales, priests of the imperial cult, augures), on the basis of the Latin inscriptions of the city. [AC]

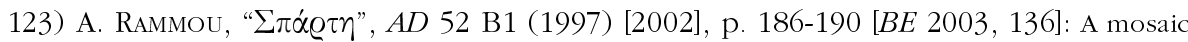
discovered in a bath in Sparta is decorated with representations of crowns and inscriptions which record victories at the following agons: Didymia [in Miletos], Olympia, Eurykleia [in Sparta, $c f$. SEG XXXVI 1090], Kaisareia, Kornelia, Pythia, and Isthmia (late 3rd/early 4th cent.). [AC]

124) Chr. Riedweg, "Poésie orphique et rituel initiatique. Éléments d'un « Discours sacré » dans les lamelles d'or", RHR 219.4 (2002), p. 459-481: The texts on the 'Orphic' lamellae show a mixture of metrical lines and rhythmical prose; e.g., in the text from Pelinna (SEG XXXVII 497) three phrases in rythmical prose (1. 3-5) appear between the dactylic verses in lines 1-2 and 6-7. This change in form correlates to a change in content, the dactylic verses containing a narrative section, the prosaic phrases commemorating a ritual performance (during the initiation or the funeral). Based on this observation, which applies in a different measure to all the texts - except for the text of the group C from Timpone Grande [see supra $\mathrm{n}^{\circ} 8$ ] -, R. argues that the prosaic text are an adaptation of the poetical narrative, serving as a kind of a libretto for the performance of the rituals during the initiation. He plausibly reconstructs the sequence of the texts in the original poem (hieros logos), in which a person (Orpheus?) gave instructions to the initiates for their journey to the underworld: death and the katabasis of the soul, description of the topography in the palace of Hades, meeting with Persephone and other gods, exchange of oral symbola, allusion to the condition of the Blessed, final exhortation of the initiate. [We did not have access to two new corpora of the 'Orphic' texts: A. Bernabé - A.I. JIMÉNEZ SAN CRISTOBÁL, Instrucciones para el más allá. Las laminillas órficas de oro, Madrid, 2001; G. Pugliese CARratelli, Le lamine d'oro orfiche. Istruzioni per il viaggio oltremondano degli iniziati greci, Milano, 2001; see also W. BURKERT, "Die neuen orphischen Texte: Fragmente, Varianten, 'Sitz im Leben'”, in W. Burkert - L. Gentilli Marciano - E. Matelli - L. Orelli (eds), Fragmentsammlungen philosophischer Texte der Antike, Göttingen, 1998]. [AC]

125) K.J. RigsBy, "A Greek Inscription from Troia, 2001", Studia Troica 12 (2002), p. 275-277: Ed. pr. of a fragmentary decree of Antiocheia (= Alabanda in Karia) found in Ilion, 
with which judges from Ilion are honoured (Ilion, 3rd cent.). According to R.'s plausible restoration, the text mentions the agon of the Dionysia and the sanctuary of Apollon (Isotimos) in Antiocheia/Alabanda. [JM]

126) T. RitTI, "Un decreto onorario di Hierapolis per Tiberius Iulius Myndios", Mediterraneo Antico 4 (2001), p. 489-555 [SEG LI 1783]: Ed. pr. of a very interesting honorary decree for the local benefactor Tib. Iulius Myndios, who made a foundation in order to promote the cult of Zeus in Hierapolis (c. A.D. 117-138). Myndios, who served as an envoy to Hadrian in A.D. 117, is known from a (possibly earlier) dedicatory inscription from the theater of Hierapolis (SEG XLI 1200), of which R. presents (p. 495) an improved, but still preliminary text. Together with his wife Glykonis, priestess of the Dodekatheon, Myndios dedicated to Zeus Olympios, the Theoi Patrioi, the emperor Hadrian, the imperial family, and the Demos a

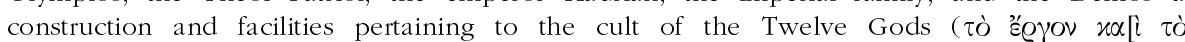

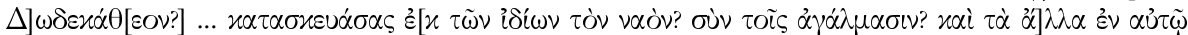

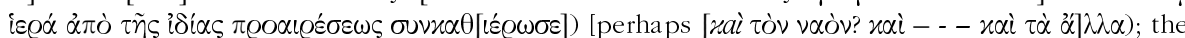
Dodekatheon mentioned after the égyov possibly is not a cult building, but a group of statues of the Twelve Gods in the theater]. The interest of Myndios for the cult of Zeus may be related to the promotion of this cult under Hadrian, who in A.D. 128 was awarded the title Olympios. The agon of the Olympia in Hierapolis may be related to the promotion of Zeus Olympios under Hadrian (p. 533). The new inscription, of which R. presents a thorough commentary, honors

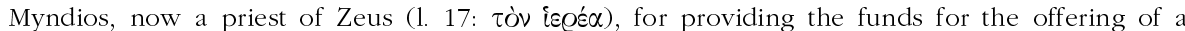
sacrifice to Zeus (1. 1-14). The sacrifice was to be offered by Myndios together with 30 councillors

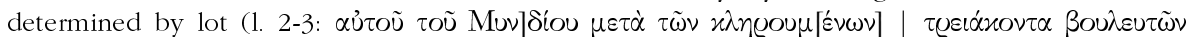

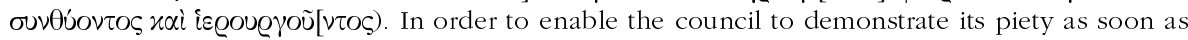

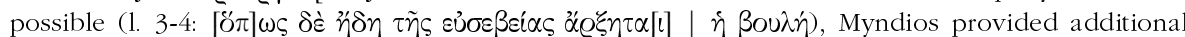
funds. His benefaction may have been part of summa honoraria for the priesthood (p. 504). The honorary decree is followed by a lex sacra concerning [the reorganization of] the rituals in the cult of Zeus: "The priest Tiberius Iulius Myndios will begin/officiate the sacrificial ceremonies during the offering of annual libations and sacrifices to Zeus: on the 14th day of the second month at the set of the Pleiads; on the 18th day of the eighth month during the offering of the new roses; on the day of the Sebastos (= on the first day) of the tenth month, a ritual bath in honor of Zeus; on the second of the Sebastos (i.e., the second day of the month), sacrifices of the festival Dia; and on the 18th day of every month, in accordance with the acts and the decrees of

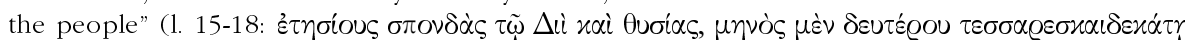

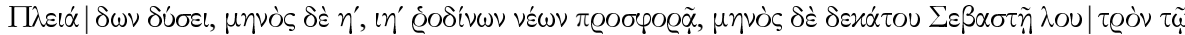

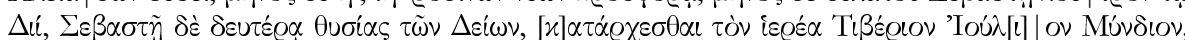

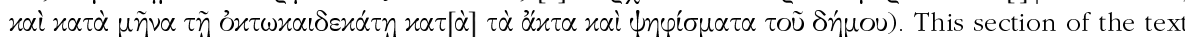
is a sacrificial calendar concerning the cult of Zeus. The first sacrifice was offered at the set of the Pleiads (late October/early November), which marks the beginning of the seasonal agricultural activities; Zeus was probably perceived as patron of these activities. The offering of a crown of roses took place in the spring (18 Daisios, c. May 11). The ritual bath on the first day of Loos (c. June 24) should not be understood as the washing of Zeus' statue, since such a ritual washing is attested only for statues of goddesses [see now T.S. SCHEER, Die Gottheit und ibr Bild, Munich, 2000 , p. 57-60], but as a ritual bath, possibly a purificatory bath either of the priest or of worshippers, in honor of Zeus. The annual festival of Zeus was celebrated on the next day. It is not clear why sacrifices were offered on the 18th day of each month ( $c f$. the offering of roses 18th day of the eighth month); they probably commemorated an important event; R.'s plausible explanation is that Hadrian had visited Hierapolis on the 18th day of a month (June or July 18th, A.D. 129 [but Hierapolis did not use the Roman calendar; it must be the 18th day of a local summer month, e.g. 18 Panemos (c. June 11) or 18 Loos (c. July 11)]. [AC]

127) T. RiтTi, "Documenti epigrafici dalla regione di Hierapolis", EA 34 (2002), p. 41-70 [BE 2003, 131 and 510]: Ed. pr. of an inscription on a sarcophagus [in second use?] at Motalla

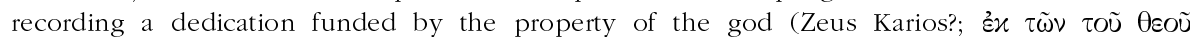
$\chi \varrho \eta \mu \alpha \dot{\tau} \tau \nu)$. In a discussion of the inscriptions of localities in the vicinity of Hierapolis, $\mathrm{R}$. comments on already published inscriptions which include two stelae erected by the Thiounteis 
in honor of phratries which funded a pannychis in honor of Zeus for 8 days (W.M. RAMSAY, The Cities and Bishoprics of Phrygia, Oxford, 1897, I nos 30-31, Thiounta), a stele erected in honor of a priest of Zeus, represented in a libation scene under Zeus' bust (SEG XXXI 1127, Thiounta), and dedications to Theoi Motaleon (SEG XXXIII 1138 and XXXIV 1298, Motalla). [AC]

128) H.S. RoberTs, "Pots for the Living, Pots for the Dead. Were Pots Purpose-made for the Funeral or Reused? Can Inscriptions Throw Light on the Problem?", in A. RathjeM. Nielsen - B.B. Rasmussen (eds), Pots for the Living, Pots for the Dead (Acta Hyperborea 9), Copenhagen, 2002, p. 9-31: The epigraphic evidence (e.g., CID I 9; cf. LSCG 97 1. 810) and archaeological finds suggest that pots used for the funeral or as grave goods were sometimes brought from the house and sometimes purchased. In the case of initiates in the Dionysiac-Orphic mysteries, R. detects connections between the grave goods and the religious beliefs of the buried initiates: e.g., the pottery found in the grave of an 'Orphic' in Pelinna (SEG XXXVII 497) includes a statuette of a maenad; a woman buried at Lokroi was grasping in her hand a vase shaped as a maenad, which possibly marked her as an initiate of Bacchic mysteries; such maenad-vases are also found in Olbia, where the presence of 'Orphics' is attested (IGDOP 94); the 'Orphic' lamella of Pharsalos (SEG XXIII 410), which refers to the water of Mnemosyne, was found inside a hydria; the two skyphoi and the lamp found outside the Hipponion tomb (SEG XXVI 1139) may be connected with a final rite of libation, a jug and hydriae may be allusions to the lakes of the Underworld. [AC]

129) A. Rostad, "Confession or Reconciliation? The Narrative Structure of the Lydian and Phrygian 'Confession Inscriptions", SO 77 (2002), p. 145-164: After a study of the narrative structure of the 'confession' inscriptions and their vocabulary [cf. EBGR 1994/95, 285], which emphasizes the appeasement of divine wrath, rather than the confession of sin and the admittance of guilt, $R$. plausibly argues that the explanation of the divine punishment and the reconciliation are the central aspects of these texts, which, therefore, should be characterized as "reconciliation inscriptions" [ $c f$. already EBGR 1994/95, 68: "propitiatory inscriptions"; see now also the study of A. CHANIOTIS, "Under the Watchful Eyes of the Gods: Aspects of Divine Justice in Hellenistic and Roman Asia Minor", in S. Colvin (ed.), The Greco-Roman East. Politics, Culture, Society (YCS 31), Cambridge, 2004, p. 1-43]. R. points out that the resolving of oaths and curses are crucial element in these texts and concludes: "the basic elements of the reconciliation would be sacrifices, ritual cleanings and dedications of inscriptions, not confession" (p. 162). [This conclusion is somewhat exaggerated: the public confession was also part of the reconciliation ritual. R. has not taken into consideration some of the recent scholarship on the subject: e.g. EBGR 1994/95, 68 and 305; 1997, 72; 1998, 207-208; 1999, 148; 2000, 187; some of the translations are not accurate; ė $\pi ! \zeta \eta \varepsilon \dot{\omega} \omega$ in these text does not mean "investigate" (p. 153), but "pursue a case";

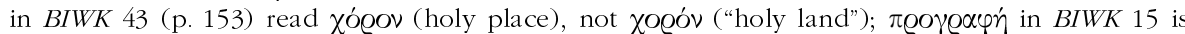

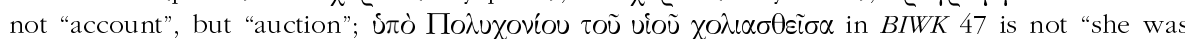

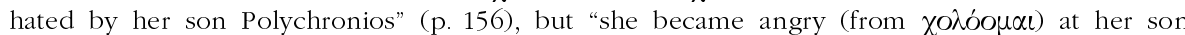

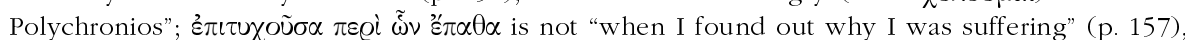
but "when I was healed from my suffering (literally, "when I had success in my wish with regard

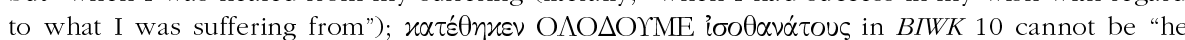

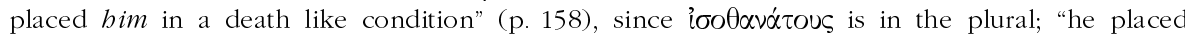

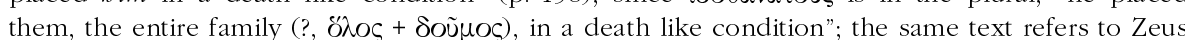
Didymeites (not "Didymeitos")]. [AC]

130) G. Rougemont, "Delphes hellénistiques et l'oracle", in R. Frei-Stolba - K. GeX (eds), Recherches récentes sur le monde bellénistique. Actes du colloque organisé à l'occasion du 60 anniversaire de Pierre Ducrey, Lausanne, 20-21 novembre 1998, Bern, 2001, p. 65-74 [SEG LI 599]: Critically reviewing the current views on the decline of the Delphic oracle in the Hellenistic period, R. points out that these views are influenced by the fact that the oracle was not consulted by Hellenistic kings and by the nature of the sources. A close study of the literary and epigraphic evidence shows that the oracle was consulted by communities for religious matters (foundation of cults and festivals, recognition of the asylia of cities and sanctuaries), for diplomatic contacts, and for military matters; the oracle also continued to be 
consulted by private persons. A decline can be observed in the late Hellenistic period, which should be regarded as a distinct historical period - not only for Delphi. [AC]

131) M.C. ŚAHIN, "New Inscriptions from Lagina, Stratonikeia, and Panamara", EA 34 (2002), p. 1-21 [BE 2003, 483]: Ed. pr. of 48 inscriptions from Lagina (1-34), Stratonikeia (3547), and Panamara (48). Lagina: The most interesting text is a fragmentary lex sacra (1, c. 350-300 B.C.) which concerns the cult of "the daimon of Leros" (1. 6: Sxínovọ $\Lambda$ śow; cf. LSAM 56); the text seems to be the final section of an honorary decree [of the demos or of an association?] for Leros and another person (his wife?), who are called "benefactors" (1. 2-4: ó $\sigma i \omega \varsigma, x \alpha[i[\varepsilon \dot{\sigma} \sigma \varepsilon \beta \tilde{\omega} \varsigma$,

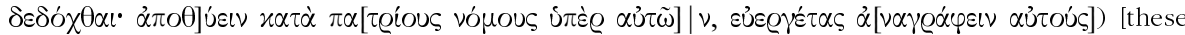
restorations, suggested ex.gr. by S. are unlikely; $\dot{\alpha} \pi \circ \theta \dot{v} \omega$ is rare, and one would expect $x \alpha \tau \dot{\alpha} \tau o \dot{y} \varsigma$

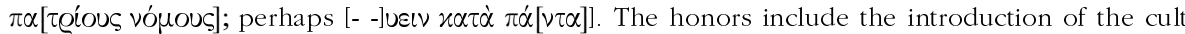

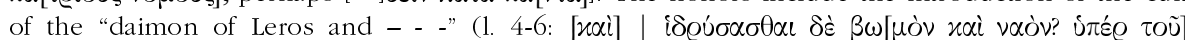

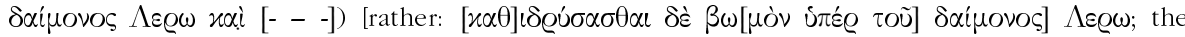
erection of a temple is very improbable]. The best preserved part of the text (1. 6-14) concerns a

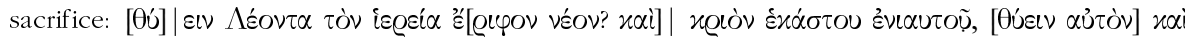

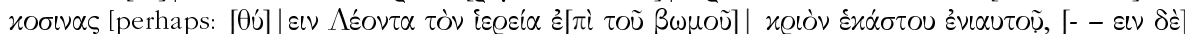

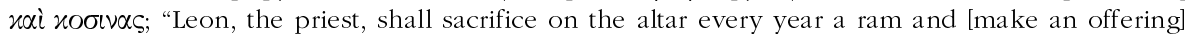

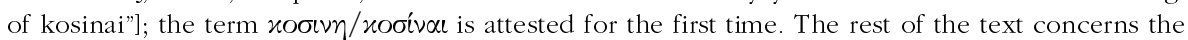

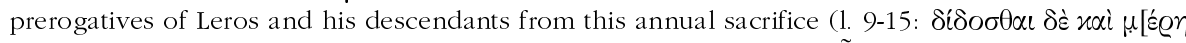

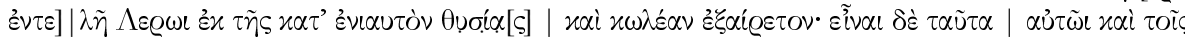

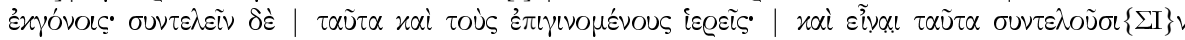

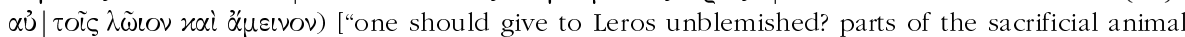
from the annual sacrifice as well as a thigh; these privileges should be valid for him and his descendants; the future priests should fulfill this, and if they do so, let them flourish"]. The other texts from Lagina record the dedication of the statue of woman by her brothers to Hekate (3, c. 50 B.C.); the dedication of an altar at the expenses of the priest Demetrios (iręùs

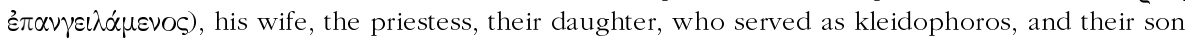
(5, Imperial period); the dedication of hair by a man (6, late Imperial period) [for this phenomenon see M. GIRONE, "Una particolare offerta di chiome", EA 35 (2003), p. 21-42]; the dedication of a statue to the gods (33, Imperial period); honors for kleidophoroi ( 7 and 13 , Imperial period); honors for a priest (?) (10) [who took care of the suppliants in the sanctuary; in 1. 7-8 one may

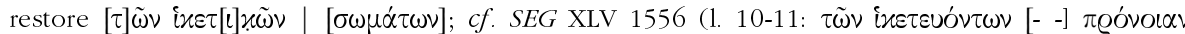

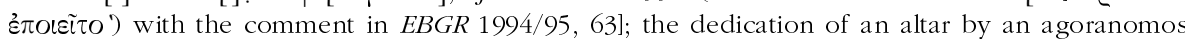
(8, Imperial period); the offering of wine and olive oil by priests and couples of priests on

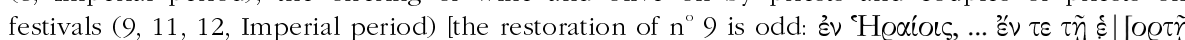

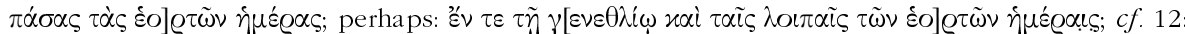

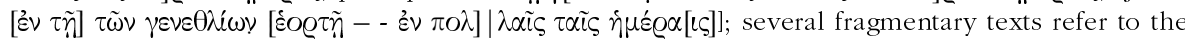
services of priests or couples of priests (17-28); one recognizes references to the worshippers

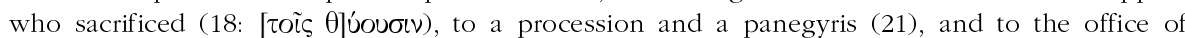

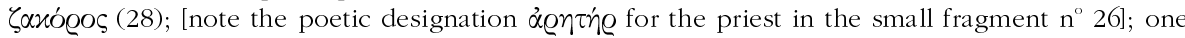
of the best preserved texts commemorates the services of the priest Chrysaor (14; $c f$. I.Stratonikeia 22.1, 690), who served as priest of Zeus Panamaros, Zeus Chrysaorios, and another

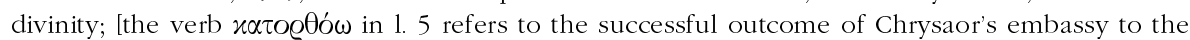

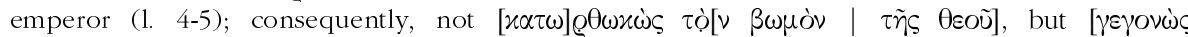

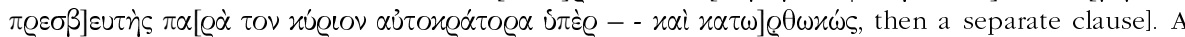
small fragment mentions a Didymeion (the sanctuary of Apollon and Artemis at Lagina?, 31). Stratonikeia: An inscription honors Menelaos, who served as high prist of the (city) emperor cult

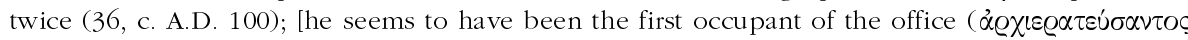

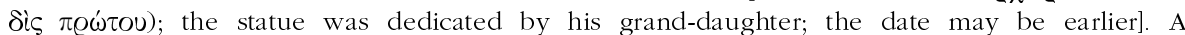
dedication is addressed to Zeus Panemeros (37, a vow). An altar decorated with a crescent was set up for Theion Polymorphon (38, late Imperial period); this is a new epithet for Theion; the cult of Zeus Hypsistos and Theion with many epithets is attested in Stratonikeia and its territory; S. associates them with Isis and Sarapis. Two other altars were destined for the cult of Eirene (40)

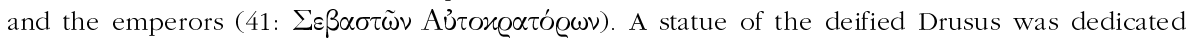




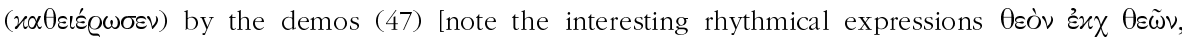

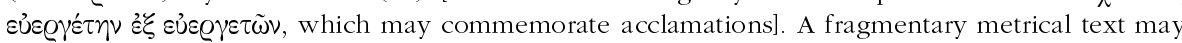
be an oracle (39); [one recognizes references to Zeus (1. 1: Koovíwvi) and Athena (1. 3: [- - ]eı

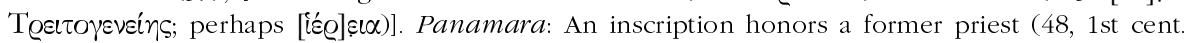
A.D.). [Cf. the remarks of C. BRIXHE, BE 2003, 483]. [AC]

132) F. Salviat, "Les Nyktophylaxia, l'enfermement de la truie et les Thesmophories de Délos d'après ID 440+456", in J.-P.BRun - P. Jockey (eds), TÉxvat. Techniques et sociétés en Méditerranée. Hommage à Marie-Claire Amouretti, Paris, 2001, p. 735-747 [SEG LI 997]: S. rejects the interpretation of the ritual of the Delian ritual of the Nyktophylaxia as a festival of the dead (as suggested by A. SCHACHTER; EBGR 1999, 219) and presents conclusive arguments for linking this ritual with the Thesmophoria and with the promotion of fertility. According to the information provided by the accounts of the hieropoioi (IG XI 145 1. 30; I.Délos $440-456=S E G$ XLVIII 1039), the Nyktophylaxia were a night celebration, during which a pregnant sow was thrown alive into a subterranean megaron (cf. I.Délos 199 1. 148) in the Thesmophorion, which may be identified with the building GD 123. This ritual took place in the month Aresion (November); the remains of the sow were collected by women (cf. the antletriai in Athens) in

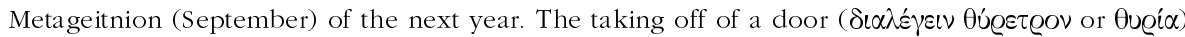
and the building of a wall (Evomodousiv) mentioned in the accounts in connection with the Nyktophylaxia (I.Délos 154 1. 25-26; 199 1. 48-49; 372 1. 93-94; 442 1. 193) refer to the opening and closing of the megaron, when the sow was thrown into it and when her remains were removed. During this ceremony the female celebrants kept guard in the Thesmophorion (I.Délos 142:

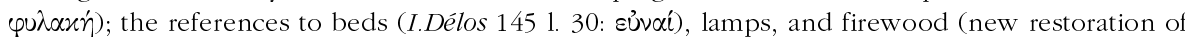
I.Délos 440+456) are connected with this ceremonial guard. [S. rightly observes (p. 742) the military connotation of the terms $\varphi \cup \lambda \alpha x \dot{\eta} / \mathrm{N} \cup x \tau O \varphi \operatorname{u} \lambda \dot{\alpha} \xi \ldots$. It should be noted that the Athenian

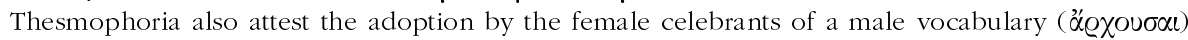
and the occupation of the male domain (the Pnyx); see H. S. Versnel, Inconsistencies in Greek and Roman Religion 2, Leiden, 1994, p. 240 note 40 and p. 251 note 80]. [AC]

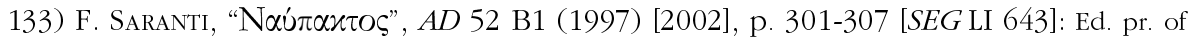
a mosaic inscription on the floor of a late antique building near the Hellenistic wall (Naupaktos,

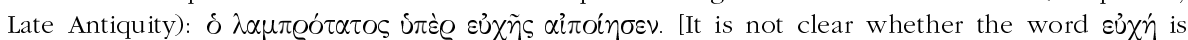
used in the pagan ("vow") or the Christian sense ("prayer")]. [AC]

134) K. Seaman, "Athletes and Agora-phobia? Commemorative Athletic Sculpture in Classical Athens", Nikephoros 15 (2002), p. 99-115: S. suggests that the statue of Leagros, son of Glaukon, in the Athenian Agora ( $I G \mathrm{I}^{3}$ 951) was dedicated by himself to the Twelve Gods after 480 B.C. and stood near their altar at least until the end of the 4th cent. B.C. [JM]

135) A. SIDERIS, "Bronze Drinking Vases Bearing Dedicatory Inscriptions", Eirene 38 (2002), p. 167-201: Ed. pr. of two bronze kylikes and a bronze skyphos dedicated to Zeus $\mathrm{Na}$ (i)os and found in the sanctuary of Zeus at Dodona (late 4th cent.); the dedicatory inscriptions

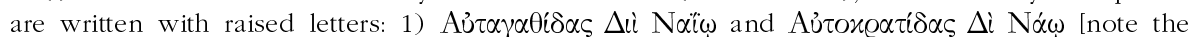

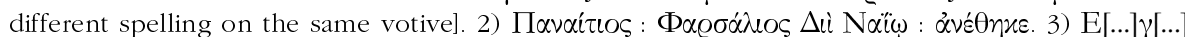
$\dot{\alpha} \nu[\varepsilon] \theta[\eta x \varepsilon] \Delta[i]] \mathrm{N}[\alpha \dot{i} \omega: \delta] \tilde{\omega} \varrho O v$. Ed. pr. of bronze kantharos with raised letters, dedicated to Kore, found in the vicinity of Gortyn in Arkadia (early 3rd cent.): Kó@ $\alpha$. [JM]

136) M. Stavova, "Mystery Clubs in Bulgarian Lands in Antiquity. Greek Epigraphical Evidence", OAth 27 (2002), p. 137-149: Based on 17 inscriptions S. studies mystery cult associations in Bulgaria (Augusta Trajana, Apollonia Pontica, Cillae, Dionysopolis, Gradiste, Montana, Nikopolis ad Istrum); except for one, these testimonia refer to Dionysiac mystery cults.

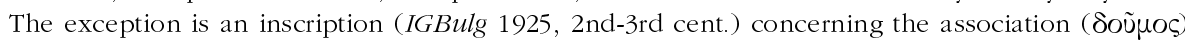
of female worshippers of Kybele and naming one of the functionaries (1. 3: $\mu \dot{\eta} i \eta \varrho ~ \delta \varepsilon v \delta \varrho o \varphi o ́ \varrho \omega v)$. The Dionysiac mystery associations are designated as $\sigma \pi \varepsilon i g \alpha$ (IGBulg 23, 480, 671, 1517, 1518; SEG XXXIX 649), $\beta a \varkappa \chi(\varepsilon)$ iov, a term which also describes the place where Dionysiac gatherings took place (IGBulg 1864, 1865, 5579), or Kotvóv (IGBulg 671). Beside the typical names, such as

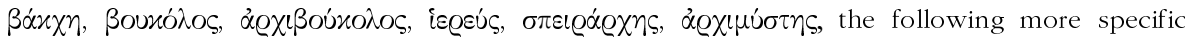


names for worshippers and functionaries are attested in the Dionysiac mystery associations

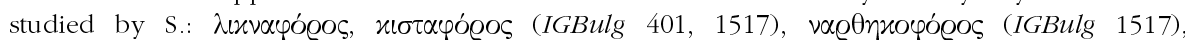

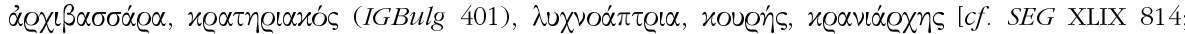

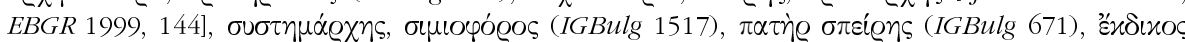

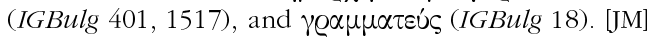

137) J.D. Sosin, "Two Attic Endowments", ZPE 138 (2002), p. 123-128: 1) D. suggests a new restoration of an Athenian document which deals with financial aspects of the sacrifices of

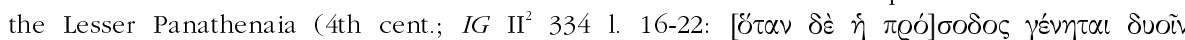

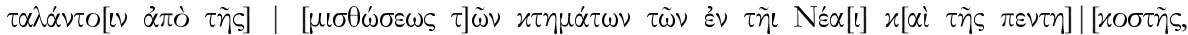

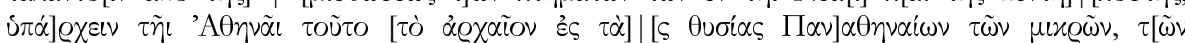

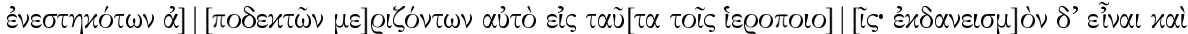

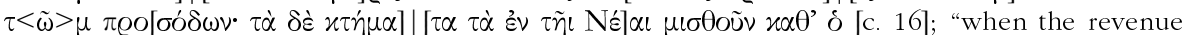
from the lease of the properties in the Nea and the pentêkostê reach two talents, this sum shall belong to Athena for the sacrifices in the Lesser Panathenaia, the apodektai in office disbursing it to the bieropoioi for his purpose. These shall be a lending also of the revenue. The land in the Nea shall be leased according to what ..."). 2) D. proposes a restoration of a document which describes the settlement of a dispute concerning the property of a private cult association (3rd

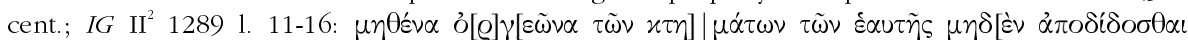

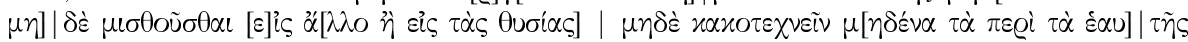

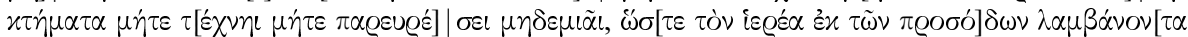

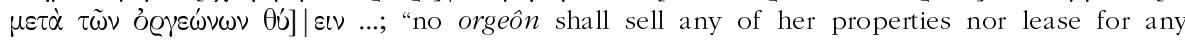
purpose other than for the sacrifices, nor do evil to anything pertaining to her properties, neither by craft nor on any pretext, so that the priest, taking from the revenues, may sacrifice with the orgeônes ..."). [JM]

137bis) K. SpORn, Heiligtümer und Kulte Kretas in klassischer und hellenistischer Zeit (Studien zu antiken Heiligtümern, 3), Heidelberg, 2002: S. studies the archaeological, epigraphic, numismatic, and literary evidence for sanctuaries in Classical and Hellenistic Crete [but without a discussion of festivals]. S. provides an invaluable insight into the Cretan pantheon during the aforementioned periods. In the first and lengthiest part of this study the cults in every Cretan city are surveyed, while the second part is a systematic analysis of the material presented in the catalogue. [JM]

138) E. Stavrianopoulou, "Die Familienexedra von Eudamos und Lydiadas in Megalopolis", Tekmeria 7 (2002), p. 117-156: Ed. pr. of three blocks belonging to an exedra and bearing honorary inscriptions (190-180 B.C.) for Eudamos and his son Lydiadas, the last tyrant of Megalopolis. The decree for Eudamos (A1) documents the honors posthumously awarded by the city of Megalopolis: A bronze statue should be erected in an unknown temenos; S. cautiously suggests identifying it with the temenos for an already heroized member of the

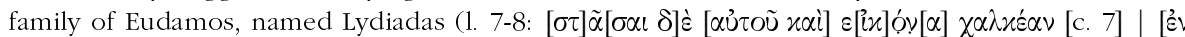

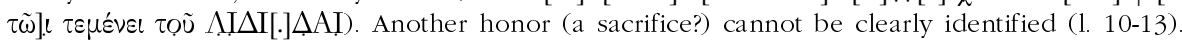
An annual sacrifice of a sheep was to be performed on the altar of Eudamos; the sacrifice should

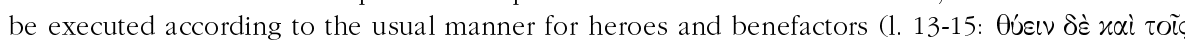

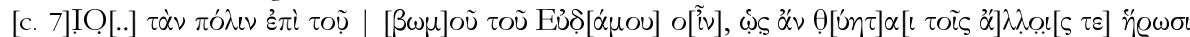

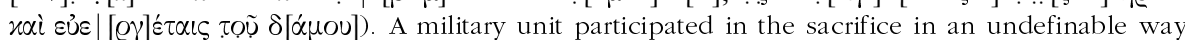

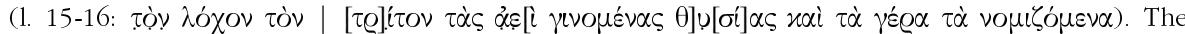

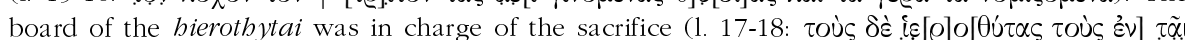

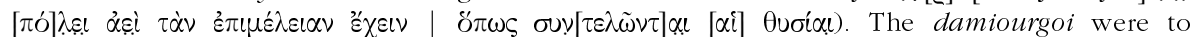
announce the honors for Eudamos to all Greeks during the festival of the Eleutheria at Plataiai (1.

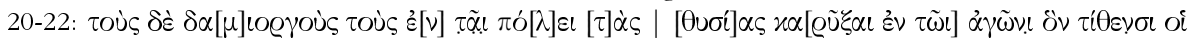

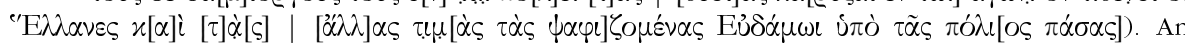
inscription recording these honors was to be erected by the city near the bronze statue of

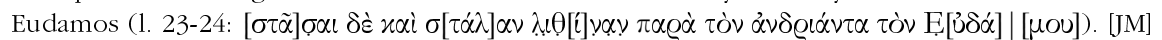


139) Chr. Steimle, "Neue Erkenntnisse zum Heiligtum der Ägyptischen Götter in Thessaloniki. Ein unveröffentlichtes Tagebuch des Archäologen Hans von Schoenebeck", AEMTh 16 (2002), p. 291-306: A round altar bearing a dedicatory inscription (IG X.2.1, 84,35 B.C.) was reused as a statue base in the 2 nd cent. A.D., bearing a dedicatory inscription to

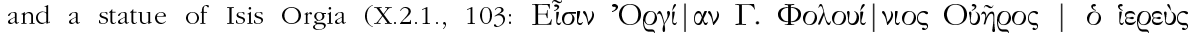

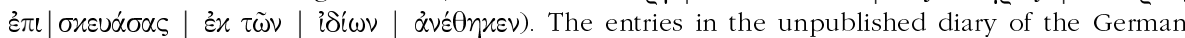
archaeologist H. VON SCHOENEBECK show that this dedication stood in the cella of the the socalled "apsis-temple" in the sanctuary of the Egyptian gods in Thessaloniki. [JM]

140) J.-Y. STRASSER, "Quelques termes rares du vocabulaire agonistique", $R P h 75$ (2001), p. 273-305 [SEG LI 585, 604, 608, 973, 1102 bis; BE 2003, 187]: In an important contribution to the vocabulary of agonistic inscriptions $S$. interprets in a new way several designations of

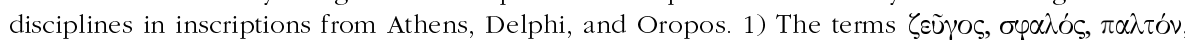
and $\pi \tilde{\alpha} \lambda$ oc appear in a list of victors at the Eleusinia (c. 150 B.C.) in the context of equestrian

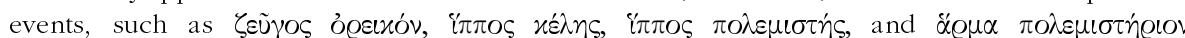
(J. KIRCHNER - S. DOW, "Inschriften vom attischen Lande", MDAI(A) 62, 1937, p. 3-5 n 2; W. PEEK, "Attische Inschriften", $M D A I(A) 67$ [1942], p. 164). S. demonstrates that these terms also designate equestrian competitions reserved to Athenians: $\pi \alpha \lambda \tau$ óv probably refers to throwing a javelin while

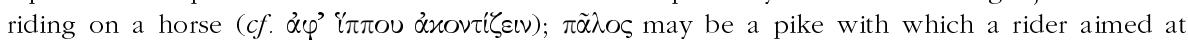
hitting a target; he restores this term in an inscription of Olbia (IOSPE $\left.\mathrm{I}^{2} 157\right)$; $\sigma \varphi \tilde{\alpha} \lambda O \varsigma$ is "un

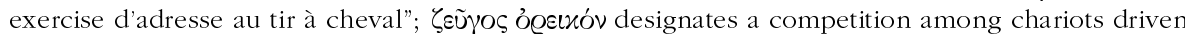
by a pair of mules. In a agonistic dedication recording victories at the Eleusinia and the Theseia

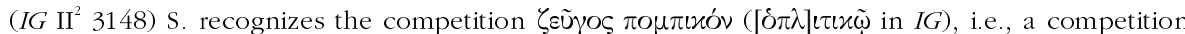
among processional chariots, which is also attested for the Panathenaia $\left(I G \mathrm{II}^{2} 2311 \mathrm{~B} 65\right)$ and

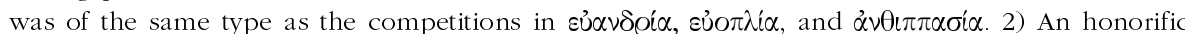
inscription in Delphi (F.Delphes III.1, 534, c. A.D. 50) records the athletic victories of three virgins.

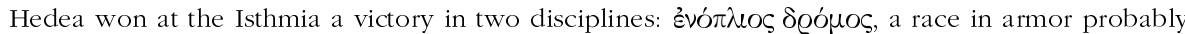

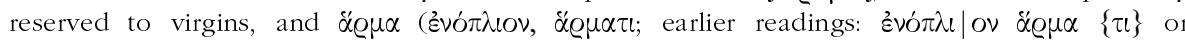

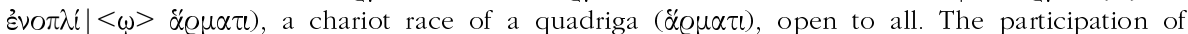
women in races is attested in the Imperial period [cf. F. FERRANDINI TrOISI, La donna nella società ellenistica. Testimonianze epigrafiche, Bari, 2000, $\mathrm{n}^{\circ}$ 6.3], but this would be the only attestation of a race of virgins in armor (in honor of Athena?); races in armor among men are well attested

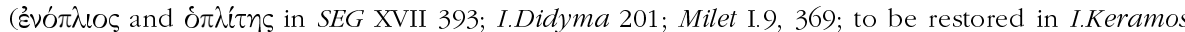
15). The discipline Ėvó $\pi \lambda$ เov $\check{\alpha} \mu \alpha$, interpreted as a race of war chariots or war horses ("i $\pi \pi 0 \varsigma$

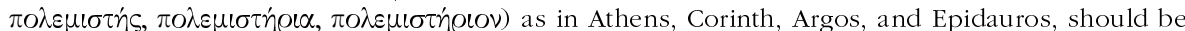
deleted from the agonistic vocabulary. 3) The term $\pi \rho \delta \alpha \alpha \sigma \iota c$ mentioned in the honorific

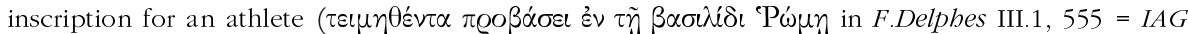
87 , mid-3rd cent. A.D.) is usually interpreted as a synonym of $\pi \rho 0 \pi 0 \mu \pi \varepsilon i \alpha$, i.e., the privilege of leading a procession; S. rejects this interpretation, not only in view of the existence of the term $\pi 00 \pi о u \pi \varepsilon i x$, but also because leading the procession was the privilege of the high priest of the association of athletes; the usage of the verb $\pi \varrho \circ \beta \alpha i v \omega$ ( $c f$. progredior) suggests a different interpretation: 'notre champion s'est vu octroyer le privilège de se distinguer au milieu de ses collèges pour accomplir un geste quelconque lors des concours, ou pour parler devant l'assemblée réunie à cette occasion, athlètes, éventuellement artistes, spectateurs' (299). S. associates with this honor, probably a distinction during a parade, the representation of a parade of a victorious athlete in a mosaic at Baten Zammour in Tunisia (M. KHANOussi, "Spectaculum pugilum et gymnasium", CRAI 1988, p. 543-561; early 4th cent. A.D.). 4) Two lists of victors at the Amphia-

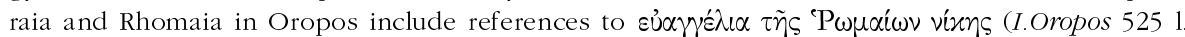
68-69 and 529 1. 22-23). L. RoberT (Laodicée du Lycos, Québec/Paris, 1969, p. 273-274) regarded it as a competition, A. SCHAChTER (Cults of Boiotia. 3. Potnia to Zeus, London, 1994, p. 26-27) as an

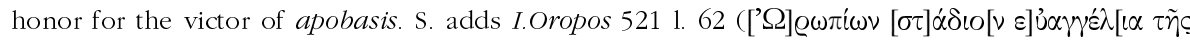

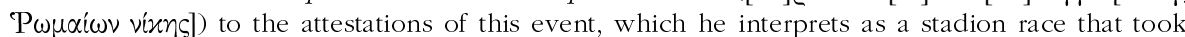
place to celebrate the good tidings of the Roman victory; this contest was reserved for the Oropians. In this context (p. 301 note 188) he also suggests that the Eretrian races $\Lambda$ euxiou

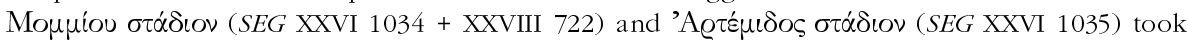


place during the same festival (the Artemisia?) to honor Lucius Mummius and Artemis respectively, and not during two separate festivals as assumed by D. KNOEPFLER ("L. Mummius Achaicus et les cites du golfe euboïque : à propos d'une nouvelle inscription d'Érétrie”, $M H 48$ [1991], p. 253 257). [AC]

141) J.-Y. STrasser, "Deux autels de Messine rendus à Aigéai de Cilicie", EA 34 (2002), p. 149-159 [BE 2003, 549]: Two altars dedicated one to Asklepios and Hygieia Soteres Poliouchoi (SEG XIII 870), the other to these gods and to the emperor Antoninus Pius (IG XIV 402) have been attributed to Messene in Sicily ( $c f$. SEG XLVI 1264). S. argues for their attribution to Aigeai in Kilikia, pointing to the importance of the cult of Asklepios and Hygieia in Aigeai (to which L. ROBERT had attributed $I G$ XIV 402) and to the strong presence of altars with double dedications to divinities and the emperors in this city. [AC]

142) J.-Y. STRAsser, "Choraules et pythaules d'époque impériale. À propos de trois inscriptions de Delphes", BCH 126 (2002), p. 97-142: In the light of some 2nd and 3rd cent. A.D. Delphic inscriptions in honor of victors in aulos competitions in the 2 nd and 3 rd cent. A.D. (CIG 1719; FD III.1, 547 and 550; FD III.4, 478; FD III.6, 143; SEG XLII 465) S. shows that victorious choraulai in stephanitai agons are attested epigraphically only from the late 1st/early 2nd cent. A.D. onwards. This evidence seems to suggest that the initiative of introducing choraulic competitions in the great stephanitai agons came from the western part of the Roman Empire, perhaps under Domitian. In an appendix S. suggests that the cult personnel of Olympia (IvO 58-141) was elected shortly after the end of one celebration of the festival, remained in charge for the next four years, and organised the next agon. In a second appendix S. identifies $I G$ XIV 2499 (= IGR 21, Nimes) as a decree of the universal synodos of the Dionysiac artists (reign of Hadrian?). [JM]

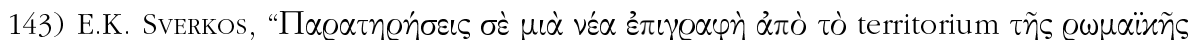

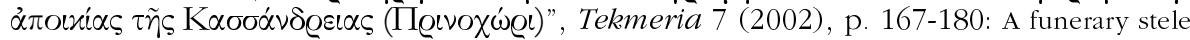
depicting the bust of the deceased in relief ( $S E G$ XLVI 746, territory of Kassandreia, c. A.D. 225250) documents the erection of the monument by Auphatios Theoros in honor of his father Louteios, son of Epaphrodeitos. Louteios must have been a member of a collegium of augustales, involved in the cult of the emperor, since this collegium contributed 75 denars for his funeral (1.

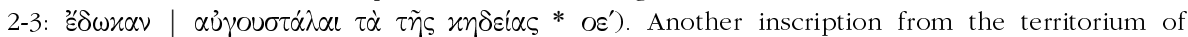
Kassandreia attests the contribution of exactly the same amount by the augustales for the funeral of a deceased member (SEG XXIX 614, Mende, Imperial Period). [JM]

144) P. Themelis, "Contribution to the Topography of the Sanctuary at Brauron", in B. GENTILI - F. PERusino (eds), Le orse di Brauron. Un rituale di iniziazione femminile nel santuario di Artemide, Pisa, 2002, p. 103-116 [BE 2003, 98]: In a study primarily dedicated to the topography of the sanctuary of Artemis in Brauron, T. presents for the first time the entire text of an important inscription concerning restorations in the Artemision [no translation or commentary of 1. 8-25], with brief discussion of the officials (1. 8-9: nomothetai; 1. 9-10: tamiai; 1. 12-13: epistatai; 1. 15: architekton bo epi ta hiera)]. Lines 2-6 are of great significance for the topography of the Artemision. In some cases, the correlations between buildings mentioned in the inscription and buildings excavated by J. PAPADIMITRIOU differ from those suggested by F. Bubenheimer and J. MylOnOPOUlos in their study of this text [see EBGR 1996, 194]. T. accepts

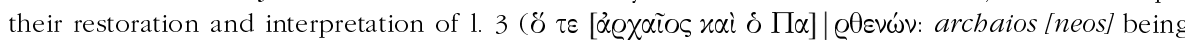
the cella and Parthenon the adyton of the temple) [see also G. EKROTH, "Inventing Iphigeneia? On Euripides and the Cultic Construction of Brauron", Kernos 16 (2003), p. 108-110]. [JM]

145) P. Themelis, "Messene, Recent Discoveries (Sculpture)", in M. Stamatopoulou M. Yeroulanou (eds), Excavating Classical Culture. Recent Archaeological Discoveries in Greece (BAR Int.Ser. 1031), Oxford, 2002, p. 229-243: T. briefly discusses the building inscription found at the entrance of room III in the west stoa of the gymnasion of Messene (late 1st cent. A.D.) [cf. $E B G R$ 1996, 255; 1997, 368]. The text documents the financing and dedication of a tempel to Hermes, Herakles and the city of Messene by Herakleidas and his son L. Peticius

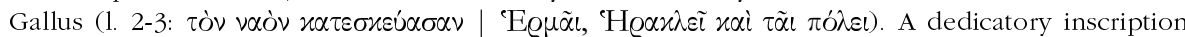


on a limestone herm representing Herakles from the area of the gymnasion attests to the cult of

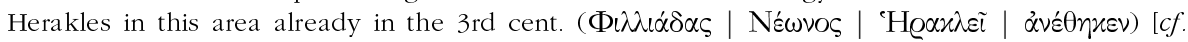
EBGR 1992, 168; 1997, 158]. [JM]

146) G. Thériault, "Remarques sur le culte des magistrats romains en Orient", Cabiers des Etudes Anciennes 37 (2001), p. 85-95 [SEG LI 2351]: T. places the cultic honors awarded to Roman magistrates in the context of divine honors for benefactors ( $c f$. his forthcoming book Bienfaiteurs grecs et romains, et les honneurs cultuels dans la cité grecque). The first Roman who was awarded such honors was not the proconsul M. Marcellus in Syracuse, since the Marcellia were not established for him, but for C. Claudius Marcellus (79 B.C.; cf. CIC., Verr. 2.51), but T. Flamininus in Gytheion (SEG XI 923), Argos (MigeOTTE, Emprunt n ${ }^{\circ}$ 20), and Chalkis (PluT., Flam. 16.5-7); other Roman magistrates who were awarded cultic honors by Greek cities include L. Mummius (SEG XXVI 1034 + XXVIII 722), Manius Aquilius (IGR IV 292 1. 38-40) M. Annius (Syll. 700 1. 36-40), Q. Mucius Scaevola (OGIS 437-439), Sulla (IG $\mathrm{II}^{2} 1039$ 1. 57; SEG XIII 279), Lucullus (PLuT., Luc. 23, 2; APP., Mithr. 76), Pompey (IG IX IX $^{2} 719$ 1. 8; IG XII.2, 59 1. 18; I.Délos 1641, 1797; G.E. BEAN, The Inscriptions of Side, Ankara 1965, $\mathrm{n}^{\circ}$ 101), Caesar (IG XII.2, 25-26; IG XII.5, 557; IG XII Suppl. 25-26; IGR IV 2728; Syll. ${ }^{3}$ 760; Iscr. COS ED 269; A.E. RAUBITSCHEK, JRS 44 [1954], p. 66 n I), P. Servilius Vatia Isauricus (I.Ephesos 702), L. Munatius Plancus (I.Mylasa 135), M. Iunius Silanus (IG XII.9, 916), and L. Sextus Appuleius (I.Alexandreia Troas 13). T. correctly stresses the extraordinary character of this honor, which expressed the gratitude of Greek communities for extraordinary services. This phenomenon declined when the emperor cult monopolized the divine honors for mortals ( $c f$. CAssius DiO LVI, 25, 6). The last testimonia concern the cults of C. Vibius Postumus (IG XII.6.1, 365; 6-9 or 12-15 A.D.), the procurator Geminus (IG V.2, 435; 1st cent. A.D.?), and Cn. Vergilius Capito (SEG XXXIV 1186 A; I.Didyma 278). $[\mathrm{AC}]$

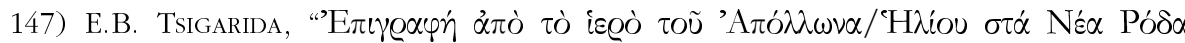

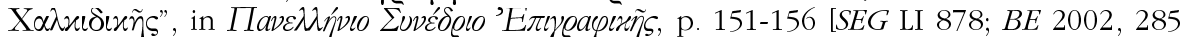
2003, 376]: T. presents an improved edition of an inscription from Sane (Chalkidike, c. 450-400 B.C.; $c f$. SEG XLVII 947) [EBGR 1998, 272], which she interprets as a boundary stone of a sanctuary. $[\mathrm{AC}]$

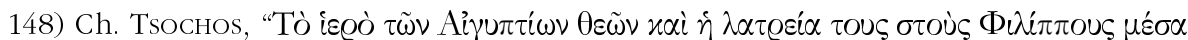

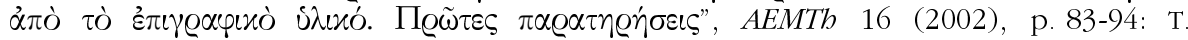
summarizes the known Greek and Latin inscriptions concerning the cult of the Egyptian deities in Philippi (2nd-3rd cent. A.D.). Based on the observation that the persons mentioned in this epigraphic material belonged to the elite of Philippi, T. suggests that this cult ranked among the most important ones in the city. [One should, however, note that the number of the preserved inscriptions is very small for such general conclusions; for the cults at Philippi see also supra $\mathrm{n}^{\mathrm{os}}$ 120-121]. [JM]

149) P. Trebilco, "The Christian and Jewish Eumeneia Formula", MedAnt 5.1 (2002),

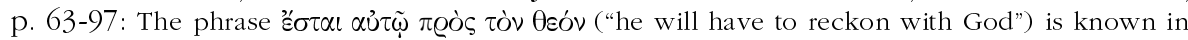
several variants from funerary monuments of Phrygia (3rd-4th cent.), where it was used in funerary imprecations. As the formula does not make clear which deity is invoked, there is a controversy about whether it was used by Christians or Jews. T.'s cautious survey of this material demonstrates that variants of the Eumeneia formula were used by Christians and Jews, but also

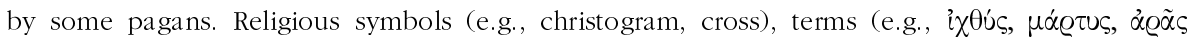

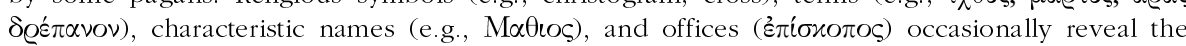
religious context, but in many cases the religious beliefs of the formula's users are impossible to determine. T. concludes that the "Eumeneia formula", which was originally created by Christians or by Jews, was shared by both religious groups; this is indirect evidence for the close relations between the two communities and the hazy boundaries between some Christians and some Jews. [T.'s plausible conclusion about the hazy boundaries between religious groups in the late Imperial period should, however, be expanded to include some pagan groups. For the religious ambiguities and the interdependence among religious groups see supra $\mathrm{n}^{\circ} 21$ and the remarks in 
earlier issues of the EBGR in Kernos 13 (2000), p. 128; 14 (2001), p. $147 f$.; 15 (2002), p. 334; 16 (2003), p. 250; 17 (2004), p. 190]. We give a list of attestations of the "Eumeneia formula" and its

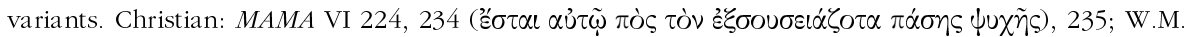

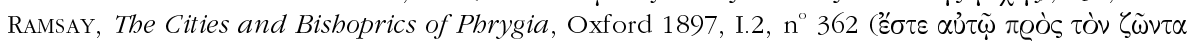

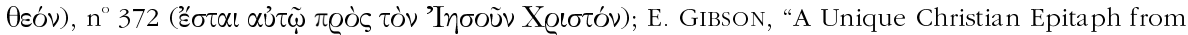

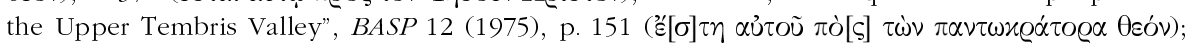
W. TABBERNEE, Montanist Inscriptions and Testimonia, Macon, 1997, $\mathrm{n}^{\circ}$ 35. Jewish?: CII 769

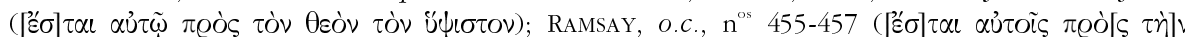

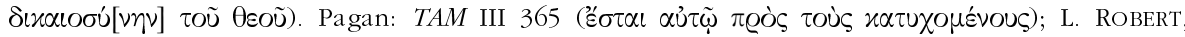

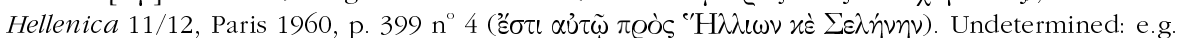
CIJ 773; LW 703 (for 'ழı

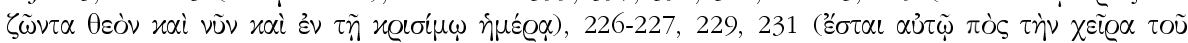

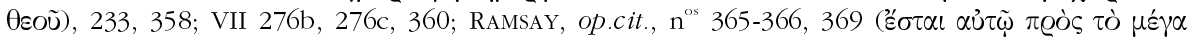

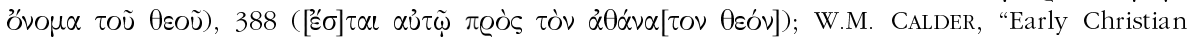

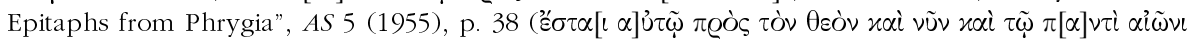

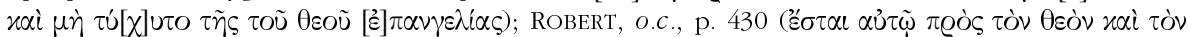

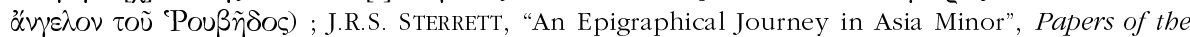

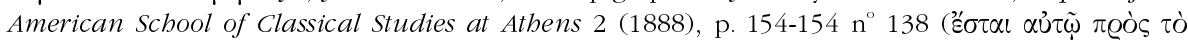

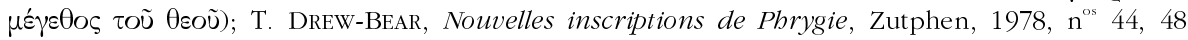

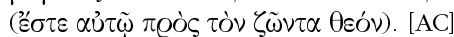

150) A. Tziafalias, "Nouòc $\Lambda$ xQín€ৎ", AD 52 B2 (1997) [2003], p. 522-526 [SEG LI 674678, 713, 721, 730]: Ed. pr. of inscriptions found in various Thessalian cities. Atrax: A

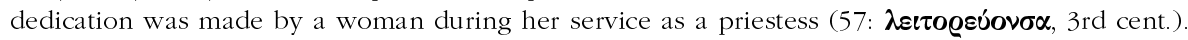
Another dedication is addressed to Artemis $(54,2$ nd cent.). The addressee of a third dedication

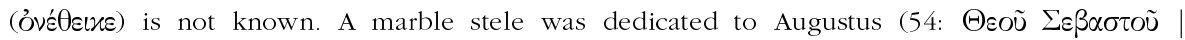

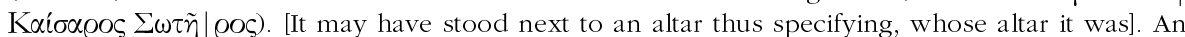
epitaph is placed under the protection of Hermes Chthonios (45, 3rd cent.). Gonnoi (?, area of): A dedication found at Makrychori ( $7 \mathrm{~km}$ south of Gonnoi) was made in fulfillment of a vow (16:

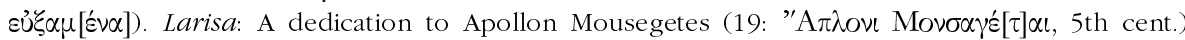
and an epitaph dedicated to Hermes Chthonios (1, 4th cent.). Phalanna: A stele dedicated to

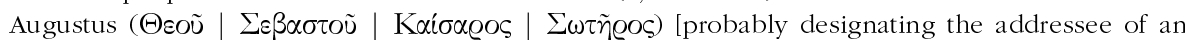
altar; cf. supra]. [AC]

151) G. Umholtz, "Architraval Arrogance? Dedicatory Inscriptions in Greek Architecture of the Classical Period", Hesperia 71 (2002), p. 261-293 [BE 2003, 89]: After a discussion of various dedicatory inscriptions in Greek architecture in a chronological order (e.g., SEG XXXI 841, temple of Apollon in Syracuse, c. 580 B.C.; I.Ephesos 1518, temple of Artemis, before 547 B.C.; Syll. ${ }^{3}$ 8, Knidian treasury in Delphi, mid-6th cent. B.C.; Syll. ${ }^{3} 29$, stoa of the Athenians in Delphi, c. 480-450 B.C.; Labraunda III.2, 13-19, Hekatomnid dedications in the sanctuary of Zeus, c. 350-300 B.C.) U. suggests that architraval inscriptions of the Late Classical Period commemorating the dedication of buildings by individuals belong to a long votive and epigraphical tradition which already begins in the 6th cent. B.C.; they cannot be regarded as the result of serious social or religious changes in this period. [JM]

152) J.G. VINOGRADOv, "Heilkundige Elearen in den Schwarzmeergründungen", in M. DrEHER (ed.), Bürgersinn und staatliche Macht in Antike und Gegenwart. Festschrift für Wolfgang Schuller zum 65. Geburtstag, Konstanz, 2000, p. 133-147 [SEG LI 938, 943, 969, 976]: V. collects epigraphic evidence which indirectly supports his view that the Orphic movement in the area of the Black Sea (SEG XXVIII 659-661; L 699) has its origin in Magna Graecia, from where it was introduced with the active participation of physicians of the Eleatic school. The most important text is a new epitaph in Olbia for a man from Elea with the characteristic name Oulios (c. 450-425 B.C.). As V. points out, the name Oulios, which is connected with the cult of Apollon Oulios [cf. EBGR 1988, 111], was used in Elea by the leaders ( $\varphi \hat{\prime} \dot{\lambda} \alpha \varrho \times O !$ ) of the association ( $\varphi \omega \lambda \varepsilon \delta$ c) founded by Parmenides [ $c f$. SEG XXX 798; XXXVIII 1020; XXXIX 1078; XLVIII 1302]. Consequently, this Oulios may have been a physician, member of Parmenides' 
school, who left Elea during the tyranny. V. recognizes a second Eleatic physician in a very fragmentary honorary decree from Kallatis (SEG XXIV $1028=$ I.Kallatis 8, c. 250-200 B.C.). Here,

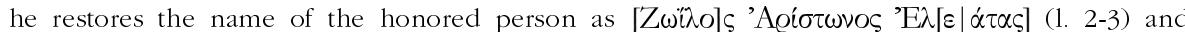

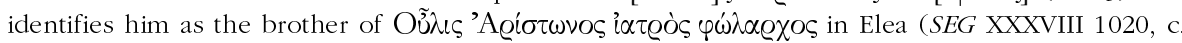
260-250 B.C.). V. speculates on the possibility that the honorand had been active as a doctor in Histria as well, where he introduced the cult of Apollon Pholeuterios (I.Histriae 105). In this context, V. interprets two marble stones found in the sacred zone of Histria (I.Histriae 105:

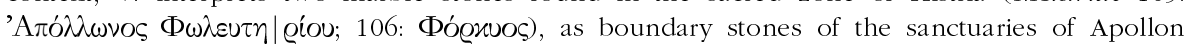
Pholeuterios and Phorkys, a maritime daemon. [AC]

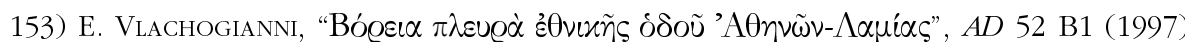
[2002], p. 378-387 [SEG LI 577]: Ed. pr. of an epitaph (marble urn) of a heroised person

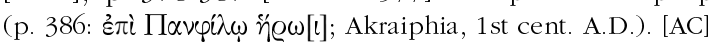

154) R. WACHTER, "Griechisch $\delta o ́ \xi \alpha$ und ein frühes Solonzitat eines Töpfers in Metapont", in M. Fritz - S. ZeILFELDER (edd.), Novalis Indogermanica. Festschrift für Günter Neumann zum 80. Geburtstag, Graz, 2002, p. 497-511 [BE 2003, 648]: After a linguistic analysis of the dedicatory epigram of the potter Nikomachos in Metapontion (CEG 215, c. 525-500 B.C.), W. presents a new translation and interpretation of the text: "I (the clay stele) was made by Nikomachos. Ruler Herakles, have joy on it ( $\chi \alpha i \rho \varepsilon)$. This potter dedicated me to

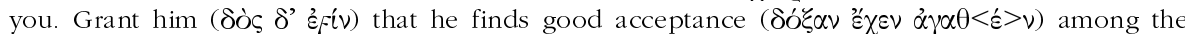
humans". The correspondence between $\chi \alpha \tilde{i} \varrho \varepsilon$ and $\delta$ óc should be interpreted as an example of

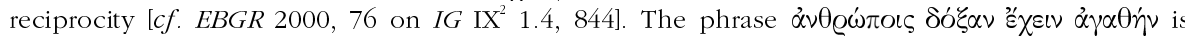
directly inspired by Solon's fr. 13 ed. West/Bergk, and does not originate in a common source. [AC]

155) M.B. Walbank, "Notes on Attic Decrees", ZPE 139 (2002), p. 61-65 [BE 2003, 244] In a brief discussion of eight Athenian decrees, W. presents a new interpretation of $I G \mathrm{II}^{2} 165(=$ $I G \mathrm{II}^{2} 4434$, from the Asklepieion, c. 400-350 B.C.) as an honorific inscription and not part of a dedication. Athena is represented in the surviving part of the relief which crowns the inscription; W. suggests that the missing part showed Asklepios or Demos together with the honorand on a smaller scale (cf. C. LAwTON, Attic Document Reliefs, Oxford, 1995, p. 128 n $^{\circ}$ 98). According to W. an honorary decree (Agora XVI, 239, late 3rd cent.) should not be accociated with the Eleusinian Mysteries, despite the award of myrtle crowns. W. suggests instead that the honorands

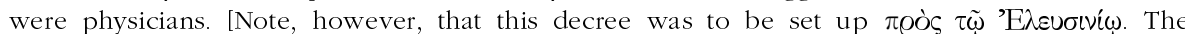
alleged connection between the award of myrtle crowns and the medical use of myrtle is not a very strong argument in favor of this interpretation; see also the critical remarks of Ph. GAUTHIER, BE 2003, 244]. [JM]

156) P. WeIss, "Asiarchen sind Archiereis Asias. Eine Antwort auf S.J. Friesen", in Festschrift Deininger, p. 241-254: A close analysis of inscriptions from Thytteira with the terms

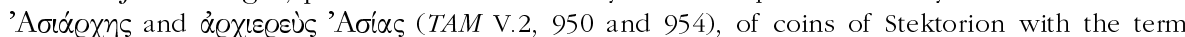

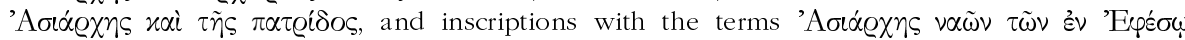

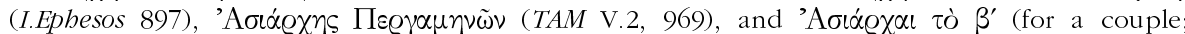

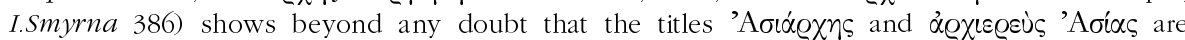
synonyms (cf. Dig. XXVII 1,6,14) [on this controversy see EBGR 1998, 99; 1999, 79 and 181; 2000, 56]. W. suggests that the title Asiarches was introduced in order to express more clearly the high position of the high priest of the provincial emperor cult. [AC]

157) M.H. Williams, "The Case for Jewish Use of Moses as a Personal Name in GraecoRoman Antiquity", ZPE 140 (2002), p. 279-283 [BE 2003, 554]: Continuing the discussion on whether the name Moses was used by Jews as a personal name (EAD., "Jewish Use of Moses as a Personal Name in Graeco-Roman Antiquity - A Note", ZPE 118 [1997], p. 274) or was avoided until the 9th cent. A.D. because of its sacrosanctity (T. DERDA, "Did the Jews use the Name of Moses in Antiquity?", ZPE 115 [1997], p. 257-260; ID., "The Jews and the Name of Moses in Antiquity - A Reply", ZPE 124 [1999], p. 210), W. lists further evidence against the latter view: SEG LI 2082 (Zo'ar in Arabia, 4th cent. A.D.); I.Cret. IV 509 (?, Gortyn, 5th cent. A.D.); CIJ 713 
(Athens, Byzantine), 746 (?Ephesos, 2nd-3rd cent. A.D.), 793 (Korykos, Byzantine), 1420 (?Wadi el-Mukatteb, undated); the papyrus DJD II 91 (?, 2nd cent. A.D.). This evidence shows that Moses was used as a personal name already in the Graeco-Roman world, sometimes in the form Mousaios, Musaeus, and Moussios. [JM]

158) E. Wirbelauer, "Zeus auf Salamis", ZPE 141 (2002), p. 125-128 [BE 2003, 256]: A painting of the Bavarian landscapist Carl Rottmann showing a picturesque Salaminian landscape

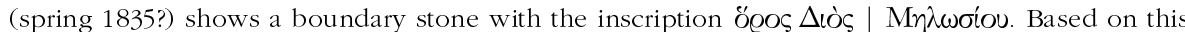
aquarelle W. argues that Zeus Melosios was worshipped on the island of Salamis in the 4th or 3rd cent. B.C. The cult of Zeus Melosios is only known from Naxos (a horos stone: IG XII.5, 48, 4th cent. B.C.) and Korkyra (conical loom weight: $I G$ IX.1, 702, undated). The later object was omitted as a falsum in the corpus of the Ionian Islands ( $G$ IX $1^{2} 4$ ). However, this evidence supports its authenticity. [JM]

159) A. WOLICKI, "The Heralds and the Games in Archaic and Classical Greece", Nikephoros 15 (2002), p. 69-97: Based on literary sources and epigraphic material W. suggests that heralds appeared as participants in competitions for the very first time during the Olympic Games of 396 B.C. Contests of heralds do not appear before the last quarter of the 4 th cent. B.C. in the other three Panhellenic games. As late as the 3rd or 2nd cent. B.C. they appear in other contests (eg. IG IX.2, 525, Larissa, 2nd cent. B.C.; SEG III 368, Chaironeia, 2nd cent. B.C.). An inscription which records victories in the competition of heralds at the Charitesiai of Orchomenos (IG VII 3195) should be dated as late as the 1st cent. B.C. An Athenian account (IG $\mathrm{II}^{2} 16351.68$ 69) does not prove the existence of a herald competitions beyond the Olympic Games, since this text records inter alia benefits for heralds, trumpeters, and assistants in the service of the council of the Delian amphictyony. [JM]

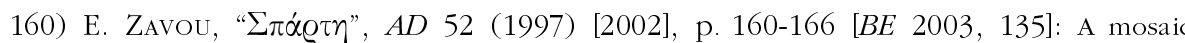
representing Poseidon's triumph was found in Sparta (Late Antiquity). Inscriptions identify the figures as Amphitrite, Proto, Doto, Kymothoe, Speio, and Okeanos. [AC]

\section{Angelos CHANIOTIS}

Seminar für Alte Geschichte und Epigraphik Marstallhof 4

D - 69117 Heidleberg

angelos.chaniotis@urz.uni-heidelberg.de

\section{Jannis MYLONOPOULOS}

Institut für Klassische Archäologie Franz Klein Gasse 1 A-1190 Wien

joannis.mylonopoulos@univie.ac.at 